University of South Carolina

Scholar Commons

Theses and Dissertations

Spring 2020

Geophysical Study of Gold Mineralized Zones in the Carolina Terrane of South Carolina

Saad Saud Alarifi

Follow this and additional works at: https://scholarcommons.sc.edu/etd

Part of the Geological Engineering Commons

Recommended Citation

Alarifi, S. S.(2020). Geophysical Study of Gold Mineralized Zones in the Carolina Terrane of South Carolina. (Doctoral dissertation). Retrieved from https://scholarcommons.sc.edu/etd/5928

This Open Access Dissertation is brought to you by Scholar Commons. It has been accepted for inclusion in Theses and Dissertations by an authorized administrator of Scholar Commons. For more information, please contact digres@mailbox.sc.edu. 


\title{
GEOPHYSICAL STUDY OF GOLD MINERALIZED ZONES IN THE CAROLINA TERRANE OF SOUTH CAROLINA
}

\author{
by \\ Saad Saud Alarifi \\ Bachelor of Science \\ King Saud University, 2010 \\ Master of Science \\ University of South Carolina, 2017
}

Submitted in Partial Fulfillment of the Requirements

For the Degree of Doctor of Philosophy in

Geological Sciences

College of Arts and Sciences

University of South Carolina

2020

Accepted by:

James N. Kellogg, Major Professor

Gene M. Yogodzinski, Committee Member

Scott M. White, Committee Member

Elkhedr H. Ibrahim, Committee Member

Cheryl L. Addy, Vice Provost and Dean of the Graduate School 
(C) Copyright by Saad Saud Alarifi, 2020 All Rights Reserved. 


\section{DEDICATION}

Thanks to almighty God who has given me strength throughout my life to complete this thesis.

This work is dedicated to my wife. Without her unwavering love and support and unyielding patience and understanding this work would have never been completed. I would also like to dedicate this to my child and parents, for their love and support

throughout my life. To the one who laughs my heart by seeing him and hearing his voice, my sun and my moon. 


\section{ACKNOWLEDGEMENTS}

I wish to thank the members of my dissertation committee: James N. Kellogg, Elkhedr H. Ibrahim, Gene M. Yogodzinski, and Scott M. White for generously offering their time, support, guidance and good will throughout the preparation and review of this

document. I would like to especially thank both Dr. James N. Kellogg and Dr. Elkhedr H. Ibrahim for their ongoing supports in their capacities as a mentor and advisor. I would also like to thank Dr. Essam Aboud for his help and advisor. Finally, I would like to thank my friend and monitor Dr. Essam Saied for always keeping my spirits high throughout my studies and for his advisor. I would not have had this opportunity without the full scholarship support from King Saud University. 


\begin{abstract}
The goal of this study was to calibrate and test geophysical methods for the detection of geological structural and disseminated sulfides in the area of the four largest gold deposits in the Southern Appalachian of South Carolina. The Coastal plain sediments, vegetation and saprolite covering the mining areas remain the most challenging in this region. The work focused on the calibration of high-resolution gravity, and helicopter electromagnetic (EM) and magnetic data provided by OceanaGold over the Haile and Brewer Mines; then calibrating the regional gravity and aeromagnetic data over the four gold mines in South Carolina. Observed geophysical fields are correlated with rock properties: resistivities, susceptibilities and mineral concentrations are measured for 40 samples from 16 drill holes, as well as densities and mineral concentrations for 49,183 samples from 448 drill holes in the Haile ore zone. While high resolution potential field data (gravity and magnetics) has not been proven to be effective at small scales in exploration for disseminated sulfides, there is a strong regional correlation between high amplitude gravity and magnetic anomalies and the most productive gold mines in the Carolina terrane. Helicopter EM methods have been shown to be effective in distinguishing sedimentary from volcanic-dominated sediments in the metamorphic rocks of the Carolina terrane. The interpretation of the gravity and magnetic data utilized tilt derivatives, vertical derivative, reduced to pole anomalies (RTP), shaded relief, frequency spectrum, 3-D Euler deconvolution, core drilling and 2-D forward modeling. The most surprising result was that over the Haile Mine, the residual gravity
\end{abstract}


anomalies, tilt derivatives, and vertical derivative show positive anomalies correlated with the location of a disseminated ore body. The gravity field over the ore body can be interpreted as produced by $4 \%$ pyrite and molybdenite. Electromagnetic (EM) anomalies are spatially associated with the Haile ore bodies. The edges of a granite pluton are clearly illuminated by the shaded relief, tilt derivative, and Euler deconvolution of the potential fields. The magnetic fields do not show correlations with the mineralized zones but are instead dominated by granitic and gabbro plutons and northwest trending diabase dikes. The integration and interpretation of the results indicate that metamorphism and hydrothermal alteration destroy magnetite and cause demagnetisation anomalies for the Carolina terrane. East-northeast trending linear anomalies have been sampled and dated as Alleghanian lamprophyre dikes providing the first magnetic map of these intrusions at Haile. Finally, we calculated the probability of detecting a geophysical anomaly of the required minimum dimensions with a given survey spacing over the Haile mine area to reduce the risk of missing the target anomaly. 


\section{TABLE OF CONTENTS}

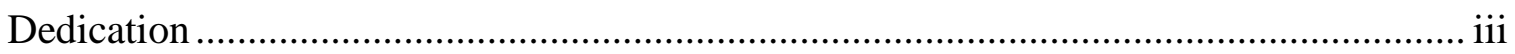

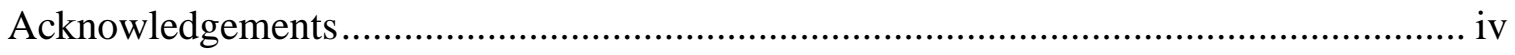

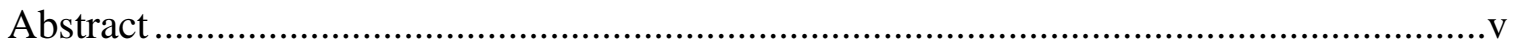

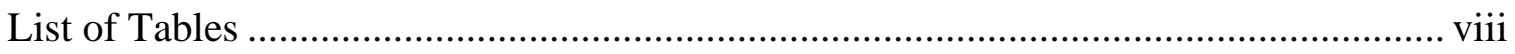

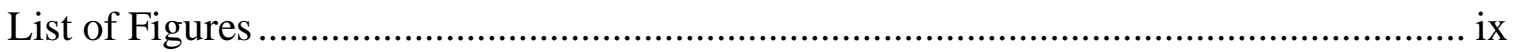

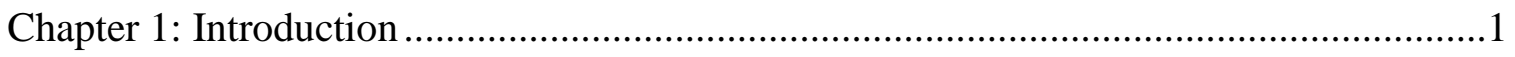

Chapter 2: Gravity, Aeromagnetic and Electromagnetic Study of the Gold and Pyrite Mineralized Zones in the Haile Mine Area, Kershaw, South Carolina.....................12

Chapter 3: Geophysical Study of Gold Mineralized in the Carolina Terrane of South

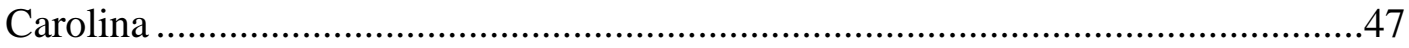

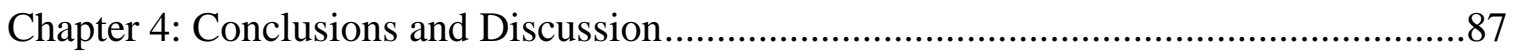

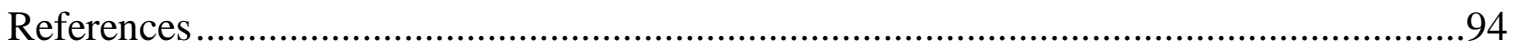

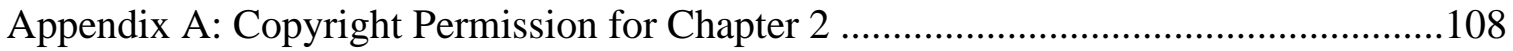




\section{LIST OF TABLES}

Table 2.1 Euler Deconvolution (ED) Structural index (SI) parameter values after Whitehead (2010).

Table 2.2 Density values from OceanaGold laboratory measurements of 5,606 samples

from 60 drill holes in 2016 used for 2D forward models (Figure 2.11)

Table 2.3 Mineral density values after Carmichael (1989) and Telford et al (1990)

Table 3.1 Density values from OceanaGold laboratory measurements of 49,183 samples

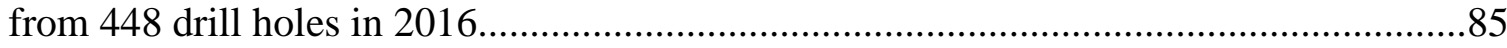

Table 3.2 Ore mineral and host rock densities $\left(\mathrm{g} / \mathrm{cm}^{3}\right)$ and magnetic susceptibilities $\left(10^{-6}\right.$

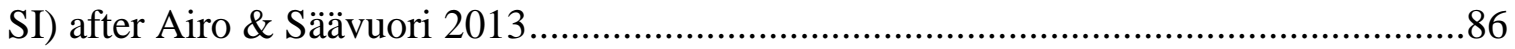

Table 3.3 Resistivity (Ohm-M) measurement values from OceanaGold ........................86

Table 3.4 Magnetic susceptibility (cgs) x $10^{-6}$ measurements from OceanaGold ..............86

Table 4.1 Densities of rocks and minerals (Sharma, 1997) ........................................93 


\section{LIST OF FIGURES}

Figure 2.1 Map of the southeastern United States showing major tectonic terranes in this part of the Appalachian mountain chain after Berry et al. (2016). Five gold mines are shown on this map, the Reed mine in North Carolina (NC), and Brewer, Haile, Ridgeway, and Barite Hill, all located in lower metamorphic rank volcanic arc rocks of the Carolina terrane. Alabama (AL); Delaware (DE); Georgia (GA); Indiana (IN); Maryland (MD); North Carolina (NC); Ohio (OH); South Carolina (SC); Tennessee (TN); Virginia (VA); Washington, D.C. (DC), West Virginia (WV).

Figure 2.2 Geological map of the Haile Mine area after SRK Consulting (2017). A)

Surface geological map. B) Geological bed rock map at $300 \mathrm{ft}(91 \mathrm{~m})$ above sea level. The red polygon outlines the southwest area covered by the helicopter survey. The black lines are A and B profiles after Mobley et al. (2014)

Figure 2.3 A) Location map of gravity stations. Red triangles - OceanaGold stations), black circles - Open-File (Daniels, 2005). B) Bouguer anomaly map showing all gravity stations. C) Helicopter flight lines for magnetic and electromagnetic surveys. D) Total magnetic intensity map. E) EM conductivity map. Black outline is Haile Mine ore body extent. The polygon outlines the southwest area covered by the helicopter survey....

Figure 2.4 A) RTP magnetic anomaly map. B) Grayscale shaded relief image of the RTP magnetic anomaly map. Black outline is Haile Mine ore body extent

Figure 2.5 A) Power spectrum of RTP magnetic map. B) Filtered residual RTP map. C) Power spectrum of Bouguer anomaly map. D) Filtered residual Bouguer anomaly map. Maps $\mathrm{C}$ and $\mathrm{D}$ are produced by applying a Butterworth high pass residual filter with wavelength cutoffs of $0.5 \mathrm{~km}$ and $2 \mathrm{~km}$ respectively. Black outline is Haile Mine ore body extent.

Figure 2.6 A) 1st vertical derivative of RTP map. B) 1st vertical derivative of Bouguer

gravity map. Black outline is Haile Mine ore body extent .

Figure 2.7 A) TDR of filtered RTP magnetic map (Figure 2.5b). B) TDR of filtered Bouguer anomaly map (Figure $2.5 \mathrm{~d}$ ). Black outline is Haile Mine ore body extent

Figure 2.8 A) ED of the TMI magnetic map. Structural Index: 0 (contacts). Depth calculated relative to ground surface. B) ED of Bouguer anomaly map. Elevation above sea level. Structural index: 0 (sill, dike, fault)

Figure 2.9 2-D forward density modeling. Top is profile A. Bottom is profile B. In the middle is a geological map showing metasedimentary units (green) and the two profile 
locations. Gravity station spacing is approximately $100 \mathrm{~m}$. Note that the gravity values are filtered residual anomalies, and the total amplitude of the modelled anomalies is only $0.5 \mathrm{mGal}$ ! Geology after Mobley et al. (2014) and SRK Consulting (2017). Polygon densities are from Table 2.3. Density of saprolite: $2.45 \mathrm{~g} / \mathrm{cc}$, Coastal Plain sediments: 2.6 $\mathrm{g} / \mathrm{cc}$ (James Berry, personal communication, Romarco). Red areas: ore, blue areas: molybdenite, MS: metasedimentary unit, MV: metavolcanic units, SP: saprolite, CP: coastal plain sediments. For geology map see Figure 2.2. $0 \mathrm{~m}$ depth is sea level. No vertical exaggeration: scale is 1:1. (For interpretation of the references to color in this Figure legend, the reader is referred to the web version of this article)

Figure 2.10 A) Average densities of metasedimentary units (MS), gold bearing metasedimentary units (AU) and metavolcanic units (MV) from 49,183 measurements from 448 drill holes (OceanaGold). Number of measurements: MS: 36,061, AU: 31, MV: 13,091. B) Average percentages of pyrite (green) in MS, AU, and MV. C) Sample density vs pyrite \%. D) Correlation coefficient results for minerals and density: pyrite (PY), pyrrhotite (PO)

Figure 2.11 A) geological profile B (location: Figures 2.2b and 2.11) after Mobley et al. (2014). No vertical exaggeration and same scale in all profiles. B) Conductivity inverted for depth along profile B. C) OceanaGold measured core densities from wells along profile B. D) OceanaGold lab estimated pyrite concentrations from drill cores along profile B. Small black box in A and B: boundary of Figures 2.13C and 2.13D. Dashed white line in 2.13A and 2.13B: sea level. Black dashed line at $91 \mathrm{~m}(300 \mathrm{ft})$ above sea level in $2.13 \mathrm{~A}$ is the depth of the bedrock map in Figure 2.2 .........................................4

Figure 2.12 Conductivity map from EM survey. The black polygons in the center are the ore zones from the geological map (Figure 2.2b). A: Sub cropping Richtex Formation metasedimentary units (Figure 2.2b). B: Pageland granite intrusion.

Figure 2.13 RTP magnetic map. A: sub cropping extent of the Ritchtex Formation metasedimentary units (Figure 2.2b). B: Pageland granite intrusion. .46

Figure 3.1 Map of the southeastern United States showing major tectonic terranes after unpublished map (K. Gillon and J. Berry, 2013). Four gold mines are shown on this map, Brewer, Haile, Ridgeway, and Barite Hill, all located in lower metamorphic rank volcanic arc rocks of the Carolina terrane. Alabama (AL); Delaware (DE); Georgia (GA); Maryland (MD); North Carolina (NC); Ohio (OH); South Carolina (SC); Tennessee (TN); Virginia (VA); Washington, D.C. (DC), West Virginia (WV). Red rectangle is the study area location (Figures 3.3 and 3.4).....

Figure 3.2 Geologic map of central South Carolina after Horton and Dicken (2001). Location shown in Figure 3.1. Black rectangles are the study areas. White triangles are gold mine locations same as Figure 3.1: 1) Brewer, 2) Haile, 3) Ridgeway, 4) Barite Hill. Yellow dashed line is the Inner Piedmont (IP) - Charlotte belt (CH) boundary. Red dashed lines are the Carolina terrane (CB) boundaries. Black dashed line is the predicted southeastern boundary of Kiokee high grade metamorphic belt (KB, this paper). 
Figure 3.3 Generalized Stratigraphic column. Ages after Hibbard et al. (2002) ${ }^{1}$; Mobley et al. $(2014)^{2}$; Ayuso et al. $(2005)^{3}$; Dooley and Smith $(1982)^{4}$; Dennis et al. $(1997)^{5}$; Nystrom et al. $(1991)^{6}$.

Figure 3.4 A) Bouguer gravity map of South Carolina study area. See Figure 3.1 for location. See Figure 3.2 for geology. Gravity stations shown as black dots. White triangles are gold mine locations same as Figure 3.1: 1) Brewer, 2) Haile, 3) Ridgeway, 4) Barite Hill. B) Total magnetic intensity (TMI) map. C) TMI with $140^{\circ}$ directional filter. Predicted Modoc shear zone and Kiokee high grade metamorphic belt (this paper).

D) Tilt derivative of magnetic field in gray color....

Figure 3.5 A) Geological bed rock map of Brewer, Haile, and Ridgeway mine area after SRK Consulting (2017) showing predicted Modoc shear zone (this paper). For location see Figures 3.2 and 3.4. B) Bouguer gravity anomaly map. C) High pass filter of Bouguer gravity (wavelength cutoff $=3 \mathrm{~km}$ ). D) Total magnetic intensity. E) High pass filter of magnetic $($ TMI) (wavelength cutoff $=10 \mathrm{~km}) \mathrm{F}$ ) Euler solutions for gravity. Elevation above sea level. Structural index is 0 .

Figure 3.6 A) Geological bed rock map of Barite Hill. See Figures 3.2 and 3.4 for location. B) Bouguer gravity anomaly map. C) High pass filter of gravity (wavelength cutoff $=15 \mathrm{~km}$ ). D) Total magnetic intensity. E) High pass filter of magnetic (TMI) (wavelength cutoff $=10 \mathrm{~km}$ ). F) Euler solutions of gravity. Source elevations above sea level. Structural index is 0 .

Figure 3.7 Brewer mine area. See Figure 3.5a for location. A) Geological bed rock map at $300 \mathrm{ft}(91 \mathrm{~m})$ above sea level (personal communication, John Jory, 2017). B) Bouguer anomaly map showing all gravity stations. Gray triangles - OceanaGold stations, black dots - Open-File stations (Daniels, 2005). C) Filtered residual Bouguer anomaly map (wavelength cutoff $=2 \mathrm{~km}$ ). D) Euler deconvolution of Bouguer anomaly map. Source elevations above sea level. Structural index: 0. E) EM conductivity map. F) Magnetic map. G) Filtered residual magnetic anomaly map (wavelength cutoff $=0.5 \mathrm{~km}$ ).

Figure 3.8 Haile mine area. See Figure 3.5a for location. A) Geological bed rock map at $300 \mathrm{ft}(91 \mathrm{~m})$ above sea level after SRK Consulting (2017). Black line over the ore zone is the profile location for Figure 3.12. B) Bouguer anomaly map showing all gravity stations. C) Total magnetic intensity map. D) EM conductivity map. Black outline is Haile Mine ore body extent.

Figure 3.9 Random wells in Haile mine area. Location same as Figure 8. The polygon outlines the southwest area covered by the helicopter survey. Black dots are drill wells. B) Pyrite percentages inside, east, and south of the Haile ore zone. C) Rock densities $(\mathrm{g} / \mathrm{cm} 3)$ inside, east, and south of the Haile ore zone. Black outline is Haile Mine ore body extent. D) Pink dots are drill wells in the ore zone. Red dots are south of the ore zone. Green dots are east of the ore zone.

Figure 3.10 Average percentages of pyrite in metasedimentary and metavolcanic rocks for 40 samples in Haile ore zone. 
Figure 3.11 Haile mine area low resolution gravity $(\mathrm{A}, \mathrm{B}, \mathrm{C})$ versus high resolution gravity (D, E, F). See Figure 3.5a for location. A, B, and C use only USGS regional gravity observation points. D, E, and F use both the high resolution OceanaGold and the USGS regional gravity observations. Black outline is Haile Mine ore body extent. A) Bouguer gravity anomaly map using low resolution regional USGS gravity. Black line over the ore zone is the profile location for Figure 3.12. B) High pass of regional gravity (wavelength with cutoff $=2 \mathrm{~km}$ ). C) Euler deconvolution solution map for regional data. D) Bouguer gravity anomaly map (USGS plus high resolution OceanaGold). E) High pass of high resolution gravity. F) Euler deconvolution solution map for high resolution gravity observations

Figure 3.12 2-D forward density model for Haile mine profile located in Figure 3.11A after Alarifi et al. (2019). A) Calculated model gravity (solid line from Alarifi et al., 2019), and observed residual gravity at station spacings of $100 \mathrm{~m}$ (black dotted line), 250 $\mathrm{m}$ (red dashed line) and $400 \mathrm{~m}$ (blue dashed line). B) Drill core constrained geology after Mobley et al. (2014) and SRK Consulting (2017). MS (green) is a metasedimentary unit. MV is a metavolcanic unit. AU (red) is gold bearing unit. MO (blue) is molybdenite, SP is saprolite. CP is coastal plain sediments .85 


\section{CHAPTER 1}

\section{INTRODUCTION}

\subsection{Introduction}

This research is primarily focused on using gravity, aeromagnetic, electromagnetic, and core well data in South Carolina. In South Carolina margin, the Coastal Plain sediment, Jurassic rifting, regional plutonic activity and regional metamorphism create a challenging work environment to mapping and delineating the structural and tectonic pattern of Carolina terrane in South Carolina. In subsequent chapters, we address these challenges by integrating a variety of datasets containing gravity, aeromagnetic, electromagnetic, and core well data to provide a better understanding of geology and structure of South Carolina.

This dissertation is divided into four chapters: an introduction, two core chapters, and a concluding chapter. The two core chapters were written as a manuscript for journals. Chapter 2 was submitted to and published in the Journal of Applied Geophysics; Chapter 3 has been submitted to Economic Geology.

The first core chapter, Chapter 2, focuses on newly identified the cause of high gravity residual and high conductivity anomalies over the Haile Mine area and integrated interpretations of 2D gravity, EM, and well core profile across the Haile Mine area of South Carolina. Furthermore, chapter 2 provides a new information discovery on Alleghenian lamprophyre dikes from the first magnetic map in the southeastern United 
States. The chapter also provides an identification and mapping of the rock units in the Haile Mine area. Chapter 3 interprets the regional gravity and magnetic fields over the Carolina slate belt and important gold mine areas by using modern potential field imaging methods, including spectral analysis filtering and Euler deconvolution. Unexposed regional geologic structural features were highlighted and enhanced over the study areas. New resistivities, susceptibilities and mineral concentrations measured for drillhole samples are presented to predict the relative contribution of pyrite to the observed EM, magnetic, and gravity fields. Finally, the station spacing of the gravity survey that is required to see the ore body anomaly were measured over the mineralized zone at the Haile Mine.

\subsection{Geological setting}

The gold mine properties in South Carolina are located in the Carolina Slate belt, part of a volcanic island arc "Carolina terrane" that formed off the coast of Gondwana, hundreds of miles from North America (Laurentia). The slate belt extends from Virginia to Georgia, for more than $500 \mathrm{~km}$ with a maximum width of $140 \mathrm{~km}$ in central North Carolina (e.g., Secor et al., 1983; Horton et al., 1989; Dennis and Wright 1997; Hibbard 2000; Hibbard et al., 2002; Ayuso et al., 2005). The Carolina slate belt contains lowgrade metavolcanics and metasedimentary rocks of Neoproterozoic to Cambrian age 630 to $520 \mathrm{Ma}$ (Secor et al., 1983; Hibbard et al. 2002). Rock type transitions from felsic to mafic submarine volcanics and mudstones to turbidite clastics suggest an intra-arc basin tectonic setting (Ayuso et.al., 2005).

All the gold deposits are hosted in similar geologic settings near the contact between the metamorphosed volcanoclastic (Persimmon Fork Formation) and 
metamorphosed sedimentary rocks (Richtex Formation) of Neoproterozoic to Early Cambrian age (Worthington and Kiff, 1970; SRK Consulting 2017). Near the ore zones the Richtex unit is intensely faulted, hydrothermally altered, and silicified near its contact with the Persimmon Fork unit (Balinsky, 1994; Foley et al., 2001). Most gold deposits in South Carolina are recognized as epithermal, disseminated gold-pyrite deposits that occurred as intra-arc rifting progressed from subaerial to shallow submarine (Feiss et al., 1993; Ayuso et al., 2005; Mobley et al. 2014). The mineralization zones trend ENE subparallel to the Carolina slate belt structure (SRK Consulting 2017).

The gold deposits have ambiguous origins because of the complex geology of the Carolina Slate belt. Several workers have proposed different theories to explain the origin of the gold deposits at the Carolina Slate belts (Worthington and Kiff, 1970; Spence et al., 1980; Worthington et al., 1980; Bell, 1982; Feiss, 1982; Kiff and Spence, 1987; Tomkinson1988; Hayward 1992; Klein et al., 1998; Clark et al., 1999; Foley et al., 2001; Hayward 1992; Ayuso et al., 2005)

Numerous models have been proposed to explain the origin of the gold deposits in the Carolina Slate belt. This debate has been aggravated by coastal plain sediment, saprolite and vegetative cover, very poor exposure of bedrock, metamorphism, deformation, and intense weathering. At the Haile deposit, Tomkson (1988) and Hayward (1992) assigned the mineralization a metamorphic origin (emplaced along regional shear zones and folding) based on structural studies. At Ridgeway deposit, Gillon et al. (1995) proposed a model involving mineralization and remobilization during deformation. Pardee and Park (1948) considered the deposits in the Carolina Slate belt to be graniterelated hydrothermal quartz veins. Worthington and Kiff (1970), Spence et al. (1980), 
and Kiff and Spence (1987) suggested a volcanogenic (syngenetic, marine exhalative) origin. Worthington and Kiff (1970) recognized the deposits at the Brewer, Haile, Ridgeway, and Barite Hill mines as disseminated mineral hosted by intensely altered rocks (argillic, propylitic, and silicic). The gold mineralization at the Haile Mine is hosted within silicified metasediments containing fine grained disseminated pyrite and pyrrhotite and is a replacement type epithermal deposit (Berry et al., 2016). Re-Os ages from molybdenite associated with the mineralization indicate that the deposit formed shortly after major, arc-related volcanic activity (Berry et al., 2016).

The Persimmon Fork Formation consists of felsic to intermediate volcanic rocks. The Persimmon Fork Formation contains albite, chlorite, quartz, biotite, white mica, and epidote. The Richtex Formation is the primary host of gold mineralization and is characterized by thin, alternating bands of sand, silt, and clay. The unmineralized Richtex Formation consists of quartz, calcite, white mica, feldspar, and chlorite (Berry et al., 2016). Gold mineralization at Haile is disseminated and occurs in silicified and pyrite rich metasediments with local K feldspar and molybdenite (SRK Consulting 2017). Mineral zonation is quartz-sericite-pyrite $\pm \mathrm{K}$ feldspar \pm gold $\rightarrow$ sericite \pm pyrrhotite $\rightarrow$ propylitic (chlorite-calcite-epidote) haloes (SRK Consulting 2017). Within the mineralized zones, quartz is dominant, pyrite is moderate, and sericite is variable (SRK Consulting 2017). Moving away from the mineralized zone, quartz and pyrite decrease while sericite increases in abundance (Snider et al., 2014, Hulse et al., 2008). Rocks strike ENE and dip moderately southeast. The Richtex and Persimmon Fork formations are largely covered by Coastal Plain sands (SRK Consulting 2017). 
The Coastal Plain sands developed after splitting of North America "Laurentia" from Africa "Gondwana" and the opening of the Atlantic Ocean during the Mesozoic time. The Coastal Plain is a wedge of sediments that increases in thickness seaward and extends from the Fall line to offshore in the Atlantic Ocean. These Upper Cretaceous to Early Cenozoic sediments reach thicknesses exceeding $4 \mathrm{~km}$ and originate from the subaerial erosion of the Appalachians (Cook et al., 1981, Snipes et al., 1993).

The Carolina terrane recorded four general tectonothermal periods. First, there was a period of folding, foliation and faulting with granite plutonism in Late Neoproterozoic to Early Cambrian (617 to $544 \mathrm{Ma}$ ). Then, a period of upright folding with a penetrative in Late Ordovician-Silurian (457 to $425 \mathrm{Ma}$ ).Then, a period of dextral shear zone that juxtaposed the Carolina and Charlotte terranes in Devonian (393 to 381 Ma); and lastly a period of ductile mylonitic shear zones (e.g., Hyco, Modoc shears) (Hibbard et al., 1998) with orogenic quartz veins and greenschist to amphibolite facies metamorphism and granite plutonism in Late Paleozoic (333 to $286 \mathrm{Ma}$ ), Hibbard et al., 2002; SRK Consulting 2017.

Alleghenian Plutons in the Southern Appalachians show a long intrusive event that formed a NE-trending band of dispersion. These Alleghenian plutons are mostly located in the Carolina and Piedmont terranes and were emplaced during the collision between Laurentia with Gondwana (326 Ma and 288 Ma), Speer et al. 1993.

The Alleghenian (felsic) Plutons contain a coarse-grained hornblende, granodiorite, tonalite, and granite (McSween 1972; Speer et al., 1980; Bell et al., 1980; Speer 1981; McSween et al., 1991). The northwest swarm diabases are exclusively olivine-normative in composition. The diabase dike is having a higher ratio of modal 
titanomagnetite to ilmenite and contain more Fe-rich titanomagnetites (Ragland 1990; Warner and Wasilewski 1990). Accordingly, dike anomalies are most readily apparent where dikes are strongly magnetic and/or they cross nonmagnetic terrain (Daniels and Popenoe 1983). The gabbro rock contains a medium-grained olivine, hornblende, and biotite (McSween et al., 1984; McSween et al., 1991).

\subsection{Methodology}

We used Geosoft Oasis montaj software to process and enhance the potential file databases. The interpretation and analysis of potential field databases was accomplished by applying the following techniques.

\subsubsection{Reduced to pole (RTP)}

Total magnetic intensity map was reduced to magnetic pole filtered to view all magnetic sources produced vertically and symmetrically (Blakely 1995). This tool assumes that lines are relatively rectilinear and calculates the orientation of each line using the first and last point of the line. RTP can be calculated in the wavenumber domain using the following equation,

$$
L(\theta)=\frac{\mathrm{I}}{(\sin I a+i \cos \cdot \cos (D-\theta))^{2}}
$$

Where $\theta$ is the wavenumber direction, $\mathrm{I}$ is the magnetic inclination, $\mathrm{D}$ is the magnetic declination and Ia is the inclination for amplitude correction. Ia is set to an inclination greater than the true inclination of the magnetic field or less than the true inclination in the Southern hemisphere (Macleod et al., 1993).

The RTP filter is applied in the Fourier domain and it moves the observed field from the observation inclination and declination to what the field would look like at the 
magnetic pole. Thus, RTP removes the asymmetries caused by a non-vertical magnetization (Dobrin and Savit, 1988), where the RTP magnetic anomalies are located directly above the source. The RTP algorithm assumes that magnetic responses are magnetized in the direction of the Earth's present day (normal) magnetic field; if remnant magnetization is present, then magnetic anomalies will not be correctly resolved.

\subsubsection{Isolate shallow short wavelength anomalies (Power Spectrum)}

Magnetic and gravity data can be analyzed using techniques that remove the regional magnetic/ gravity from the total magnetic intensity or simple Bouguer gravity anomalies to obtain a residual magnetic/gravity, which is more useful for interpretation. We used fast Fourier transform (FFT) to analyze the potential field data to distinguish residual and regional magnetic sources at different depths. The FFT transformed the grid from space domain into wavenumber domain. Then, it was multiplied by the wavenumber response of the appropriate digital filter. Finally, the transform result of the Fourier coefficients was inverted back into space domain (Hildenbrand 1983; Reeves 2005).

In general, the curves of the power spectrum consist of two parts of linear segments. The first part, which relates to deeper sources, is in the low frequency end where the rate of power decay is linear and can be approximated by a straight line. The second part is in the high frequency end and relates to shallower sources (Spector and Grant 1970; Reeves 2005).

Thus, wavelength filters are used to isolate the deep-seated anomalies from the shallower anomalies. This isolation is based on the assumption that the cutoff wavelength 
of this filter is related to the maximum depth of the source (Dobrin and Savit, 1988; Whitenhead and Musselman 2011).

This methodology is advantageous because it is statistically oriented, averaging source depths over a region containing complex anomalies. Also, as it is based entirely on the analysis of the wavelengths of anomalies, it is less affected by interference due to overlapping anomalies and high-frequency noise than other methods (Hinze et al. 2013).

\subsubsection{Tilt derivative (TDR)}

Tilt derivative method is used to detect the edges of shallow geological sources. Tilt derivative (TDR) or tilt angle, or local phase, was first described by Miller and Singh (1994) and refined by Verduzco et al. (2004) and has been developed by Salem et al. (2007, 2008). TDR is a normalized derivative based on the ratio of the vertical (VDR) and horizontal (THDR) derivatives of the field (Salem et al., 2007). The TDR method assumes that the source structures have buried 2D vertical contacts (Salem et al., 2007, 2008).

The tilt derivative (Miller and Singh, 1994; Verduzco et al., 2004) is defined as $\mathrm{TDR}=\tan -1(\mathrm{VDR} / \mathrm{THDR})$

where VDR and THDR are first vertical and total horizontal derivatives of the total magnetic intensity, respectively.

The tilt derivative ranges between $\pm 90^{\circ}$ or $-\pi / 2$ and $\pi / 2$ (radian) regardless of the amplitude of the vertical derivative or the absolute value of the total horizontal gradient (Salem et al., 2007, 2008). The zero contour of the tilt derivative map can be used to delineate the edges of source bodies, and its negative values are outside the source (Miller and Singh, 1994). 


\subsubsection{Depth estimation (3-D Euler Deconvolution)}

Euler deconvolution is a technique used in the interpretation of potential field data to produce a map that shows the depths and locations of the geologic sources of the magnetic or gravity anomalies observed in a 2D grid. It's an inversion modeling method used to define the location and depth of a source that causes a magnetic or gravity anomaly by examining the rate of change of the potential field as a function of distance for a source of a given geometry (Thompson, 1982; Reid et al., 1990; Whitehead, 2010). The method was developed by Thompson (1982) to interpret a 2D magnetic profile, and extended by Reid et al. (1990) to be applied to gridded data. The apparent depth to the potential field source is derived from Euler's homogeneity equation (Euler deconvolution). This process relates the potential field (magnetic or gravity) and its gradient components to the location of the source of an anomaly, with the degree of homogeneity $\mathrm{N}$ expressed as a "structural index". The structural index (SI) is a measure of the fall off rate of the field with distance from the source (Thompson, 1982; Whitehead 2010). The Euler deconvolution in 3D is given by Reid et al. (1990)

$\left(x-x_{0}\right) d F / d x+\left(y-y_{0}\right) d F / d y+\left(z-z_{0}\right) d F / d z=N(B-T)$

where $(\mathrm{x} 0, \mathrm{y} 0, \mathrm{z} 0)$ is the position of a magnetic source whose total field $\mathrm{T}$ is observed at $(\mathrm{x}, \mathrm{y}, \mathrm{z})$. The total field has a regional value of $\mathrm{B}$ (background value). $\mathrm{N}$ is the structural index (SI), which characterizes the source's geometry. The gradients $\mathrm{dF} / \mathrm{dx}$, $\mathrm{dF} / \mathrm{dy}$ and $\mathrm{dF} / \mathrm{dz}$ are the first derivatives in the direction of $\mathrm{x}, \mathrm{y}$ and $\mathrm{z}$ respectively. The value of the SI parameter depends on the type of source body we are looking for: 0 (contact of infinite depth), 1 (dike), 2 (pipe), and 3 (sphere) (Whitehead, 2010; Reid et al., 1990). 


\subsubsection{First vertical derivative (Edge Detection)}

First vertical derivative is used to enhance the signal related to near-surface geological structures. The first vertical derivative is defined as VDR: $\mathrm{dF} / \mathrm{dz}$, where $\mathrm{dz}$ is first derivative in the direction of $\mathrm{z}$ (Verduzco et al., 2004; Blakely 1995).

Thus, the smaller anomalies are more readily apparent in area of strong regional disturbances. In fact, the first vertical derivative is used to enhance and delineate high frequency features more clearly where they are shadowed by low frequency anomalies.

\subsubsection{Two-dimensional gravity modeling}

Two-dimensional gravity modeling in profile form is beneficial in the calculation of the depth of various features. We used the Geosoft GM-SYS software package to produce 2D forward models. Two-dimensional (2D) models consider the earth in two dimensions, i.e. it changes with depth (the $\mathrm{Z}$ direction) and in the direction of the profile (X direction; perpendicular to strike).

To minimize errors of non-unique solution between the calculated and observed potential fields, the GM-SYS modeling programs require reasonable initial estimates of model parameters such as topography, body shape, depth, magnetization, and density of suspected sources (Mankhemthong et al., 2013). The 2-D modeling program provides a geological evaluation reasonableness model based on any geological and geophysical previous data on the study area. The two-dimensional gravity modeling program is a technique that is based on fitting the gravity parameters with the observed data from a potential field. 


\subsubsection{Directional filter (Strike filtering technique)}

The directional filter helps to exaggerate and enhance trends in some chosen directions. The directional filter can be used to improve the features that have a particular structural trend or direction within a structural province on a map. Such filter is helpful to inhibit the geological noises associated with certain geologic features (Airo et al., 2014; Zahra and Oweis, 2016). The gradient direction counterclockwise from positive X (CCW from $+\mathrm{X})$

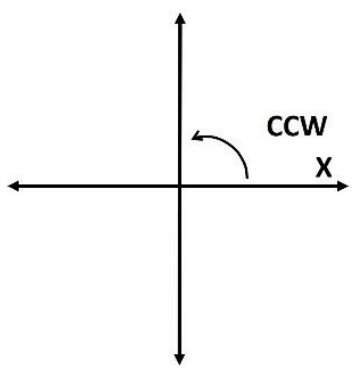




\section{CHAPTER 2}

\section{GRAVITY, AEROMAGNETIC AND ELECTROMAGNETIC STUDY OF THE GOLD AND PYRITE MINERALIZED ZONES IN THE HAILE MINE AREA, KERSHAW, SOUTH CAROLINA ${ }^{1}$}

New high-resolution gravity, electromagnetic (EM) and magnetic data are tested for the detection of disseminated sulfides in the area of the Haile Gold Mine, South Carolina. Geophysical interpretations were constrained with densities and mineral concentrations measured for 49,183 samples from 448 drill holes. Positive residual gravity anomalies from spectral analysis correlate with the mineralized ore zone. Similar correlations between positive anomalies and the ore zones are observed in the first vertical derivative of Bouguer anomaly and tilt derivatives of the residual gravity. Euler deconvolution of the gravity field also shows numerous shallow sources in the ore zone. Drill core measurements show that metasediments (Richtex unit), $(2.76 \mathrm{~g} / \mathrm{cm} 3)$ and gold bearing samples $(2.73 \mathrm{~g} / \mathrm{cm} 3)$ are slightly denser than metavolcanics (Persimmon Fork Formation), (2.69 g/cm3). Correlation coefficients for sample density and mineral percentages show a positive correlation for pyrite (0.18). 2D forward gravity models constrained by dense drilling match the predicted depth range of density anomalies from Euler deconvolution. Drilling results confirm a spatial correlation between high densities,

\footnotetext{
${ }^{1}$ Alarifi, S., Kellogg, J., Elkhedr, I., 2019. Gravity, aeromagnetic and electromagnetic study of the gold and pyrite mineralized zones in the Haile Mine area, Kershaw, South Carolina. Journal of Applied Geophysics, v.164, p. 117-129. Reprinted here with the permission of the publisher. Appendix A
} 
high pyrite concentrations, and the mineralized zones. High conductivity anomalies are observed over the Haile ore zone as well as over the metasediments. Core drilling and 2D inversion show that high conductivity anomalies coincide with zones of high pyrite concentrations. The magnetic field is dominated by anomalies produced by granite plutons $3 \mathrm{~km}$ north and $5 \mathrm{~km}$ west of Haile and northwest-trending Jurassic diabase dikes. East-northeast trending linear anomalies have been sampled and dated as Alleghanian lamprophyre dikes providing the first magnetic map of these intrusions in the southeastern United States.

\subsection{Introduction}

Gold mines at Haile, Ridgeway, Brewer and Barite Hill are all located in the Carolina terrane (Figure 2.1), part of a volcanic island arc that formed off the coast of Gondwana (Hibbard, 2000; Hibbard et al., 2002). The study area (Figure 2.2) is located in the northern part of South Carolina between Kershaw and Jefferson. All the gold deposits in the Carolina terrane are hosted in similar geologic settings near the contact between metamorphosed volcaniclastic and metamorphosed sedimentary rocks of Neoproterozoic to Early Cambrian age (Worthington and Kiff, 1970). The deposit at Haile consists of multiple discontinuous ore bodies with disseminated gold in silicified and pyrite-rich metasediments (Richtex). The ore bodies trend east-northeast, subparallel to the structural trend of the Carolina terrane (SRK Consulting, 2017).

Many studies have suggested that the depositional environment for the Neoproterozoic to Early Cambrian volcaniclastic and sedimentary formations reflected a transition from arc-related subaerial deposition to a rift-dominated collapse of the arc below sea level (Feiss, 1982; Feiss and Vance, 1995). Tomkinson (1988) argued that the 
mineralization at Haile was not syngenetic but was controlled by the development of shear zones. The gold bearing deposits at Haile were affected by regional metamorphism that remobilized and concentrated gold and sulfides in structurally favorable sites (Speer and Maddry, 1993).

In the Haile Mine area in South Carolina, the ore deposits and bedrock geology are covered by a 10 to 40-meter-thick blanket of saprolite, kaolin-rich residuum derived from intense weathering in sub-tropical climates. On top of that, an apron of coastal plain sand, the Cretaceous Middendorf Formation (Nystrom et al., 1991), up to 23 meters thick, covers much of the Haile property (SRK Consulting, 2017). As a result, numerous geophysical surveys, including gravity, airborne magnetic, airborne electromagnetic (EM), and induced polarization/resistivity, have been conducted at Haile to define bedrock geology and locate mineralized zones. In this paper, we will focus on results from gravity, as well as present preliminary results from airborne magnetic and EM surveys.

The gravity method is often integrated with magnetic and electromagnetic methods during integrated base-metal surveys (Telford et al., 1976). Common ore minerals (magnetite, pyrrhotite and pyrite) have densities above $4.0 \mathrm{~g} / \mathrm{cm} 3$, so that their presence can increase the bulk density of a rock (e.g., Airo, 2015). High gravity anomalies are related to high density bodies, whereas low gravity anomalies are related to low density bodies (Hoover et al., 1995). Gravity surveys can play a critical role in the identification of pyrite ore bodies with associated polymetallic massive sulfides, such as in the Iberian pyrite belt of Portugal (Oliveira et al., 1998). In the Iberian pyrite belt, the ore body is hosted by a much less dense volcaniclastic-sedimentary host rock. The large 
density contrast between the massive sulfides and the host rocks contributes to a large gravity anomaly. In Spain, the Las Cruces volcanic massive sulfide deposit, was discovered by a regional gravity survey (McIntosh et al., 1999). The deposit occurs at a depth of approximately $120 \mathrm{~m}$ beneath the Tertiary sediments and is hosted by pyrite belt lithologies that consist of altered felsic to intermediate volcanic rocks with minor sedimentary rocks (McIntosh et al., 1999; Morgan, 2012). In New Zealand, the adulariasericite epithermal gold-silver deposits in the Waihi district, show a positive Bouguer gravity anomaly. These gold-silver deposits consist mostly of andesite-hosted quartz veins and are characterized by alteration haloes of pervasive clay alteration, magnetite destruction, and sulfide mineralization. The epithermal deposits are associated with a striking, enigmatic positive residual gravity anomaly (Morrell et al., 2011). Southwest of Waihi, positive gravity residual anomalies have been identified over the rhyolite hosted Karangahake deposit (Harris et al., 2005). In the Canadian Yukon, the residual gravity anomalies helped detect the Clear Lake massive sulfide deposit. The sulfide minerals are laminated and consist of pyrite, galena and sphalerite (SRK Consulting, 2010). Similar positive residual Bouguer anomalies occur over the Vangorda, Faro and Swim Lake deposits in the Yukon (Ford et al., 2007).

The magnetic method has much in common with the gravity method, but the magnetic field is much more complicated and variable. The magnetic field is bipolar, non-vertical in direction, with sharp local anomaly variations, while the gravity field is unipolar, vertical in direction, with smoother and regional anomalies (Telford et al., 1976). Pyrite is non-magnetic and tends to decrease the rock susceptibility (Airo, 2015). 
Electromagnetic methods have been used quite successfully in the direct detection of massive and disseminated sulfide mineralization, as well as for lithological and structural mapping (Dentith and Mudge, 2014). Helicopter systems have been effective in near-surface mapping, but depth penetration is limited in areas with conductive overburden (Allard, 2007). Electromagnetic resistivity depends on many factors such as porosity, pore conductivity, rock type, the natural fluid and the mineral content of the solid matrix (Airo, 2015). Low resistivity is associated with sulfide minerals, and increased porosity in sericitized rocks, and resistivity highs are associated with silicification and intrusions (Ford et al., 2007).

A helicopter EM and aeromagnetic survey in the Dominican Republic detected anomalies associated with the intermediate sulfidation epithermal style Romero gold deposits with disseminated to semi-massive sulfides (Legault et al., 2016). Low magnetic values over the Romero gold deposits were interpreted to reflect hydrothermal alteration. EM resistivity lows (high conductivity) were also located over the Romero deposits (Legault et al., 2016).

A ground magnetic and low frequency electromagnetic survey at the Haile mine site in the late 1970s located diabase dikes (Wynn and Luce, 1984). Wynn and Luce (1984) indicated that high resistivity responses with silica content. In the late 1980s, induced polarization (IP) and ground magnetic surveys by Piedmont led to the discovery of the Snake ore deposit (Larson and Worthington, 1989). In 2010, an airborne magnetic survey for Romarco Inc., located the diabase dikes and felsic intrusive plutons, but did not distinguish the older units. 
In this paper, we will show that the high-resolution residual gravity anomalies correlate with the ore mineralized zones at Haile and offer a possible explanation for this correlation. We also present preliminary results for magnetic and EM surveys at Haile, including correlations observed between mineralized zones and low resistive anomalies. 2.2 Geological setting

The Carolina terrane extends for more than $500 \mathrm{~km}$ from Virginia to Georgia, with a maximum width of $140 \mathrm{~km}$ in central North Carolina. The Carolina terrane was accreted during the Paleozoic Acadian-Neoacadian orogenic event (Hibbard, 2000; Hibbard et al., 2002). An intrusive magmatic and metamorphic overprint is found mostly in the western portions of the Carolina terrane as a result of oblique accretion with Laurentia, progressing from north to south. The Carolina terrane contains low-grade meta-igneous and metasedimentary rocks of Neoproterozoic to Late Cambrian age (Secor et al., 1983).

In South Carolina, the Carolina terrane consists of a five-kilometer-thick sequence of metasedimentary rocks of the Emory, Richtex, and Asbill Pond formations. These overlie a three-kilometer-thick sequence of metavolcanic rocks, known as the Persimmon Fork Formation (Secor et al., 1983; Hibbard et al., 2002; Secor and Snoke, 2002). The Persimmon Fork Formation is mainly composed of felsic volcanic rocks of rhyodacitic to andesitic composition. The main minerals within this unit are quartz, albite, white mica, chlorite, and biotite deposited in a subaerial environment (Snider et al., 2014). The uppermost one kilometer of the Persimmon Fork Formation contains clastic metasedimentary units that host the ore zones at Haile (SRK Consulting, 2017). The Richtex Formation contains beds of thin metamorphosed siltstones, mudstones, 
wackestones, and turbidite deposits. The main minerals within this unit are quartz, pyrite (generally less than 10 percent), mica (up to 50 percent), pyrrhotite, and chlorite, (Dennis and Wright, 1997; Hibbard et al., 2002; Mobley et al., 2014).

The Persimmon Fork and Richtex formation rocks are dissected by northwesttrending Jurassic diabase dikes and are intruded by Carboniferous granites. Numerous thin (0.1 to $2 \mathrm{~m}$ thick) lamprophyric alkaline dikes are also observed in the Haile area (Mauger, 1988; Maddry and Kilbey, 1995). The lamprophyre dikes contain biotite and plagioclase with chlorite and calcite and are mostly east-northeast trending (SRK Consulting, 2017) with subordinate north- and northeast-striking dikes (Hayward, 1992). Ar40/Ar39 weighted plateau ages from biotite samples yielded early Alleghanian Pennsylvanian ages of approximately $311 \mathrm{Ma}$ (Mobley et al., 2014). These ages are similar to the $314 \pm 2 \mathrm{Ma}$ age of the Dutchman Creek Gabbro that extends $500 \mathrm{~km}$ from North Carolina to Georgia (Mobley et al., 2014). The magnetic images in this paper may provide the first opportunity to map the mafic Alleghanian dikes.

The gold deposits at Haile consists of multiple discontinuous ore bodies. The gold mineralization is disseminated and associated with pyrite, pyrrhotite and molybdenite. The ore bodies trend northeast-southwest and east-northeast, sub-parallel to the trend of the Carolina Terrane. Within the mineralized zones, quartz is dominant, pyrite is lesser ( 0.5 to 3 percent), and sericite is moderate to strong proximal to ore zones. Moving away from the mineralized zone, quartz and pyrite decrease while sericite increases in abundance (Snider et al., 2014, Hulse et al., 2008).

The Haile mine is interpreted as a low sulfide sediment-hosted gold deposit (SRK Consulting, 2017; Nora and Ayuso, 2012). The Re-Os age of mineralization at the Haile 
Mine is $548.7 \pm 2 \mathrm{Ma}$, close to the age of the host rocks at Haile and Ridgeway, $553 \pm 2$ and $556 \pm 2 \mathrm{Ma}$, respectively (Mobley et al., 2014). Haile is interpreted to be a hydrothermal deposit driven by deep-seated magmatism. Thus, the mineralization occurred while the Carolina Terrane was still located in a peri-Gondwana site (Mobley et al., 2014).

Gold mineralization at Haile is mostly hosted by sheared, laminated siltstone and greywacke within 100 meters of the sediment volcanic contact (SRK Consulting, 2017). Structures include minor shearing and structural disruption as well as isoclinal folding and recumbent folds (Secor and Wagener 1968; Secor and Snoke, 1978, 2002; Bell, 1980; Maddry and Kilbey, 1995; Mobley et al., 2014).

\subsection{Data sets and methodology}

High resolution ground gravity data (Figure 2.3a) were collected over the Haile area in 2010 by Romarco (now OceanaGold). The high-resolution land gravity data was merged with the regional gravity data (Daniels, 2005; https://pubs.usgs.gov/of/2005/1022/). In addition, 49,183 density measurements through 448 drill holes were obtained by OceanaGold. An Aeroquest helicopter survey flown for Romarco in 2011 collected high resolution magnetic and time domain electromagnetic data over an area of $48 \mathrm{~km}^{2}$ in the Haile Mine region (Figure 2.3c). The survey was flown with a line spacing of 50 meters over the west block (mine area) and 100 meters over the east block. The control (tie) lines were flown perpendicular to the survey lines with a spacing of 500 meters (west block) and 1,000 meters (east block). The nominal EM bird terrain clearance was 30 meters.

The total magnetic intensity field was reduced to the magnetic pole (RTP) by using the Gx's technique (Phillips, J.D., 2007). The RTP was calculated (Figure 2.4A) 
using the inclination and declination values of $63^{\circ}$ and $-7.20^{\circ}$, respectively. The RTP filter is applied in the Fourier domain and it moves the observed field from the observation inclination and declination to what the field would look like at the magnetic pole. Thus, RTP removes the asymmetries caused by a non-vertical magnetization (Dobrin and Savit 1988), where the RTP magnetic anomalies are located directly above the source. The RTP algorithm assumes that magnetic responses are magnetized in the direction of the Earth's present day (normal) magnetic field; if remnant magnetization is present, then magnetic anomalies will not be correctly resolved. The shaded relief technique is commonly used to enhance the image (Figure 2.4B), highlighting linear structural trends by varying the artificial illumination direction.

2.3.1 Isolate shallow short wavelength anomalies (Power Spectrum)

To separate long (deep) and short (shallow) wavelength potential field anomalies, the cutoff wavelengths and information about the contribution of the short and long wavelengths in the spectrum can be obtained from the calculated radially-averaged power spectrum of the data using fast Fourier transform (FFT) (Spector and Grant, 1970; Bhattacharya, 1965). Spectral analysis of the potential field anomalies indicates an ensemble average depth to different sources of anomalies (Reeves, 2005; Rama Rao et al., 2011; Whitenhead and Musselman, 2011). The power spectrum of the gravity and magnetic fields for the Haile Mine area can be approximated by two linear segments (Figures 2.5a and 2.5c). The low frequency segment relates to deeper sources and the high frequency segment relates to shallower sources. This methodology averages source depths over a region containing complex anomalies and is less affected by interference due to overlapping anomalies and high-frequency noise than other methods (Hinze et al., 
2013). The filtered residual RTP magnetic and Bouguer gravity anomaly maps (Figures $2.5 \mathrm{~b}$ and $2.5 \mathrm{~d}$ ) were produced by applying a Butterworth high pass filter to isolate wavelengths less than $0.5 \mathrm{~km}$ for RTP and less than $2 \mathrm{~km}$ for gravity.

\subsubsection{Edge detection (Tilt and 1st Vertical Derivative).}

To enhance the signal related to near-surface geological structures, the RTP aeromagnetic and Bouguer gravity data were filtered using the first vertical derivative (Figure 2.6). Tilt derivative is another method to detect the edges of shallow geological sources. Figure 2.7 shows the tilt derivatives of the filtered RTP and the filtered gravity maps. Tilt derivative (TDR) or tilt angle, or local phase, was first described by Miller and Singh (1994) and refined by Verduzco et al. (2004) and has been developed by Salem et al. $(2007 ; 2008)$. TDR is a normalized derivative based on the ratio of the vertical (VDR) and horizontal (THDR) derivatives of the field (Salem et al., 2007). The TDR method assumes that the source structures have buried 2D vertical contacts (Salem et al., 2007; 2008). The tilt derivative (Miller and Singh 1994; Verduzco et al., 2004) is defined as $\mathrm{TDR}=\tan -1(V D R / T H D R)$, where VDR and THDR are first vertical and total horizontal derivatives of the total magnetic intensity, respectively. The tilt derivative ranges between $\pm 90 \mathrm{o}$ or $-\pi / 2$ and $\pi / 2$ (radian) regardless of the amplitude of the vertical derivative or the absolute value of the total horizontal gradient (Salem et al., 2007; 2008). The zero contour of the tilt derivative map can be used to delineate the edges of source bodies, and its negative values are outside the source (Miller and Singh 1994).

\subsubsection{Depth estimation (Euler Deconvolution)}

We also used the Euler deconvolution (ED) method to estimate the depth and location of magnetic and gravity sources from the observed field. The method was 
developed by Thompson (1982) to interpret a 2D magnetic profile and extended by Reid et al. (1990) to be applied to gridded data. The 3D Euler deconvolution is based on the Euler's homogeneity equation, an equation that relates the potential field (magnetic or gravity) and its gradient components to the location of the source, with the degree of homogeneity N, interpreted as a structural index. The Euler deconvolution in 3D is given by Reid et al. (1990)

$(x-x 0) d F / d x+(y-y 0) d F / d y+(z-z 0) d F / d z=N(B-T)$

where $(\mathrm{x} 0, \mathrm{y} 0, \mathrm{z} 0)$ is the position of a magnetic source whose total field $\mathrm{T}$ is observed at $(\mathrm{x}, \mathrm{y}, \mathrm{z})$. The total field has a regional value of $\mathrm{B}$ (background value). $\mathrm{N}$ is the structural index (SI). The gradients $\mathrm{dF} / \mathrm{dx}, \mathrm{dF} / \mathrm{dy}$ and $\mathrm{dF} / \mathrm{dz}$ are the first derivatives in the direction of $\mathrm{x}, \mathrm{y}$ and $\mathrm{z}$ respectively. The SI parameter value relies on the source body type and the potential field (Table 2.1; Whitehead, 2010; Reid et al., 1990).

An advantage of the Euler deconvolution method is that it is independent of field direction, dip, or strike of the anomaly feature, so the reduction to pole is unnecessary, as the source positions can be accurately reproduced. In addition, this technique assumes no particular geological model. Euler deconvolution (ED) solutions for the magnetic and gravity fields at the Haile Mine area were calculated using structural index 0 and uncertainties of $10 \%$ and $45 \%$ respectively (Figures $2.8 \mathrm{~A}$ and $2.8 \mathrm{~B}$ ). The number of grid cells in the $\mathrm{x}$ - and y-dimensions, i.e., the window sizes, are 10 and 20 respectively. 2.3.4 Location and source of ore zone density anomalies (2D Forward Models and Drillcore Analysis)

To identify the source of the positive gravity residual anomalies over the Haile ore zone, forward density models were constructed constrained by the extensive drillhole 
sampling available. In addition, the large drillcore database was analyzed to correlate density with mineralogy. 2-D gravity forward models were constructed using Oasis Montaj and 2-D GM-SYS software for two north-south geological sections, A and B, across the ore zone (Figure 2.2). The models were based on previously published geologic profiles (Mobley et al., 2014) and constrained by core drilling to depths of up to 650 meters. Rock densities (Table 2.2) are from 2016 OceanaGold laboratory measurements of 5,606 samples from 60 drillcores using the water immersion method. Other mineral densities values (Table 2.3) were taken from Carmichael (1989) and Telford et al. (1990).

2.3.5 Conductivity-depth imaging of time-domain electromagnetic (TEM) data

Electromagnetic data over the Haile mine area used in this study was collected with a helicopter-borne time-domain electromagnetic system with a concentric horizontal coil configuration. Raw streaming data, sampled at a rate of $36,000 \mathrm{~Hz}$ (120 channels, 300 times per second), was processed with Aeroquest Limited software, pre-filtered, stacked, binned, and split into individual line segments. Conductivity-depth imaging was derived from a pseudolayer half-space model (Palacky, 1981; Huang and Rudd, 2008). Effective depth is derived empirically from the diffusion depth and apparent thickness of the pseudolayer. The pseudolayer technique provides immunity to altimeter errors and better identification and resolution of conductive layers than the homogeneous half-space model. 


\subsection{Results}

2.4.1 Positive density anomalies over ore bodies (Gravity Results)

The Bouguer gravity anomalies in the study area (Figure 2.3b) range from about $6 \mathrm{mGal}$ to $17 \mathrm{mGal}$. The low gravity values correlate well with the Carboniferous Pageland and Liberty Hill granites (Figure 2.2b) because of the granites lower density $(2.63 \mathrm{~g} / \mathrm{cc})$ than the surrounding metamorphic country rock (Table 2.2). Generally higher gravity anomalies in the southern part of the study area are found over Richtex metasediments, and slightly lower anomalies are measured in the central part of the map around the Persimmon Fork metavolcanics (Figures 2.2b and 2.3b). The highest Bouguer anomalies northwest of the mine are related to mafic volcanics. At first, no obvious correlation can be observed between the Bouguer gravity field and the mineralized zone at Haile. However, Euler deconvolution of the Bouguer gravity field (Figure 2.8b) shows a remarkable number of source solutions in the Haile ore zone from 100 meters above sea level to as deep as 500 meters below sea level. To the north, source solutions dip at low angle to the northeast, produced by the south edge of the Pageland granite laccolith (Figure 2.2b and Figure 2.8b).

Spectral analysis of the Bouguer gravity field (Figure 2.5c) distinguishes the long wavelength regional and short wavelength residual components of the field. The regional component reflects a depth range of 1.5 to $5.7 \mathrm{~km}$ and an average depth of $4 \mathrm{~km}$ (Figure 2.5c). The high frequency residual components represent a depth range of 10 to $900 \mathrm{~m}$ and an average depth about $290 \mathrm{~m}$. The entire amplitude range of the filtered residual gravity anomaly map (Figure $2.5 \mathrm{~d}$ ) is less than $0.5 \mathrm{mGal}$, so a high precision densely spaced ground gravity survey was required to achieve this resolution (Figure 2.3a). The 
residual gravity anomaly map (Figure $2.5 \mathrm{~d}$ ) shows a correlation between positive residual anomalies and the mineralized ore zone in the Haile mine area (also compare to bedrock geology in Figure 2.2b). The lowest residual anomalies (Figure 2.5d) are found over the Persimmon Fork metavolcanics (Figure 2.2b). The tilt derivative (TDR) map of residual gravity (Figure 2.7b) shows a similar correlation between positive anomalies and the ore zone.

The vertical derivatives enhance shallow features and are responsive to local fluctuations in the gravity field. High frequency anomalies are observed surrounding the ore bodies in the 1st vertical derivative of gravity field (Figure 2.6b), and the edge detection appears comparable to the high pass filtered residual (Figure 2.5d) and slightly better than the TDR anomalies. However, these high frequency vertical derivative anomalies may contain artifacts of the denser gravity observation spacing around the ore deposits (Figure 2.3a).

2.4.1.1 Pyrite ore zone density anomalies (Forward Modeling and Drillcore Analysis)

Two-dimensional forward gravity models were generated along two profiles with known geology from multiple drill cores to test whether the short wavelength residual gravity could be correlated with rock units and mineralized zones (Figure 2.9), and hence whether high resolution gravity could be useful as an exploratory tool. The geology is after Mobley et al. (2014), SRK Consulting (2017), and numerous drill cores (OceanaGold). Unit densities for the 2D forward models are from OceanaGold laboratory measurements of 5,606 samples from 60 drill holes (Table 2.2). The amplitude of the measured surface residual anomalies is only $0.5 \mathrm{mGal}$, and the model is sensitive to the measured thicknesses of the saprolite and Coastal Plain sediments. The dense 
drillcore sampling tightly constrained the geology along the profile with high confidence and therefore was used as the input for our initial 2D polygon model. Because of uncertainties in average rock densities, we were prepared to vary the polygon densities to fit the observed gravity. Remarkably, we did not have to modify the drill core based polygon geometries or the unit densities to fit the observed residual gravity anomalies in both profiles, despite the small amplitude of the residual signal $(0.5 \mathrm{mGal})$ and the small density difference between the metavolcanics and metasediments $(0.06-0.07 \mathrm{~g} / \mathrm{cc})$. This gives us a high level of confidence in the forward density model. The only required modification to fit the observed gravity was the steeply south-dipping metavolcanicmetasediment contact on the south (right) end of both profiles (Figure 2.9) which had not been sampled with the drillcores. The predicted depths of the source bodies for density anomalies are in agreement with the depth range of solutions from Euler deconvolution of the Bouguer field in the ore zone (Figure 2.8b) of 130 meters above sea level to 500 meters below sea level.

Why are the metasediments and gold-bearing rocks denser than the metavolcanics? Densities were measured and mineral concentrations visually assessed for 49,183 samples from 448 drill holes in the Haile Mine area (Figure 2.10) from OceanaGold 2016 drilling as well as from previous drilling by Romarco. The measurements included 36,061 metasediments, 13,091 metavolcanics, and 31 goldbearing samples. The average densities (Figure 2.10a) are metasediments: $2.76 \mathrm{~g} / \mathrm{cm} 3$, metavolcanics: $2.69 \mathrm{~g} / \mathrm{cm} 3$, and gold bearing samples: $2.73 \mathrm{~g} / \mathrm{cm} 3$. Figure $2.10 \mathrm{~b}$ shows that the average concentration of pyrite in the gold-bearing rocks is $1.5 \%$, in metasediments: $1.1 \%$, and metavolcanics: only about $0.25 \%$. A scatter plot (Figure $2.10 \mathrm{c}$ ) 
also shows that density and $\%$ pyrite have a positive linear correlation: density $(\mathrm{g} / \mathrm{cc})=$ $2.73+0.014$ (\% pyrite). Figure 2.10d shows the correlation coefficients for sample density and mineral percentages for pyrite and pyrrhotite. The density correlation for pyrite is 0.18 , indicating a positive correlation.

Figure 2.11 shows drilling results along profile B. The geology after Mobley et al. (2014) (Figure 2.11a) is compared to the core sample densities (Figure 2.11c) and the laboratory estimated pyrite concentrations (Figure 2.11d). The drilling results (Figure 2.11) show a spatial correlation between high densities, high pyrite concentrations, and the mineralized zones.

Airo and Mertanen (2008) noted that rock densities tend to increase as the abundance of sulfides increases, and Airo (2015) pointed out that the densities of common ore minerals are all above $4.0 \mathrm{~g} / \mathrm{cm} 3$, so that their presence increases the bulk density of rock. Of the common ore minerals, magnetite, pyrrhotite and pyrite all have densities $\sim 5 \mathrm{~g} / \mathrm{cm} 3$.

2.4.2 Conductivity anomalies over the ore zone (EM Results)

Figure 2.12 shows the raw conductivity map at the bird altitude of $30 \mathrm{~m}$. The map shows high conductivity anomalies over the Haile ore zone as well as over the Richtex metasediments (A). Low conductivity is observed over the Pageland granite outcrops (B, Figure 2.12). In Figure $2.11 \mathrm{~b}$ the conductivity is inverted for depth. Note that a high conductivity anomaly correlates with the position of the main ore zone. Cultural anomalies, such as power lines and water lines can create artifacts in EM maps. Alarifi (2017) showed that filtering can reduce the signal from cultural anomalies in the EM data. We do not have conductivity measurements on samples from the Haile Mine area, 
so we are unable to conclusively determine the source of the EM anomalies. However, we note from core drilling along profile B that high conductivity anomalies coincide with zones of high pyrite concentrations (Figure 2.11d). Conduction is largely electrolytic, and conductivity depends upon porosity, hydraulic permeability, moisture content, concentration of dissolved electrolytes, temperature and phase of pore fluid (Airo, 2015). Massive sulfides in general and pyrite have low resistivities (Airo, 2015 and Ford et al., 2007) and may contribute to the high conductivity in the ore zones. The metasediments also have a high pyrite concentration (Figure 2.10b), while granites are low in pyrite and generally exhibit high resistivity.

2.4.3 Jurassic diabase and Alleghanian lamprophyre dikes (Magnetic Results)

Unlike the EM and residual gravity fields, there is no apparent correlation between the magnetic field and the ore bearing zones. Total Magnetic Intensity (TMI) anomalies in the map area (Figure 2.3d) range from 50,050 to 50,440 nT. The highest value, about 50,444 nT, is located in the northeast part of the map area over the Pageland granite (felsic intrusion). In general, the Reduced to Pole map (Figures 2.4 and 2.13) shows only minor differences from the total magnetic intensity map (Figure 2.3d). The 2dimensional power spectrum of the RTP map (Figure 2.5a) shows a distinct high frequency residual component of the magnetic field with an average depth of 250 meters. The magnetic map (Figure 2.3d, Figure 2.4, and Figure 2.13) is dominated by anomalies produced by the Pageland granite intrusion and NW-SE trending diabase dikes. The Richtex metasediments (A in Figure 2.13) are relatively non-magnetic. The shaded relief image of the RTP magnetic map (Figure 2.4b) highlights linear features in the maps. In particular, the shaded relief map illuminates the Pageland granite contact. 
The relief map (Figure 2.4b) also shows the NW-SE trending diabase dikes. However, in addition the shaded relief map also illuminates a series of ENE-WSW trending linear anomalies. One of these anomalies appears to spatially correlate with an ENE-WSW trending lamprophyre dike mapped in the Haile ore zone by Hayward (1992). Ar40/Ar39 weighted plateau ages from biotite samples yielded early Alleghanian Pennsylvanian ages of approximately $311 \mathrm{Ma}$ (Mobley et al., 2014). These ages are similar to the $314 \pm 2 \mathrm{Ma}$ age of the Dutchman Creek Gabbro that extends $500 \mathrm{~km}$ from North Carolina to Georgia (Mobley et al., 2014). The magnetic maps presented in this paper may be the first for the Alleghanian age lamprophyre dikes in the southeastern US. The Alleghanian dikes are also visible on the 1st vertical derivative of RTP map (Figure 2.6a) and a little less visible on the tilt derivative (TDR) of residual RTP map (Figure 2.7a). The ENE-WSW trending dikes are also apparent as shallow ( 0 - 100 meters $)$ magnetic source bodies in the Euler Deconvolution map (Figure 2.8a).

\subsection{Conclusions}

1) Following spectral analysis, the filtered residual Bouguer gravity anomaly map shows a correlation between positive anomalies and the mineralized ore zone in the Haile mine area. The entire amplitude range of the residual gravity anomaly map is less than $0.5 \mathrm{mGal}$, so a high precision densely spaced ground gravity survey was required to achieve this resolution. Similar correlations between positive anomalies and the ore zones are observed in the first vertical derivatives of Bouguer gravity and tilt derivatives of the filtered residual gravity. 
2) Euler deconvolution of the Bouguer gravity field shows a remarkable number of source solutions in the Haile ore zone in the depth range from $130 \mathrm{~m}$ above sea level to $500 \mathrm{~m}$ below sea level.

3) Densities and mineral concentrations from drillcores show that correlation coefficients for sample density and mineral percentages are pyrite (0.18) and pyrrhotite (0.08), indicating that pyrite is the main mineral increasing sample density.

4) 2D forward gravity models constrained by dense drill coring match the predicted depth range of density anomalies from Euler deconvolution. The models are sensitive to the measured thicknesses of the saprolite and Coastal Plain sediments. The drilling results confirm a spatial correlation between high densities, high pyrite concentrations, and the mineralized zones.

5) High electromagnetic conductivity anomalies are observed over the Haile ore zone as well as over the Richtex metasediments. Filtering reduces cultural signals and increases confidence in the correlation. Core drilling and 2D inversion show that high conductivity anomalies coincide with zones of high pyrite concentrations.

6) The magnetic field is dominated by anomalies produced by the Pageland granite intrusion and NW-SE trending diabase dikes. Richtex metasediments are relatively nonmagnetic. The shaded relief map illuminates a series of ENE-WSW trending linear anomalies that have been dated as Alleghanian age lamprophyre dikes.

High precision gravity methods appear to be useful tools for future exploration for sediment-hosted ore bodies with disseminated gold in silicified and pyrite-rich metasediments in the Carolina terrane. Further sampling and testing will be needed to correlate electromagnetic conductivity anomalies with the mineralogy in the ore zone. 
Table 2.1: Euler Deconvolution (ED) Structural index (SI) parameter values after Whitehead (2010)

\begin{tabular}{l|l|l}
\hline SI & MAGNETIC FIELD & GRAVITY FIELD \\
\hline $\mathbf{0 . 0}$ & contact & sill/dyke/step \\
$\mathbf{0 . 5}$ & thick step & ribbon \\
$\mathbf{1 . 0}$ & sill/dyke & pipe \\
$\mathbf{2 . 0}$ & pipe & sphere \\
$\mathbf{3 . 0}$ & sphere & \\
\hline
\end{tabular}

Table 2.2: Density values from OceanaGold laboratory measurements of 5,606 samples from 60 drill holes in 2016 used for 2D forward models (Figure 2.11)

\begin{tabular}{|c|c|c|}
\hline UNIT & Count & Average Density (g/cm3) \\
\hline Saprolite & 49 & 2.45 \\
\hline Visible gold-bearing rock $(\mathrm{Au})$ & 9 & 2.74 \\
\hline Metavolcanic (MV) & 1916 & 2.74 \\
\hline Metasediments (MS) & 3388 & 2.81 \\
\hline Diabase dike & 123 & 2.88 \\
\hline
\end{tabular}

Table 2.3: Mineral density values after Carmichael (1989) and Telford et al (1990)

\begin{tabular}{|c|c|}
\hline Minerals & Density \\
\hline Pyrite & $4.9 \mathrm{~g} / \mathrm{cc}$ to $5.1 \mathrm{~g} / \mathrm{cc}$ \\
\hline Gold & $15.6 \mathrm{~g} / \mathrm{cc}$ to $19.3 \mathrm{~g} / \mathrm{cc}$ \\
\hline Molybdenite & $4.4 \mathrm{~g} / \mathrm{cc}$ to $4.99 \mathrm{~g} / \mathrm{cc}$ \\
\hline
\end{tabular}




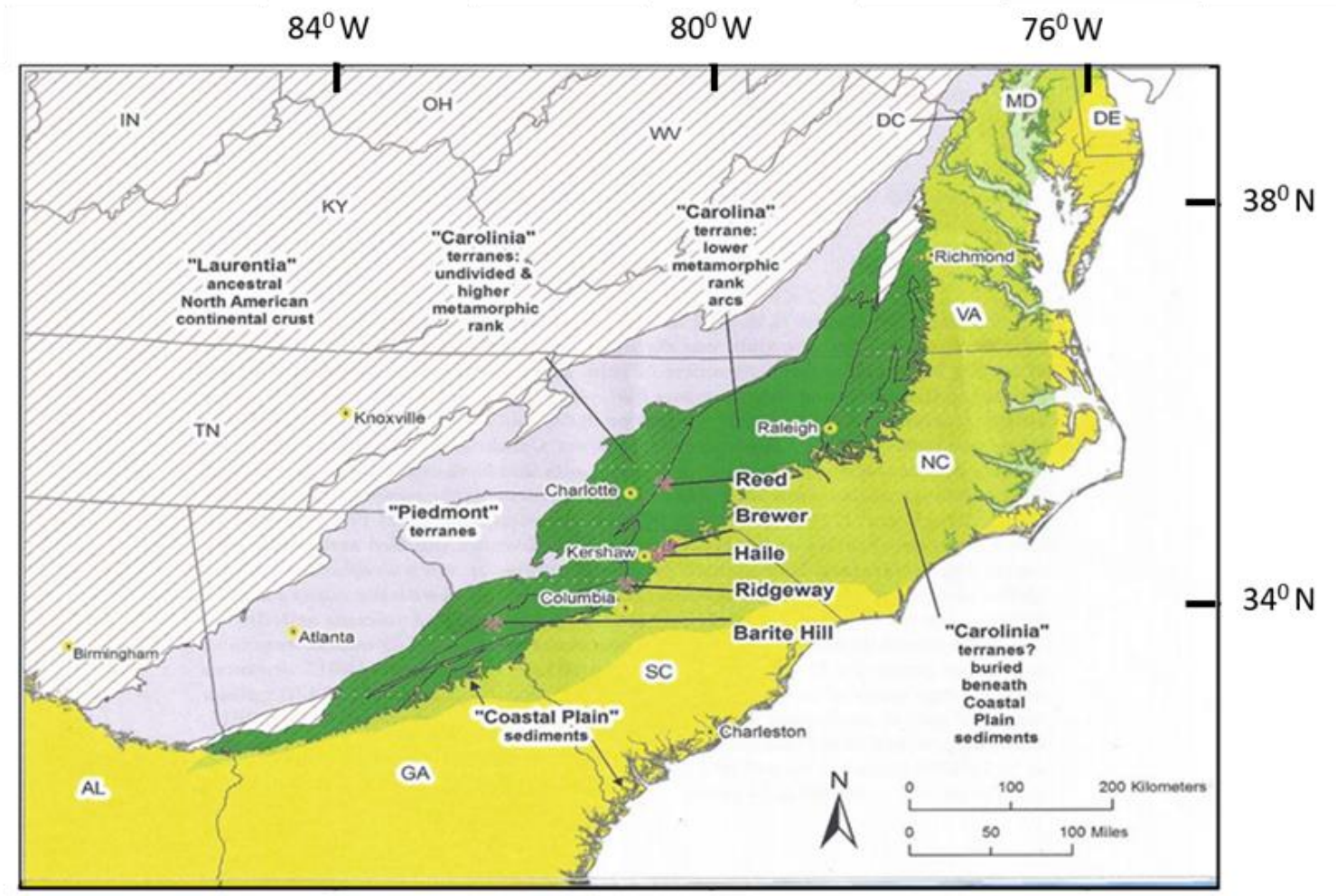

Figure 2.1: Map of the southeastern United States showing major tectonic terranes in this part of the Appalachian mountain chain after Berry et al. (2016). Five gold mines are shown on this map, the Reed mine in North Carolina (NC), and Brewer, Haile, Ridgeway, and Barite Hill, all located in lower metamorphic rank volcanic arc rocks of the Carolina terrane. Alabama (AL); Delaware (DE); Georgia (GA); Indiana (IN); Maryland (MD); North Carolina (NC); Ohio (OH); South Carolina (SC); Tennessee (TN); Virginia (VA); Washington, D.C. (DC), West Virginia (WV). 

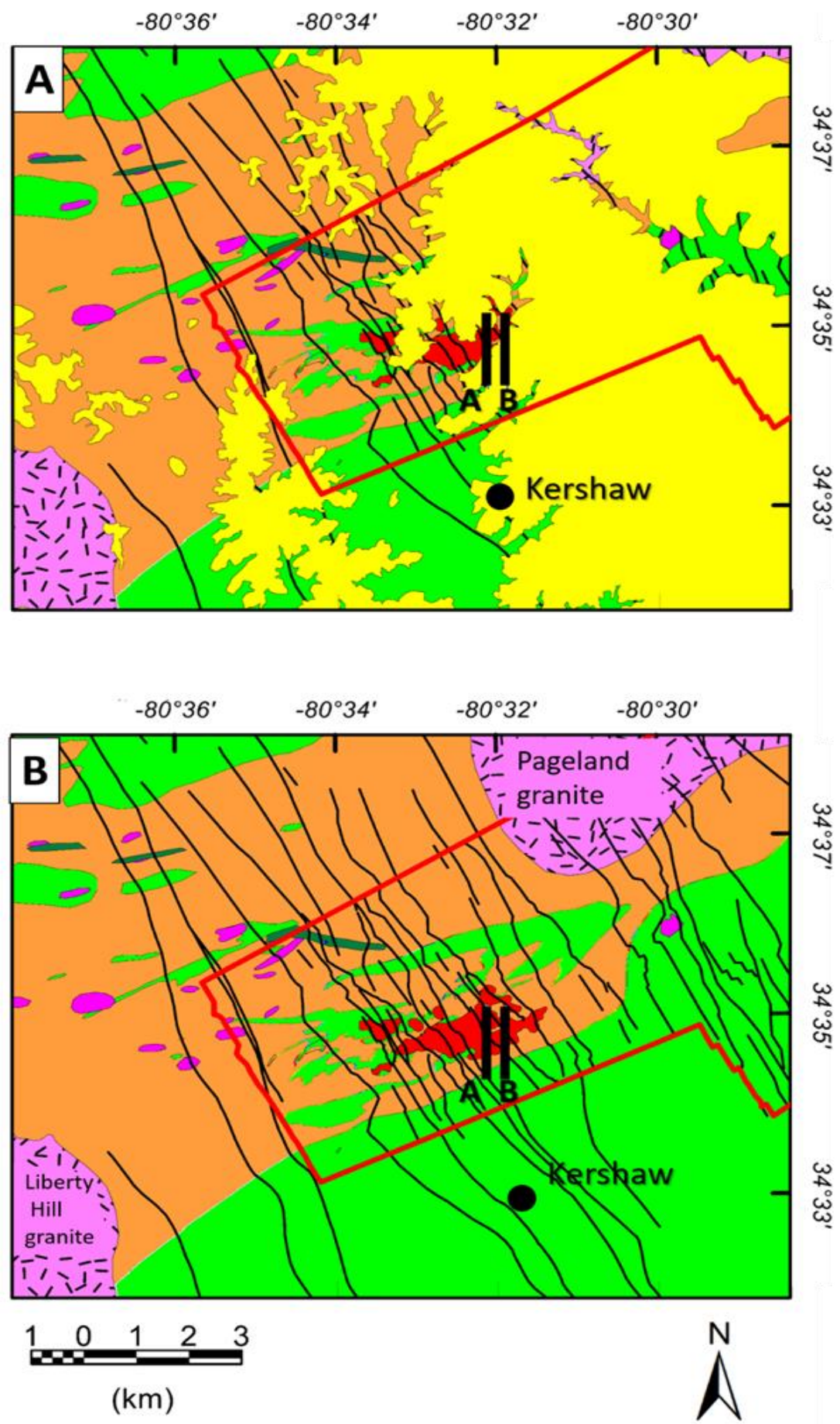

\section{Metasedimentary Intermediate-felsic metavolcanics Ore body}

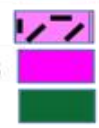

Felsic intrusive

Au bearing alteration Mafic to interm. volcanic

Coastal Plain

Diabase dikes

Figure 2.2: Geological map of the Haile Mine area after SRK Consulting (2017). A) Surface geological map. B) Geological bed rock map at $300 \mathrm{ft}(91 \mathrm{~m})$ above sea level. The red polygon outlines the southwest area covered by the helicopter survey. The black lines are A and B profiles after Mobley et al. (2014). 


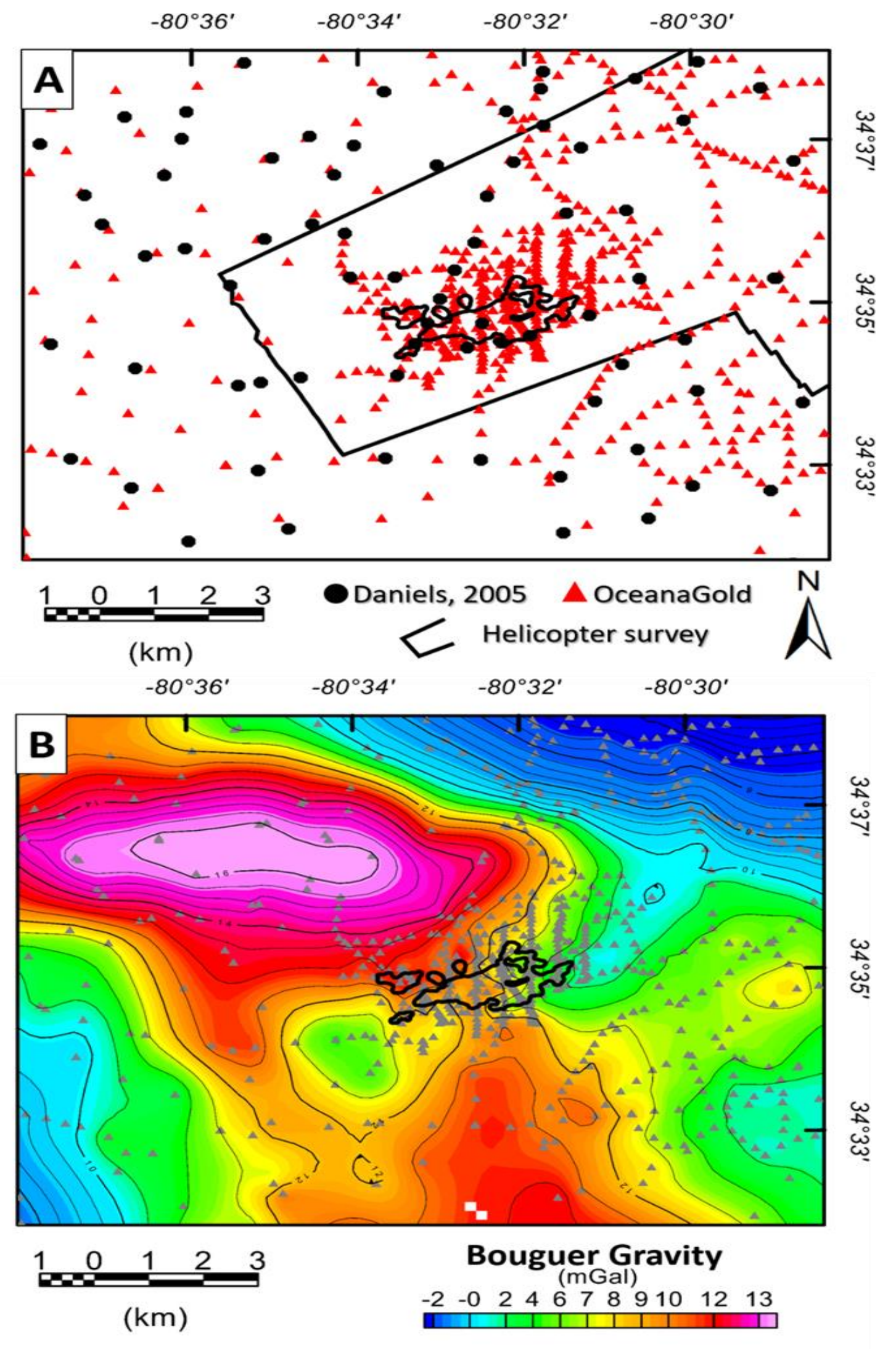



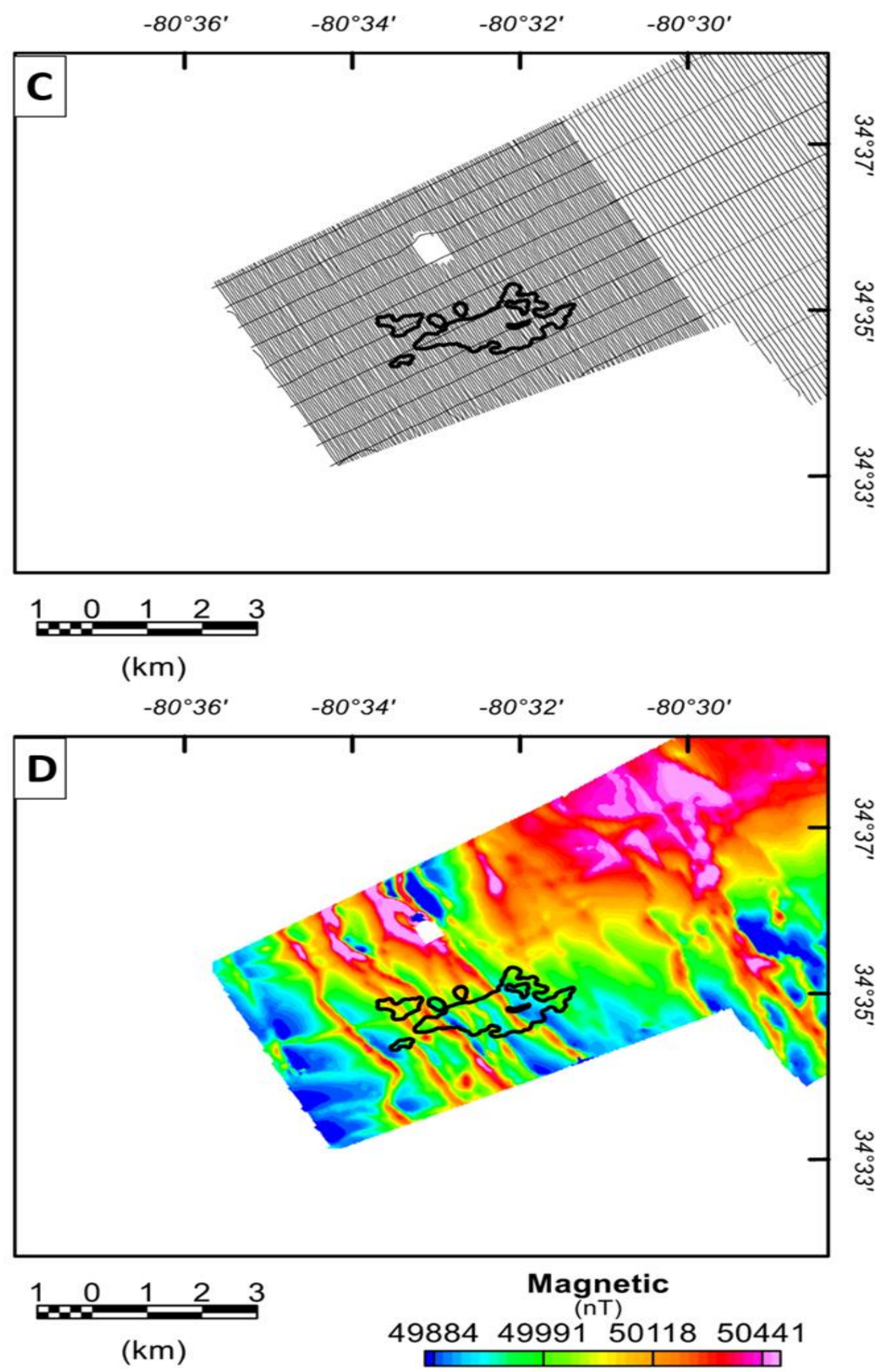


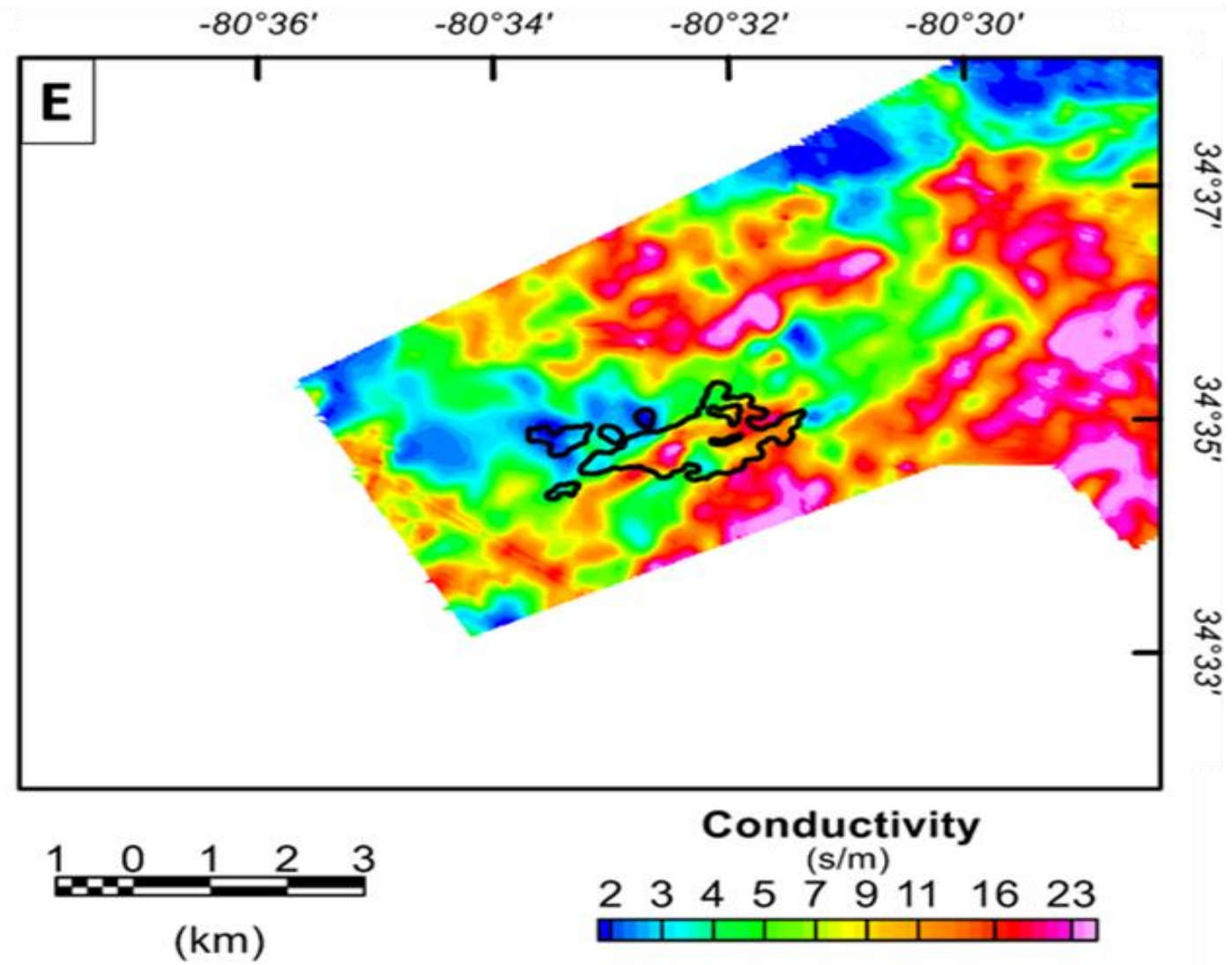

Figure 2.3: A) Location map of gravity stations. Red triangles -OceanaGold stations), black circles - Open-File (Daniels, 2005). B) Bouguer anomaly map showing all gravity stations. C) Helicopter flight lines for magnetic and electromagnetic surveys. D) Total magnetic intensity map. E) EM conductivity map. Black outline is Haile Mine ore body extent. The polygon outlines the southwest area covered by the helicopter survey. 


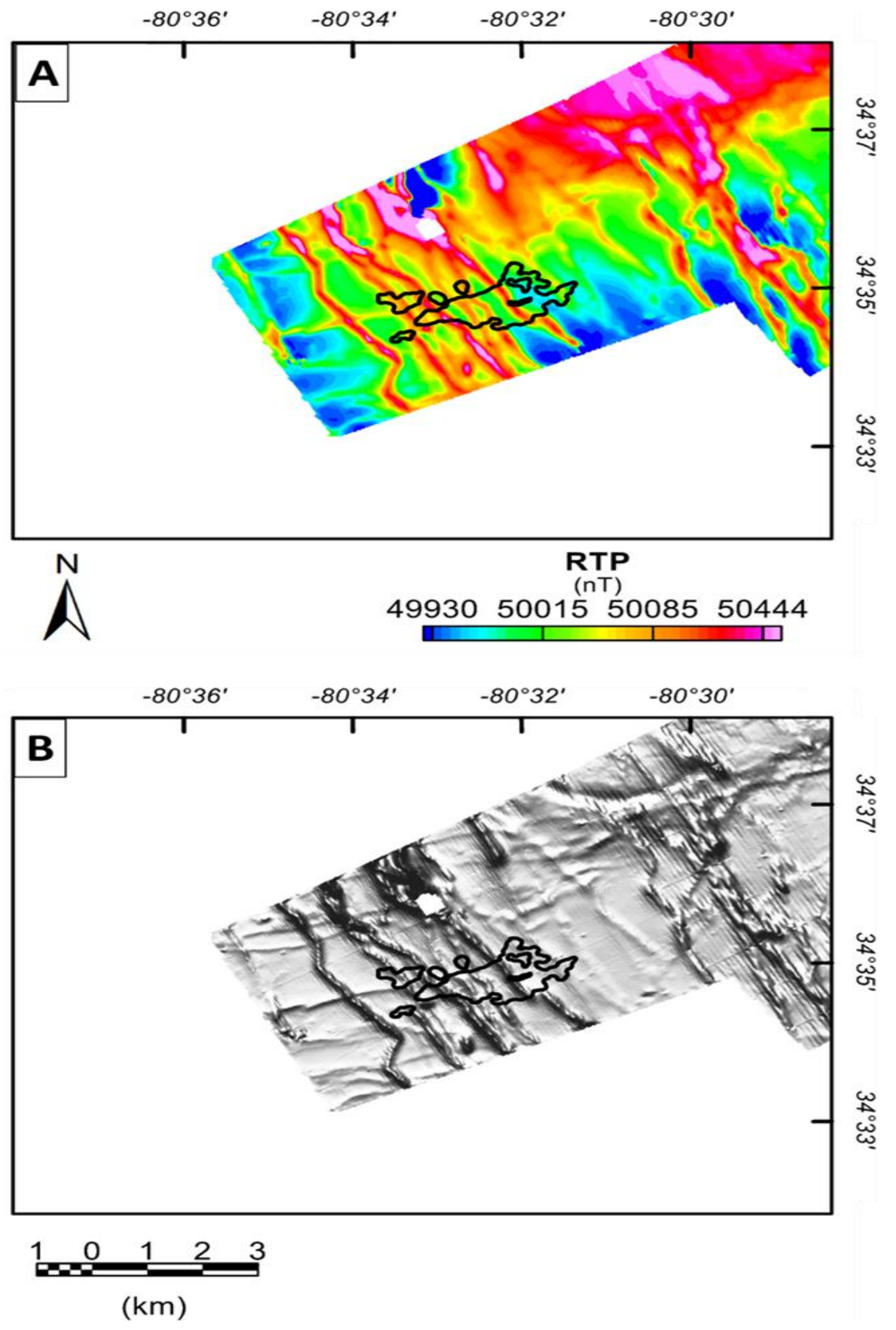

Figure 2.4: A) RTP magnetic anomaly map. B) Grayscale shaded relief image of the RTP magnetic anomaly map. Black outline is Haile Mine ore body extent. 

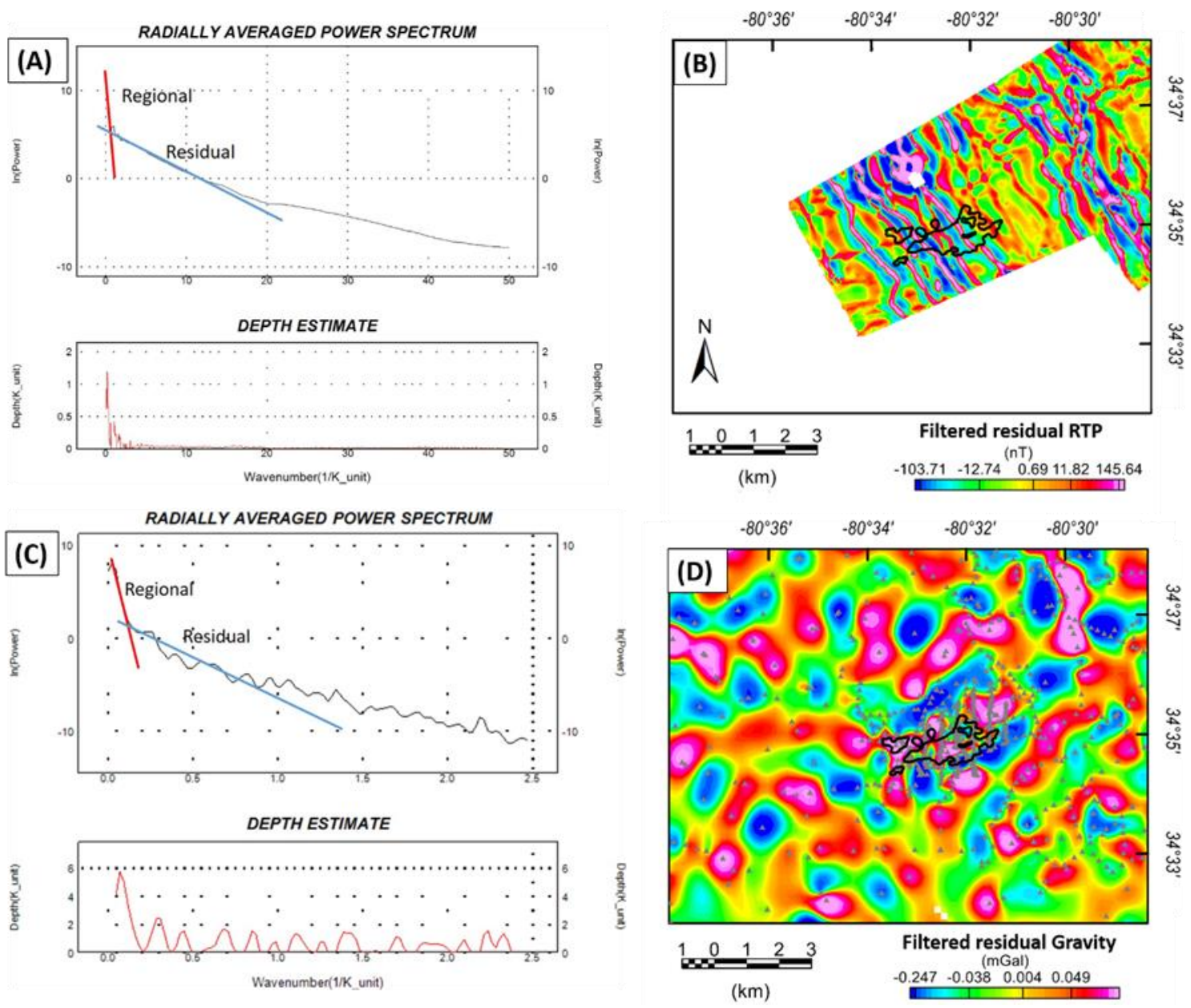

Figure 2.5: A) Power spectrum of RTP magnetic map. B) Filtered residual RTP map. C) Power spectrum of Bouguer anomaly map. D) Filtered residual Bouguer anomaly map. Maps $\mathrm{C}$ and $\mathrm{D}$ are produced by applying a Butterworth high pass residual filter with wavelength cutoffs of $0.5 \mathrm{~km}$ and $2 \mathrm{~km}$ respectively. Black outline is Haile Mine ore body extent. 

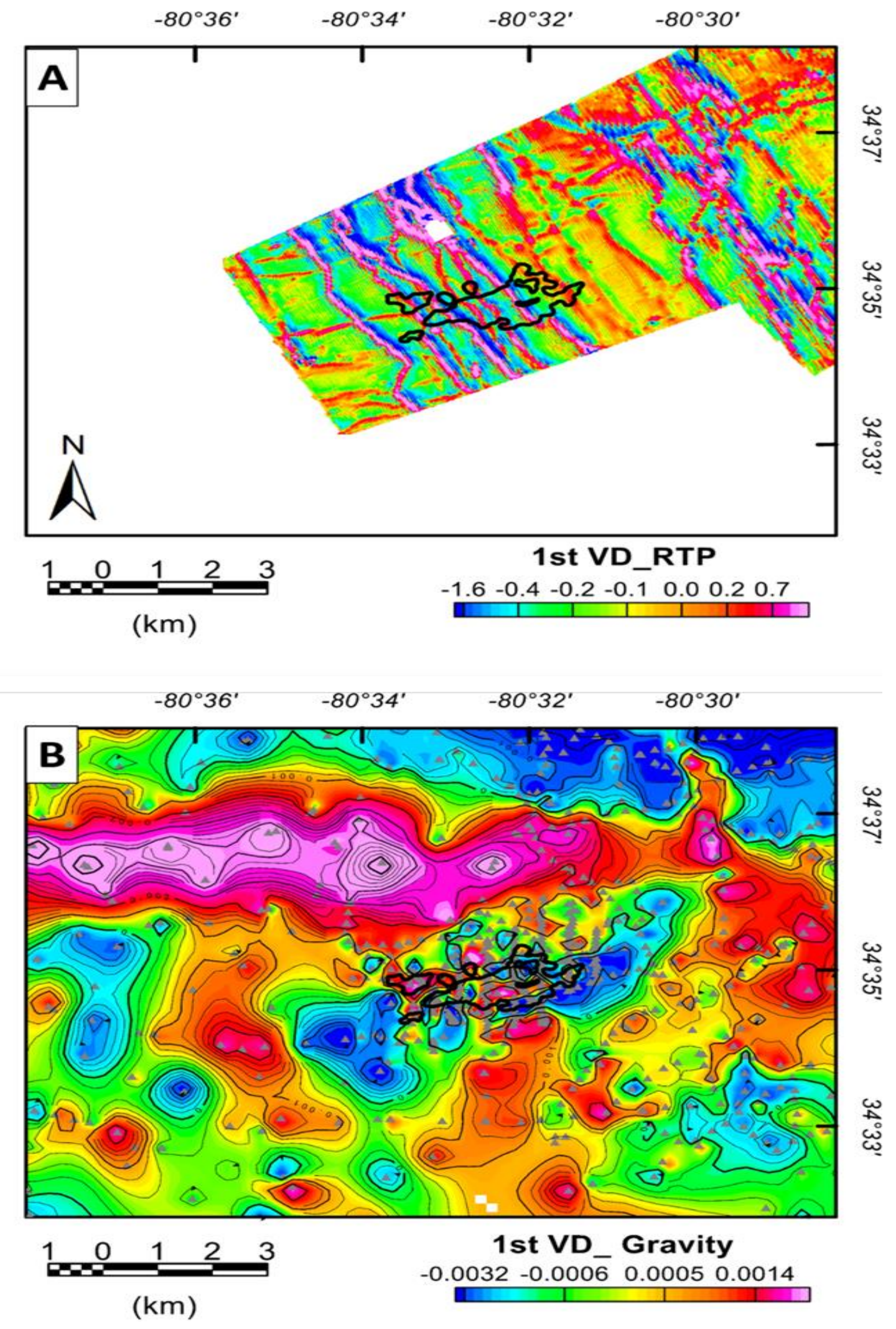

Figure 2.6: A) 1st vertical derivative of RTP map. B) 1st vertical derivative of Bouguer gravity map. Black outline is Haile Mine ore body extent. 

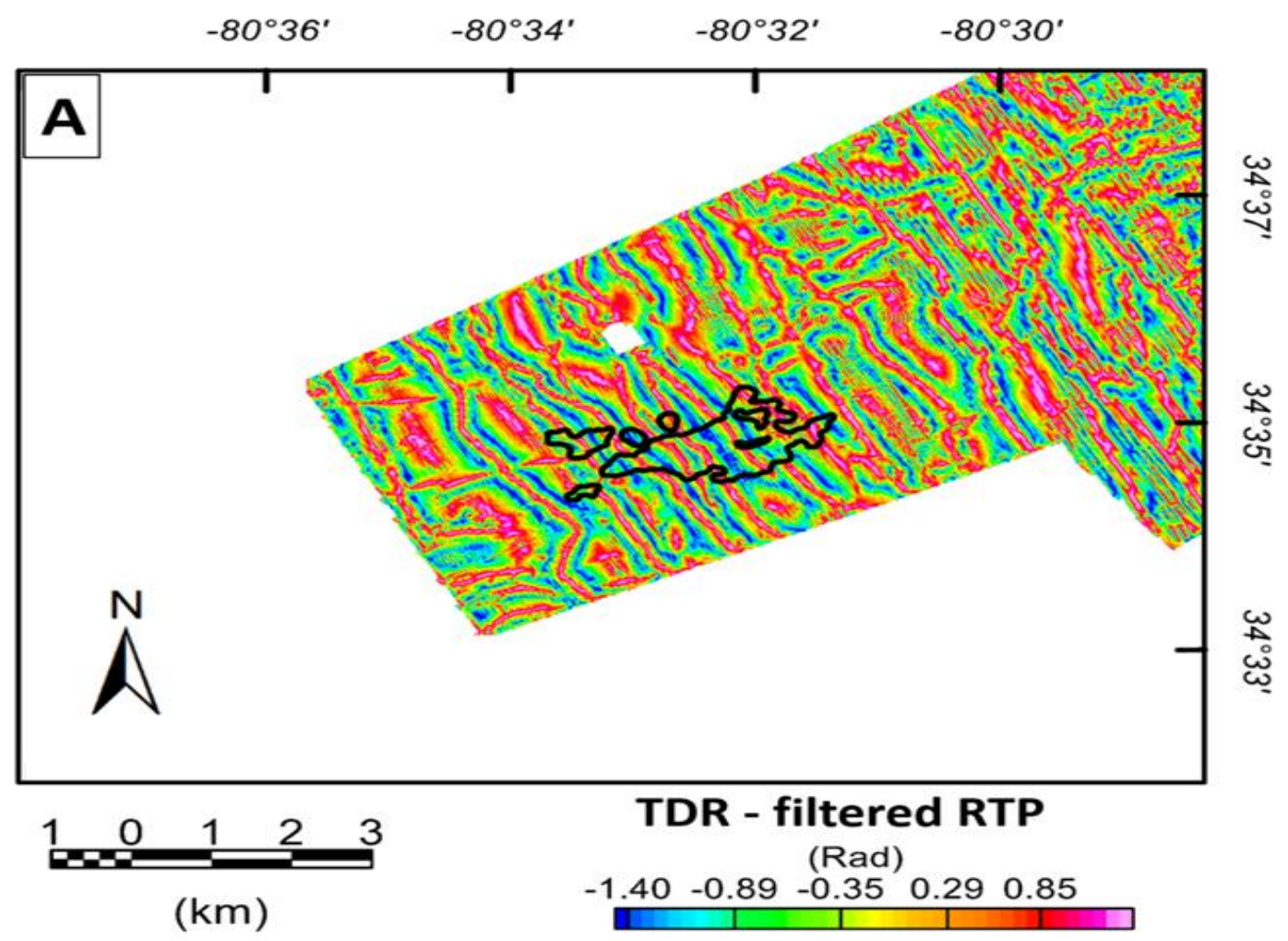

(Rad)
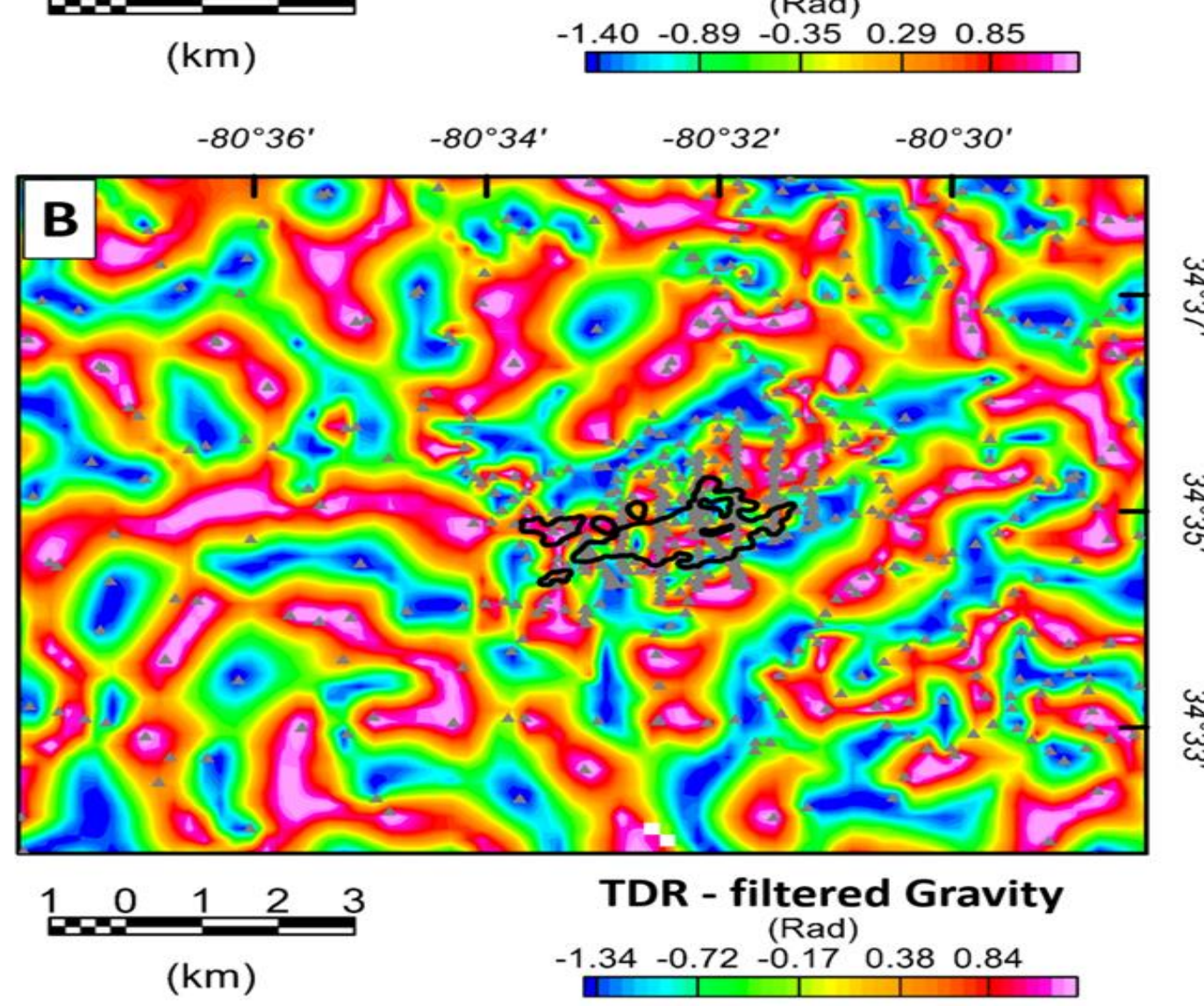

Figure 2.7: A) TDR of filtered RTP magnetic map (Figure 2.5b). B) TDR of filtered Bouguer anomaly map (Figure 2.5d). Black outline is Haile Mine ore body extent. 

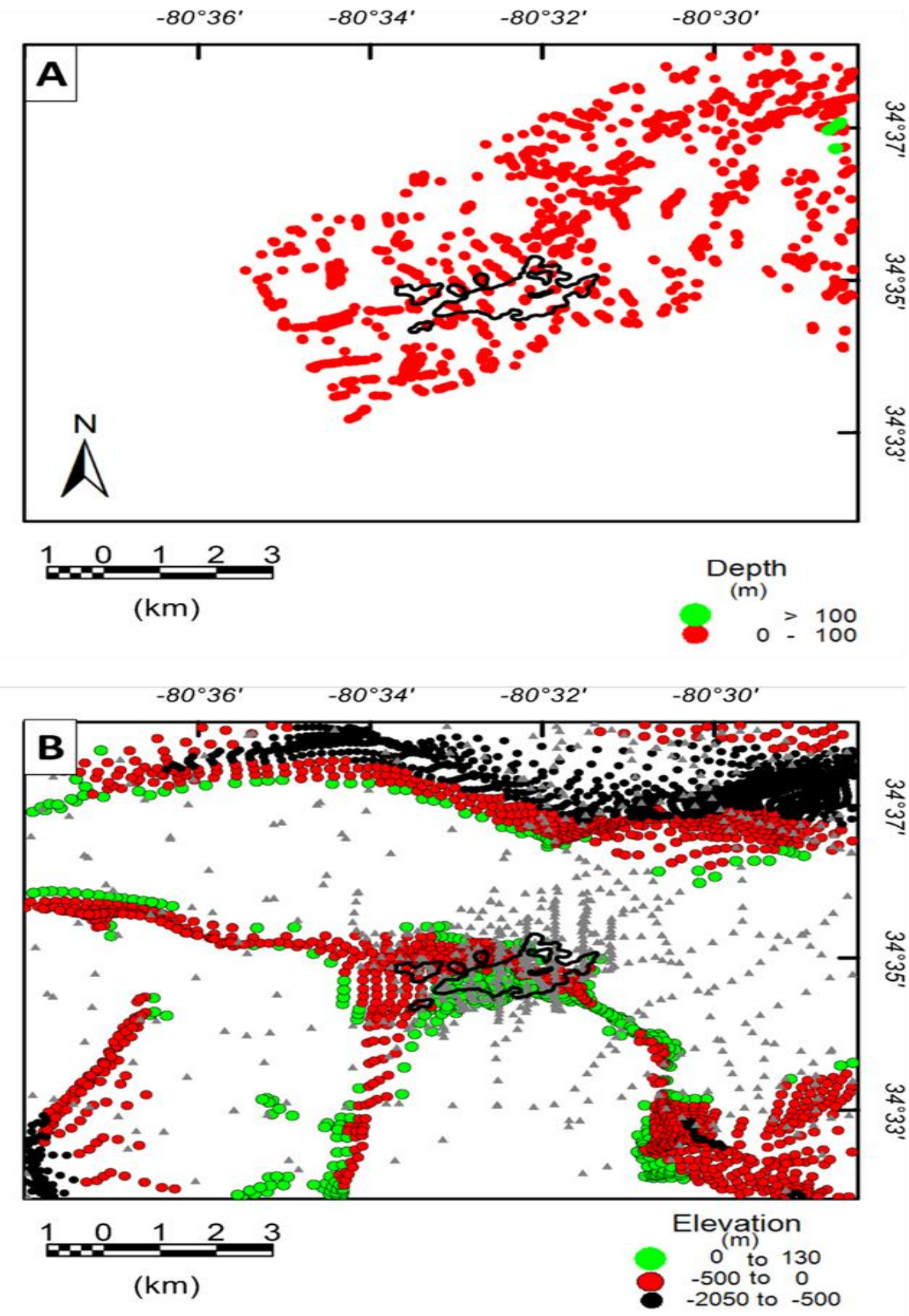

Figure 2.8: A) ED of the TMI magnetic map. Structural Index: 0 (contacts). Depth calculated relative to ground surface. B) ED of Bouguer anomaly map. Elevation above sea level. Structural index: 0 (sill, dike, fault) 


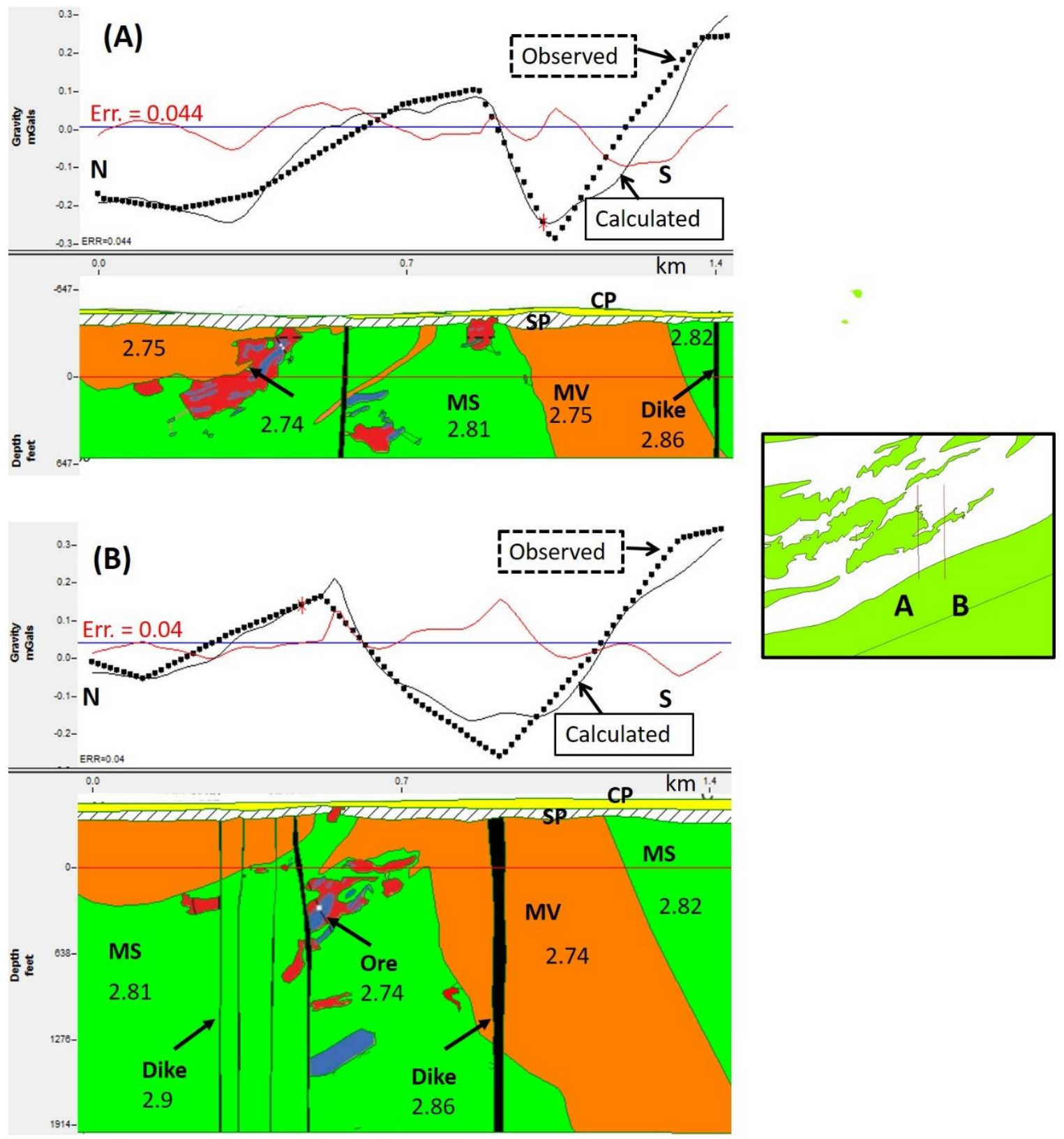

Figure 2.9: 2-D forward density modeling. Top is profile A. Bottom is profile B. In the middle is a geological map showing metasedimentary units (green) and the two profile locations. Gravity station spacing is approximately $100 \mathrm{~m}$. Note that the gravity values are filtered residual anomalies, and the total amplitude of the modelled anomalies is only 0.5 mGal! Geology after Mobley et al. (2014) and SRK Consulting (2017). Polygon densities are from Table 2.3. Density of saprolite: $2.45 \mathrm{~g} / \mathrm{cc}$, Coastal Plain sediments: 2.6 g/cc (James Berry, personal communication, Romarco). Red areas: ore, blue areas: molybdenite, MS: metasedimentary unit, MV: metavolcanic units, SP: saprolite, CP: coastal plain sediments. For geology map see Figure 2.2. $0 \mathrm{~m}$ depth is sea level. No vertical exaggeration: scale is $1: 1$. (For interpretation of the references to color in this Figure legend, the reader is referred to the web version of this article). 

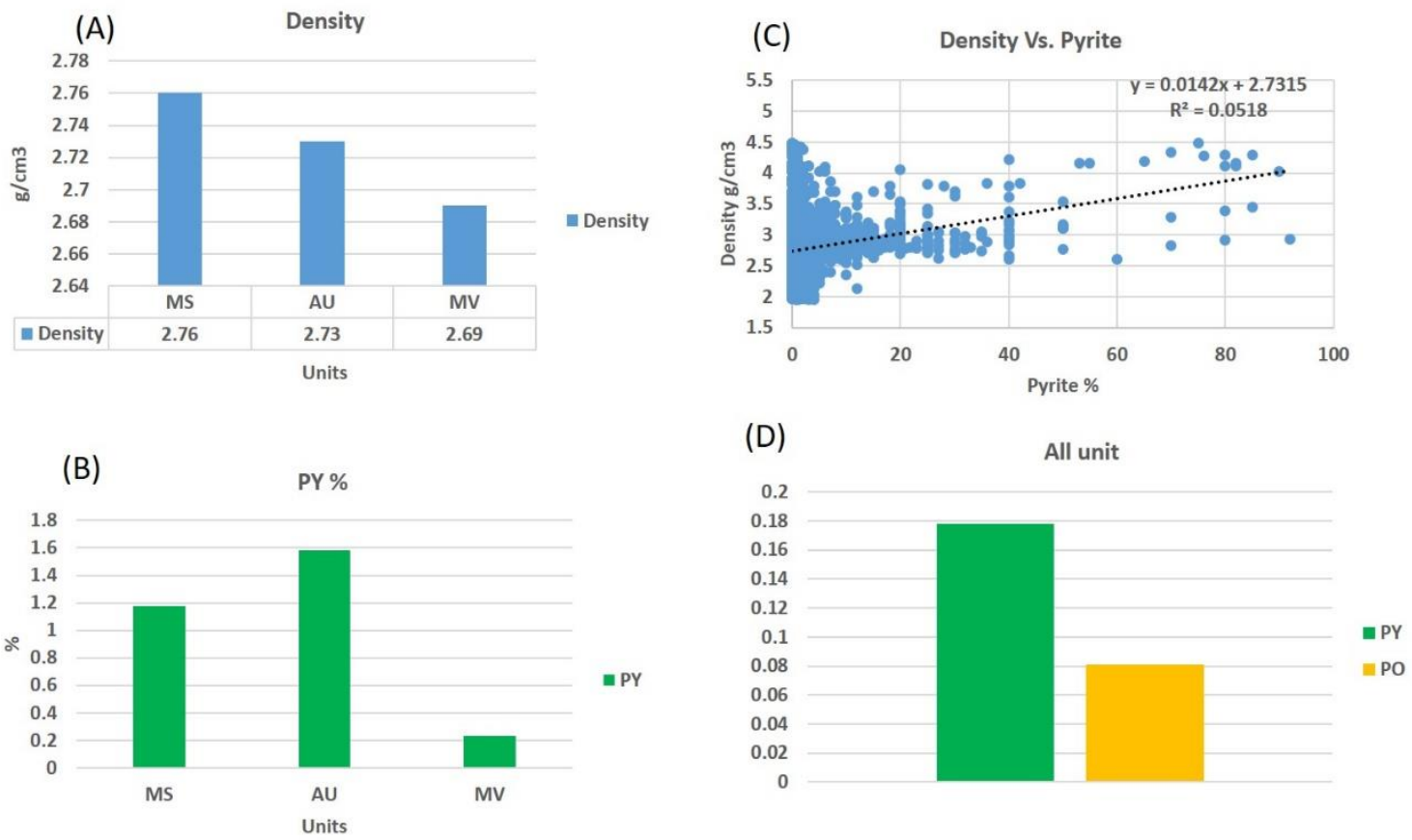

Figure 2.10: A) Average densities of metasedimentary units (MS), gold bearing metasedimentary units (AU) and metavolcanic units (MV) from 49,183 measurements from 448 drill holes (OceanaGold). Number of measurements: MS: 36,061, AU: 31, MV: 13,091. B) Average percentages of pyrite (green) in MS, AU, and MV. C) Sample density vs pyrite \%. D) Correlation coefficient results for minerals and density: pyrite (PY), pyrrhotite (PO). 
(A)

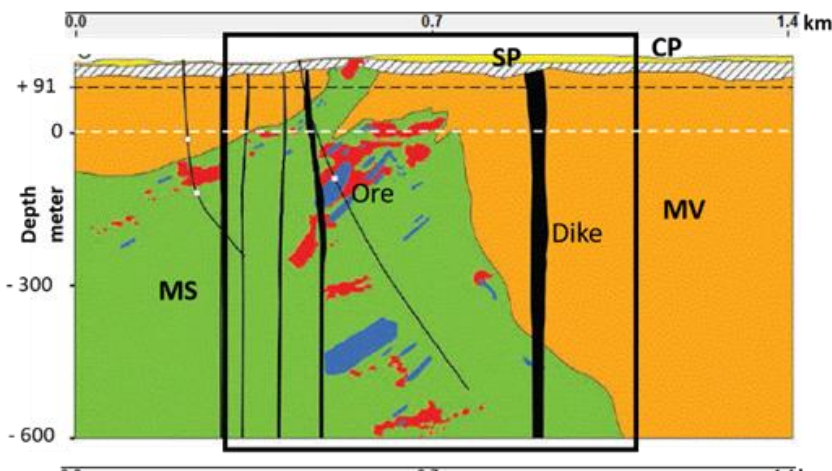

(B)

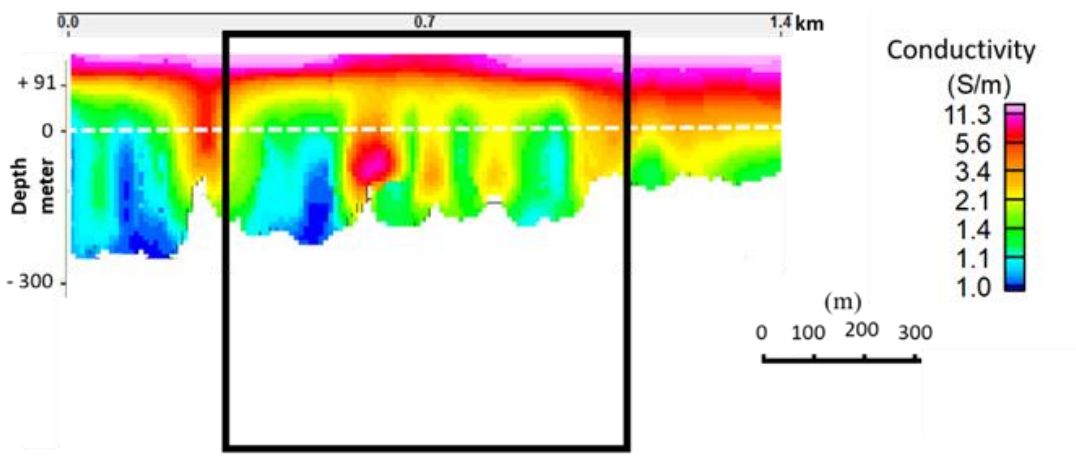

(C)

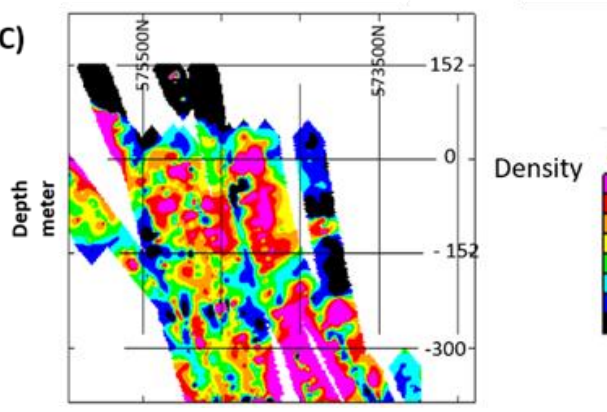

(D)

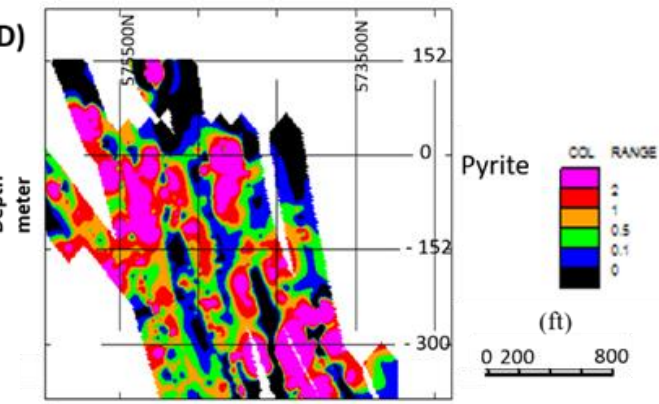

Figure 2.11: A) geological profile B (location: Figures 2.2b and 2.11) after Mobley et al. (2014). No vertical exaggeration and same scale in all profiles. B) Conductivity inverted for depth along profile B. C) OceanaGold measured core densities from wells along profile B. D) OceanaGold lab estimated pyrite concentrations from drill cores along profile B. Small black box in A and B: boundary of Figures 2.13C and 2.13D. Dashed

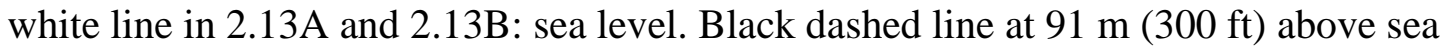
level in 2.13A is the depth of the bedrock map in Figure 2.2. 


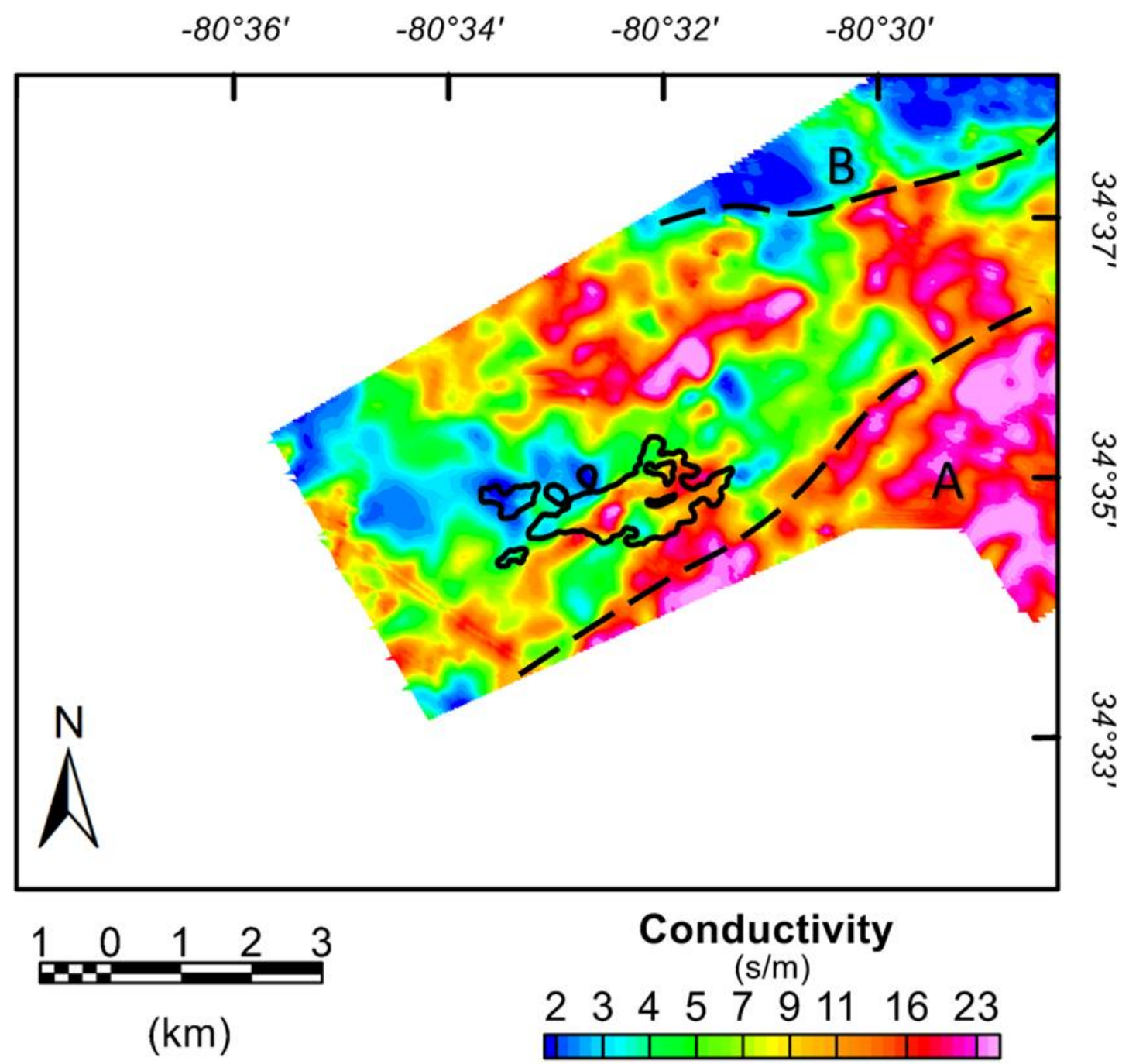

Figure 2.12: Conductivity map from EM survey. The black polygons in the center are the ore zones from the geological map (Figure 2.2b). A: Sub cropping Richtex Formation metasedimentary units (Figure 2.2b). B: Pageland granite intrusion. 


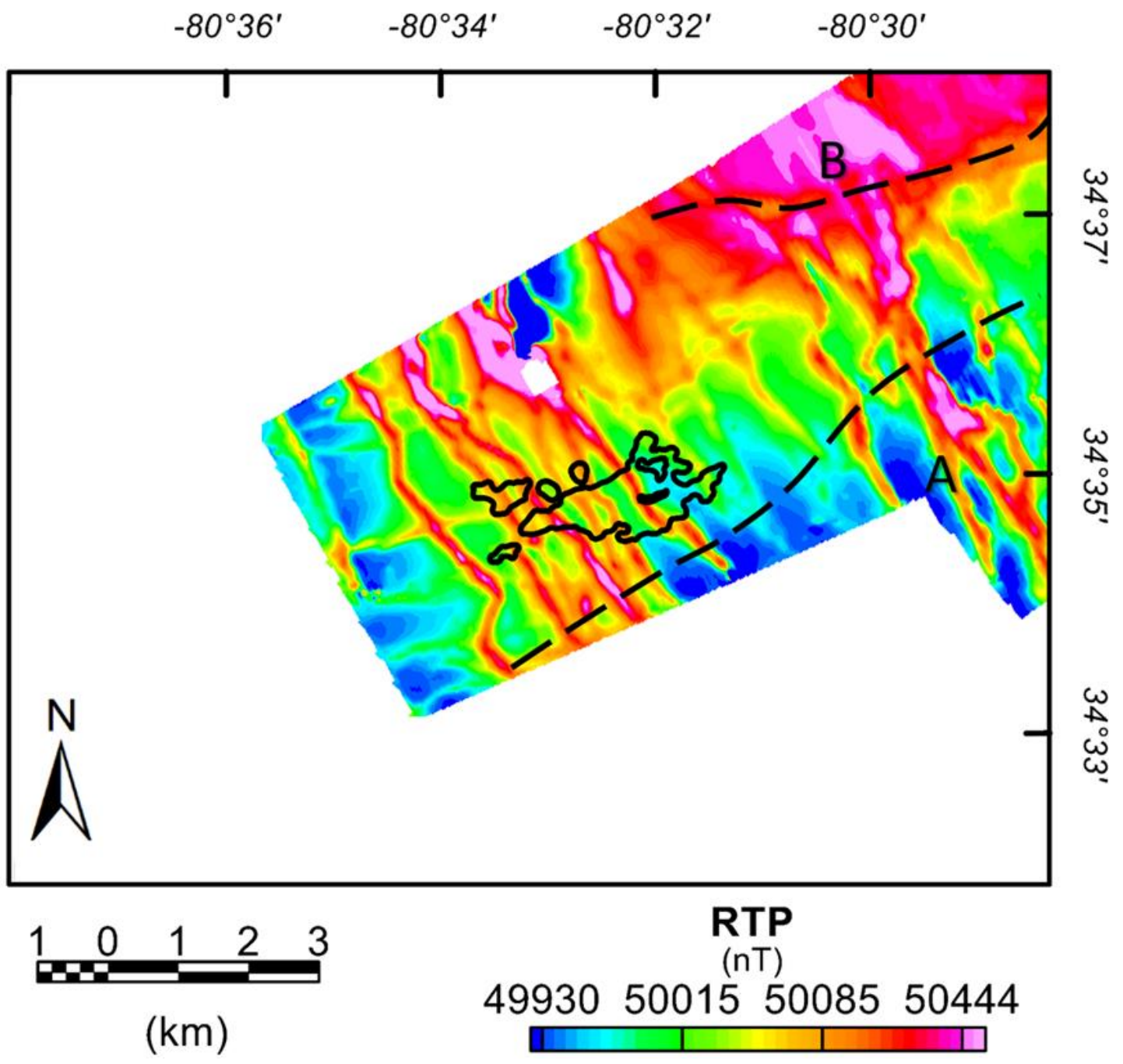

Figure 2.13: RTP magnetic map. A: sub cropping extent of the Ritchtex Formation metasedimentary units (Figure 2.2b). B: Pageland granite intrusion. 


\section{CHAPTER 3}

\section{GEOPHYSICAL STUDY OF GOLD MINERALIZED ZONES IN THE CAROLINA TERRANE OF SOUTH CAROLINA ${ }^{2}$}

Large pyrite-dominated gold deposits are hosted in hydrothermal altered metamorphic rocks in the Carolina slate belt of South Carolina and are partly covered by Coastal Plain sediments. This study investigates the utility of geophysical data, aeromagnetic, electromagnetic, and land gravity as exploration tools. Observed geophysical fields are correlated with rock properties: resistivities, susceptibilities and mineral concentrations measured for 40 samples from 16 new drill holes, as well as densities and pyrite concentrations for 49,183 samples from 448 drill holes in the Haile ore zone. Regional positive gravity anomalies are observed over the Haile, Ridgeway, and Barite Hill mine areas, and residual high pass filtered positive gravity anomalies are observed over all mine areas. New densities and pyrite and sericite percentages for wells in the Haile mine area show that densities and pyrite concentrations are significantly higher in the ore zone. High conductivity electromagnetic anomalies are observed over the Haile and Brewer ore zones as well as over metasediments. Resistivity and mineral correlations for new samples from drill holes in the Haile Mine area suggest that pyrite and porosity in seriticized rocks my increase sample conductivity. Density and conductivity contrasts between metasediments and metavolcanics may permit mapping of

\footnotetext{
${ }^{2}$ Alarifi, S., Kellogg, J., Elkhedr, I., 2019. Geophysical study of gold mineralized zones in the Carolina terrane of South Carolina. Submitted to Economic Geology, 12/13/2019.
} 
the ore bearing contact zone between the two units. High resolution land gravity and helicopter EM datasets for Haile and Brewer mine areas were used to estimate optimal station spacing for geophysical field exploration surveys. The magnetic fields do not correlate with the mineralized zones, but rather with granite and gabbro plutons and diabase dikes. A prominent ENE linear magnetic anomaly is located over the Modoc shear zone separating low grade metamorphic rocks of the Carolina terrane from higher grade metamorphic rocks of the Kiokee belt. We use the Modoc magnetic lineation to predict the southeastern boundary of the Carolina slate belt where it is covered by Coastal Plain sediments.

\subsection{Introduction}

The largest historic gold deposits in the southeastern United States are in the Haile, Ridgeway, Brewer, and Barite Hill mines of the Carolina slate belt. Located in South Carolina, these large pyrite-dominated gold deposits are hosted in hydrothermally altered metamorphic rocks of the Carolina terrane (Figure 3.1), originally part of a volcanic island arc that formed off the coast of Gondwana (Bell 1982; Secor et al., 1983; Hibbard, 2000; Foley et al 2001; Hibbard et al., 2002). The slate belt extends for more than $500 \mathrm{~km}$ from Virginia to Georgia with a maximum width of $140 \mathrm{~km}$ in central North Carolina, constituting a portion of the Carolina terrane (e.g., Secor et al., 1983; Horton et al., 1989; Dennis and Wright 1997; Hibbard 2000; Hibbard et al., 2002; Ayuso et al., 2005). The slate belt is a complex volcanic sequence containing low-grade meta-igneous and meta-sedimentary rocks of Neoproterozoic to Late Cambrian age (Secor et al., 1983). The region has been metamorphosed, folded, and intruded by plutonic of felsic to mafic composition and minor dikes and sills (Worthington and Kiff, 1970). Worthington and 
Kiff (1970) recognized the deposits at the Brewer, Haile, Ridgeway, and Barite Hill as a disseminated gold-pyrite mineralized system hosted by intensely altered rocks (argillic, propylitic, and silicic). Geologic mapping and gold exploration in the Carolina slate belt, however, have been limited by coastal plain sediment and vegetative cover, very poor exposures of bedrock, metamorphism, deformation, and intense weathering.

For subsurface exploration, the gravity method is often integrated with magnetic and electromagnetic methods during integrated base-metal surveys (Telford et al., 1990). Gravity surveys can play a critical role in the identification of pyrite ore bodies with associated polymetallic massive sulfides, such as in the Iberian pyrite belt of Portugal (Oliveira et al., 1998) or the Las Cruces volcanic massive sulfide deposit in Spain (McIntosh et al., 1999). In New Zealand, the adularia-sericite epithermal gold-silver deposits in Waihi and the rhyolite-hosted Karangahake deposit are associated with positive residual gravity anomalies (Morrell et al., 2011; Harris et al., 2005). Similar positive residual Bouguer anomalies occur over the Vangorda, Faro and Swim Lake deposits in the Yukon (Ford et al., 2007). Electromagnetic methods have also been used successfully in the direct detection of massive and disseminated sulfide mineralization (Dentith and Mudge, 2014). Low resistivity is associated with sulfide minerals, and increased porosity in sericitized rocks, and resistivity highs are associated with silicification and intrusions (Ford et al., 2007).

Numerous regional aeromagnetic and gravity studies have been published for South Carolina (e.g., Daniels, 1974; Hatcher and Zietz, 1980; Daniels et al., 1983; Duff and Kellogg, 2019). Very few geophysical studies, however, have been published for the Carolina slate belt and the gold mine areas. The granite plutons near the Haile and 
Brewer mines have distinctive circular gravity lows and magnetic highs (Bell and Popenoe 1976; Fullagar and Butler 1979; Daniels et al., 1983) and have been modeled as laccoliths narrowing to feeder conduits at depth (Tuten, 2013). A ground magnetic and low frequency electromagnetic survey at the Haile mine site in the late 1970s located Mesozoic age diabase dikes and correlated high resistivity responses with silica content (Bell et al., 1980; Wynn and Luce, 1984). In the late 1980s, induced polarization (IP) and ground magnetic surveys by Piedmont led to the discovery of the Snake ore deposit at Haile mine (Larson and Worthington, 1989). Gillon et al. (1995) correlated regional aeromagnetic and vertical derivative anomalies with structural features at Ridgeway mine.

This study presents results from one of the most complete geophysical and drill hole datasets for a gold mine area in the Carolina terrane of the southeastern US. Alarifi et al. (2019) presented preliminary geophysical results from the Haile gold mine in South Carolina that suggested a correlation between pyrite mineralized zones and positive gravity residual and electromagnetic conductivity anomalies. In this paper we present new well results that confirm high concentrations of pyrite as well as high densities in the ore zones. We also present the first conductivity measurements from Haile that demonstrate high conductivities associated with both the ore zones and the metasediments, and high resistivities associated with the metavolcanics. We note in this paper that the density and conductivity contrasts between the metasediments and the metavolcanics offer the possibility of mapping the ore bearing contact zone between the two units. Taking advantage of the high resolution geophysical data for the Haile and Brewer mine areas available for this study, we estimate the data survey density required 
to locate economic ore zones. In this paper we test correlations we observed in the Haile and Brewer geophysical data in the other important gold ore zones in the Carolina slate belt, the Ridgeway and Barite Hill mine areas.

3.2 Geological setting and gold mineralization

The Peri-Gondwanan Carolina terrane (Figure 3.1) is divided into belts of alternating lower to medium metamorphic grade (greenschist facies) of the Carolina slate belt (CB in Figure 3.2) and higher metamorphic grade (schist, amphibolite facies) of the Charlotte (CH) and Kiokee belts (KB in Figure 3.2) (Feiss 1982; Halik 1983; Dennis and Shervais 1996; Murphy et al., 2006). The Charlotte belt is located northwest of the Carolina slate belt, and the boundary is a ductile shear zone of Neoproterozoic age (Barker et al., 1998; Secor et al., 1986a). The Charlotte belt is dominated by granite and gabbroic plutonic rocks that range in age from Neoproterozoic to late Paleozoic, and that intrude a suite of mainly metaigneous rocks (Dennis and Shervais 1996; Murphy et al., 2006). The slate belt also contains intrusive granites, but most are much shallower and younger than those of the Charlotte belt (Murphy et al., 2006).

The southeastern boundary of the Carolina slate belt is almost completely covered by coastal plain sediments of upper Cretaceous to present age (Bell et al, 1974; Popenoe and Zietz 1977). The southeast bedrock boundary of the slate belt, the Modoc ductile fault (shear zone) has very limited exposures (Figure 3.2). The Modoc shear zone separates the slate belt from Neoproterozoic to Cambrian high grade schists and amphibolites of the Kiokee belt (KB, Figure 3.2) that are only exposed in a small area near the Georgia border (Murphy et al., 2006). The Modoc zone exhibits a ductile fabric with quartz lenses and muscovite schists, amphibolite or greenschist grade minerals with 
local mylonite fabrics, and a strong metamorphic gradient across the zone (Secor, 1987;

Sacks and Dennis, 1987; Allard and Whitney 1994). Secor et al. (1986 a, b) and Allard and Whitney (1994) interpreted the shear zone as an Alleghenian sub-horizontal boundary between infrastructure and superstructure, followed by gentle folding, and finally, steeply dipping shearing. This deformation is associated with extensive magmatism within the Modoc shear zone (Allard and Whitney 1994).

The low-grade metamorphic rocks of the Carolina slate belt comprise a slightly deformed upper-crustal terrane of peri-Gondwanan origin (Pollock, 2007; Hibbard et al., 2008). Steeply dipping foliation, bedding, and cleavage characterize most rocks of the slate belt (Bell 1982). Intrusive rocks are divided into three groups based on field relations and composition. The oldest group, Precambrian to Cambrian age, forms mafic to intermediate conformable sills (Worthington and Kiff, 1970). The second group is made of crosscutting granite plutons of Carboniferous age, dominantly biotite granites (Worthington and Kiff, 1970). The third group consists of Triassic to Jurassic age northwest-trending diabase (dolerite) dikes that vary from a few $\mathrm{cm}$ to $40 \mathrm{~m}$ in thickness (Worthington and Kiff, 1970; and SRK Consulting 2017). Lamprophyre dikes at the Haile mine are Alleghenian in age ( 311 Ma) based on 40Ar/39Ar dating of porphyroblastic and biotite are coeval with the Dutchman Creek Gabbro (Mobley et al. 2014). These dikes are mostly ENE-trending ranging in thickness from $10 \mathrm{~cm}$ to $2 \mathrm{~m}$ (Mobley et al. 2014; SRK Consulting 2017) and were mapped for the first time using high-resolution aeromagnetic survey data by Alarifi et al. (2019).

Numerous models have been proposed to explain the origin of the gold deposits at the Carolina Slate belt. Pardee and Park (1948) considered the ore deposits of the 
Carolina slate belt to be granite-related hydrothermal quartz veins. Worthington and Kiff (1970), Spence et al. (1980), and Kiff and Spence (1987) suggested a volcanogenic (syngenetic, marine exhalative) origin. Tomkinson (1988) and Hayward (1992) proposed that the Haile mineralization (Figure 3.2) had a metamorphic origin and was emplaced along regional shear zones and folds. Speer and Maddry (1993) suggested that the Haile mineralization deposits were hydrothermally emplaced and subsequently recrystallized, deformed, and remobilized during regional metamorphic events. All the gold deposits are hosted in similar geologic settings near the contact between the metamorphosed volcanoclastic (Persimmon Fork Formation) and metamorphosed sedimentary rocks (Richtex Formation) of Neoproterozoic to Early Cambrian age (Worthington and Kiff, 1970; SRK Consulting 2017). Near the ore zones the Richtex unit is intensely faulted, hydrothermally altered, and silicified near its contact with the Persimmon Fork unit (Balinsky, 1994; Foley et al., 2001). Most gold deposits in South Carolina are recognized as epithermal, disseminated gold-pyrite deposits that occurred as intra-arc rifting progressed from subaerial to shallow submarine (Feiss et al., 1993; Ayuso et al., 2005; Mobley et al. 2014).

Ridgeway (Figure 3.2) is geologically similar to Haile in that it is dominantly sediment-hosted with some mineralized volcanic rocks (Gillon et al., 1995; Gillon et al., 1998; Ayuso et al., 2005). Gillon et al. (1998) and Ayuson et al. (2005) described the deposit at Ridgeway as having been formed in an intra-arc basin, at the transition from pyroclastic felsic volcanism of Persimmon Fork Formation to submarine and predominantly mafic volcanism and turbidite sedimentation of Richtex Formation. Gillon et al. (1998) and Ayuson et al. (2005) suggested that Ridgeway gold mineralization was 
synvolcanic, exhalative, controlled by faulting and associated with hydrothermal activity and sedimentation during the opening of the basin. East-northeast trending zones of faulting, dextral folding, and associated mafic dike intrusions in the Ridgeway mine area are related to Alleghenian tectonothermal events (Gillon et al., 1998).

The Brewer mine (Figure 3.2) is unique and is classified as high-sulfidation epithermal-style gold mineralization (Ayuso et al., 2005; and SRK Consulting 2017). Gold-pyrite-chalcopyrite-enargite ores in breccias are associated with subvolcanic quartz porphyry that intruded rhyodacite to rhyolitic flows and tuffs (Scheetz, 1991; Zwaschka and Scheetz, 1995; Ayuso et al., 2005). The mineralized intensely silicified zone is surrounded by an argillic quartz-sericite-pyrite schist alteration zone (Schmidt, 1985; Lu et al., 1993). These two zones may represent the center of a volcanic system - a cinder zone, a diatreme, or a caldera (Nystrom, 1972). Lu et al. (1993) indicated that the center of the hydrothermal alteration zone system presents abundant pyrite. Scheetz (1991) and Ayuso et al. (2005) concluded that the ore formation at Brewer mine was synvolcanic and formed in an acidic, sulfate-rich, epithermal environment.

The Barite Hill ore (Figure 3.2) is an epithermal volcanogenic massive sulfide deposit with gold and base metal barite mineralization (Foley et al., 2001; Ayuso et al., 2005). Rocks containing abundant barite, pyrite, galena, and sphalerite have the highest gold content (Clark et al., 1999; Ayuso et al., 2005). The mineralization is associated with sericitic and quartz-pyrite alteration (Gunter and Padgett, 1988; Clark et al., 1992). Barite is interpreted to represent the transition from a subaqueous massive sulfide system forming barite, massive pyrite, and silica in an epithermal deposit (Clark et al., 1999). 


\subsection{Stratigraphic overview}

The Carolina slate belt was formed during late Neoproterozoic to early Cambrian time, 630 to $520 \mathrm{Ma}$, according to U-Pb dating of zircon and fossil evidence (Hibbard et al. 2002). In South Carolina, the Carolina slate belt consists of a five kilometer thick sequence of metasedimentary rocks of the Emory, Richtex, and Asbill Pond formations (Figure 3.3) overlying a three kilometer thick sequence of metavolcanic rocks, known as the Persimmon Fork Formation (Secor et al., 1983; Butler and Secor, 1991; Hibbard and Samson, 1995; Hibbard et al., 2002). The lower unit, the Persimmon Fork Formation, is predominantly intermediate to felsic pyroclastic rocks that are rhyodacitic to andesitic in composition (Hibbard et al 2002). The Richtex Formation was deposited conformably on the Persimmon Fork metavolcanics and consist of siltstones, mudstones (Secor and Wagener, 1968) and turbiditic wackes with minor mafic rocks (Dennis, 1995). The turbiditic wackes likely represent volcanic derived debris accumulated in an intra arc basin during rifting (Dennis, 1995; Foley et al., 2001). The main minerals within this unit are quartz, pyrite (generally less than 10\%), mica (up to 50\%), pyrrhotite, and chlorite, (Dennis and Wright, 1997; Hibbard et al., 2002; Mobley et al., 2014).

All the gold deposits are hosted in similar geologic settings near the contact between the Persimmon Fork metamorphosed volcanoclastics and Richtex metamorphosed sedimentary rocks (Figure 3.3; Worthington and Kiff, 1970; SKR Consulting, 2017). The Re-Os age of mineralization at the Haile Mine is $548.7 \pm 2 \mathrm{Ma}$, close to the age of the host rocks at Haile and Ridgeway, $553 \pm 2$ and $556 \pm 2 \mathrm{Ma}$, respectively (Mobley et al., 2014). Thus, the mineralization occurred while the Carolina Terrane was still located in a peri-Gondwana location (Mobley et al., 2014). 
The upper and lower units of the Carolina slate belt rocks are cut by Carboniferous granites and numerous northwest-southeast trending Triassic-Jurassic age diabase dikes (Bell 1982). Thin (0.1 to $2 \mathrm{~m}$ thick) lamprophyric alkaline dikes are also observed in the Haile mine area (Mauger, 1988; Maddry and Kilbey, 1995). The lamprophyre dikes contain biotite and plagioclase with chlorite and calcite and are mostly east-northeast trending (SRK Consulting, 2017).

In the area of the ore deposits, unconsolidated and poorly indurated rocks of Upper Cretaceous and younger sediments of the Atlantic Coastal Plain unconformably overlie the crystalline rocks (Bell 1982). Deep weathering and leaching have affected both Coastal Plain sedimentary rocks and the underlying crystalline rocks and the ore deposits (Bell 1982). There are three Upper Cretaceous formations, the Tuscaloosa Formation, composed chiefly of light-colored sand and clay; the Black Creek Formation, consisting in its lower part of dark-gray to black leaf-bearing laminated sand and clay and in its upper part of the sandy marl containing marine fossils; and the Peedee Formation, composed chiefly of gray sand and marl-stone (Cooke 1936).

\subsection{Data sets and methodology}

The regional aeromagnetic and ground gravity data (Figure $3.4 \mathrm{~A}$ and $\mathrm{B}$ ) that are used in this study were obtained from USGS (Daniels, 2005; https://pubs.usgs.gov/of/2005/1022/). The aeromagnetic data had been acquired by the late 1960s with a nominal flight elevation of $152 \mathrm{~m}$ above terrain. The flight line spacing was $1600 \mathrm{~m}$ for most of the study area, and $600 \mathrm{~m}$ over the Haile and Brewer mine areas. In addition, an Aeroquest helicopter survey flown for Romarco in 2011 collected high resolution magnetic and time domain electromagnetic data over the Brewer Mine area 
(Figure 3.7 E and F). The survey was flown with a line spacing of $50 \mathrm{~m}$ over the west block (Haile mine area) and 100 m over the east block (Brewer mine area). The nominal EM bird terrain clearance was $30 \mathrm{~m}$.

High resolution ground gravity data (Figures 3.7 B and 3.8 B) was collected over the Haile and Brewer areas in 2010 by Romarco (now OceanaGold). For this study we merged the high-resolution ground gravity data with the regional gravity data. To correlate gravity anomalies with rock densities, OceanaGold provided 49,183 density measurements from 448 drill holes (Table 3.1). To correlate magnetic and electromagnetic observations with rock properties, 44 resistivity (Table 3.3) and magnetic measurements (Table 3.4) from drill holes in the Haile mine area were made by OceanaGold in 2017 and made available for this study.

Processing methods such as derivatives, directional, or frequency filters aid in the interpretation of potential field data (Hinze et al., 2013; Airo et al., 2014). Structural provinces can be outlined by their characteristic magnetic patterns or trends, or homogeneously irregular magnetic patterns. A directional filter can be used to emphasize a particular structural trend or direction within a structural province (Hinze et al., 2013; Airo et al., 2014; Zahra and Oweis 2016).

The interpretation of the Carolina slate belt presented in this study included filtering the gravity and magnetic grids where the gravity and magnetic wavelength responses can be obtained by taking the Fourier transform of the filtering function (Fuller .1967; Spector and Grant, 1970; Bhattacharya, 1965; Hinze et al., 2013). High pass filtering of the regional gravity data isolated wavelengths less than $19 \mathrm{~km}$ and wavelengths less than $10 \mathrm{~km}$ for magnetic data. 
Depth estimation for the gravity data was performed by 3D Euler deconvolution (Reid et al., 1990). Euler deconvolution is based on Euler's homogeneity equation that relates the potential field (magnetic or gravity) and its gradient components to the location of the source, with the degree of homogeneity $\mathrm{N}$, interpreted as a structural index (Thompson, 1982).

The tilt derivative (TDR) or tilt angle, or local phase, is used to detect the edges of shallow geological sources (Miller and Singh, 1994; Verduzco et al., 2004; Salem et al., 2007, 2008). TDR is a normalized derivative based on the ratio of the vertical (VDR) and horizontal (THDR) derivatives of the field (Salem et al., 2007).

Directional filters (Hinze et al., 2013; Airo et al., 2014) were used to remove the effects of diabase dikes from the magnetic field. The density and susceptibility ranges for common ore minerals and some typical host rocks are shown in Table 3.2 (Airo 2015). 3.5 Results and discussion

The regional gravity and magnetic fields can be used to map the Carolina slate belt, and the Modoc shear zone and Kiokee high grade metamorphic belt hidden to the southeast beneath Coastal Plain sediments. Regional positive gravity anomalies are observed over the Haile, Ridgeway, and Barite Hill mine areas, and residual positive gravity anomalies are observed over all four major mine areas. Aeromagnetic maps highlight igneous intrusions and structural features. Drill core measurements from 49,183 drillhole samples from the Haile mine ore zone indicate the minerals responsible for the high gravity anomalies observed. Electromagnetic (EM) positive conductivity anomalies are observed over both the Haile and Brewer mine areas and possible correlations with mineral concentrations are discussed in this paper. Finally, we took advantage of the high 
resolution data sets we had available for the Haile and Brewer mine areas to recommend optimal station spacing for geophysical economic exploration campaigns in the slate belt. 3.5.1 Regional gravity and magnetic fields - Carolina slate belt, Modoc shear zone, and Kiokee belt

The Bouguer gravity field of the study area (Figure 3.4a) reveals a broad positive gravity anomaly belt that generally coincides with the Carolina slate belt (CB, Figure 3.2) and includes the four major South Carolina gold mine locations. Table 3.1 shows density measurements by OceanaGold for 49183 drill core samples from the Haile mine. The average density of the metasedimentary rocks (Richtex Fm) was $2.76 \pm 0.18 \mathrm{~g} / \mathrm{cm} 3$, and the average density of the metavolcanics (Persimmon Fork Fm) was $2.69 \pm 0.20 \mathrm{~g} / \mathrm{cm} 3$. We believe that the high densities of the low-grade metamorphic rocks, mafic rocks (gabbro intrusives and diabase dikes), and gold ore zone rocks in the Carolina slate belt account for the high regional gravity anomalies observed. Distinctive circular negative gravity anomalies are observed over low density granite intrusives, mostly within the Carolina terrane.

The total magnetic intensity (TMI) aeromagnetic field in Figure 3.4b exhibits generally low magnetic anomalies over the Carolina terrane and gold mine locations and highlights igneous intrusions and structural features. Gabbro plutons can be identified where high gravity anomalies coincide with high magnetic anomalies, north of the Barite Hill mine area for example. Based on their magnetic signature, these plutons were interpreted to have been emplaced after the last regional metamorphic event (Popenoe and Zietz, 1977). Granite laccoliths can be identified where low circular gravity anomalies coincide with high magnetic anomalies near all four mine areas. Northwest- 
southeast trending magnetic anomalies mark diabase dikes, especially near the Haile and Brewer mines.

A total magnetic intensity (TMI) map with a 140 degree directional filter (Figure 3.4c) was calculated to mask the signal from NW-SE trending diabase dikes and improve visualization of other structural trends. A prominent ENE linear magnetic anomaly is located over the mapped Modoc shear zone mylonites where they are exposed southeast of the Barite Hill mine (Figures. 3.2 and 3.4c). The Modoc shear zone separates low grade metamorphic rocks of the Carolina terrane from amphibolite grade metamorphic rocks of the Kiokee belt to the southeast (Dennis, 2016). The Modoc magnetic lineation can be traced to the northeast (Figures. 3.2 and 3.4c) under Coastal Plain sediments into North Carolina where it eventually coincides with the exposed boundary of the Carolina slate belt and high grade metamorphic rocks of the Raleigh/Goochland belt (Figure 1 in Hopson and Hatcher, 1988; Shah et al., 2017). Based on the magnetic lineations in Figure $3.4 \mathrm{c}$ we can map the southeastern boundary of the Kiokee high grade metamorphic belt hidden under the Coastal Plain. It is possible that the belt extends even further to the southeast. Our predicted Kiokee/Raleigh/Goochland belt is also generally characterized by low gravity anomalies (Figure 3.4a). Shah et al. (2017) used airborne radiometric data to map radiometric equivalent thorium (eTh) anomalies over the southeastern US. Shah et al. (2017) noted that high eTh anomalies were observed over high-grade metamorphic terranes, including the Kiokee and Raleigh/Goochland belts where exposed. High eTh anomalies were also observed over the Coastal Plain where we predict that the Kiokee belt is covered (Figure 3.2). Magnetic trends associated with the Modoc shear zone and 
the Kiokee belt can also be seen in the gray color tilt derivative map of the magnetic field in Figure 3.4d.

3.5.2 Regional gravity and magnetic fields - northeastern and southwestern gold mine areas in South Carolina

Figure 3.5 shows the geology, gravity and magnetic fields for the northeastern study area (located in Figures 3.2 and 3.4), including the Brewer, Haile, and Ridgeway mine areas. Figure 3.6 shows the geology, gravity, and magnetic fields for the southwestern study area (see Figures 3.2 and 3.4), including the Barite Hill mine area. The Bouguer gravity anomalies in both study areas range from about $-3 \mathrm{mGal}$ to $12 \mathrm{mGal}$ (Figures 3.5b and 3.6b). Low gravity anomalies (Figures 3.5 and 3.6) are observed over Carboniferous granitic intrusives (Figures $3.5 \mathrm{~b}$ and $\mathrm{c}$ and $3.6 \mathrm{~b}$ and $\mathrm{c}$ ), because of the lower granite density (2.63 g/cc, Tuten, 2013; Duff et al., 2014) relative to the surrounding metamorphic country rock (Table 3.1: metasediments $2.76 \pm 0.18 \mathrm{~g} / \mathrm{cc}$, metavolcanics $2.69 \pm 0.20 \mathrm{~g} / \mathrm{cc}$ ). High gravity anomalies are observed over gabbro intrusives, diabase dikes, and the metasediments and metavolcanics in the Carolina terrane (Figures 3.5 and 3.6). High pass filtered gravity maps are shown in Figure 3.5c for the northeast area (wavelength cutoff $=3 \mathrm{~km}$ ) and in Figure 3.6c for the southwest area (wavelength cutoff $=15 \mathrm{~km}$ ). Regional positive gravity anomalies are observed over the Haile, Ridgeway, and Barite Hill mine areas, and residual positive gravity anomalies are observed over all four mine areas. We will present evidence in the following sections that the high gravity anomalies are linked to high concentrations of pyrite in the metasediments and mineralized zones. 
Total magnetic intensity (TMI) maps are shown for the northeast (Figure 3.5d) and southwest study areas (Figure 3.6d). High pass magnetic maps for the northeast (Figure 3.5e) and southwest (Figure 3.6e) were filtered with a cutoff wavelength of 10 $\mathrm{km}$. The magnetic fields do not show correlations with the mineralized zones, but are instead dominated by granitic and gabbro plutons (Figures 3.5d, 3.5e, 3.6d, and 3.6e) and northwest trending diabase dikes (Figure 3.5d). Magnetic susceptibilities in granites range widely from $1 \times 10^{-5}$ [cgs] in leucocratic granites up to $1.3 \times 10^{-3}$ [cgs] in some granodiorites and tonalites and $200 \times 10^{-5}$ [cgs] in some gabbros (e.g., Rochette et al., 1992; Tarling and Hrouda, 1993; Gleizes et al., 1993; Magalhães et al., 1994; Borradaile and Henry, 1997; Bouchez, 1997; Lillie, 1999; Gregorová et al., 2003; Aydin et al., 2007). In North Carolina, the natural remnant magnetization of the Pee Dee gabbro averages $6.9 \times 10^{-3}$ [cgs] and the Lilesville granite averages $1.5 \times 10^{-5}$ [cgs] (Barton and Brown 1983). As noted earlier, a prominent ENE linear magnetic anomaly is located over the mapped Modoc shear zone mylonites where they are exposed southeast of the Barite Hill mine (Figures 3.2, 3.4c, 3.6a, 3.6d, and 3.6e). The Modoc shear zone separates low grade metamorphic rocks of the Carolina terrane from higher grade metamorphic rocks of the Kiokee belt (Dennis, 2016). The Modoc magnetic lineation can be traced to the northeast into the Ridgeway, Haile, Brewer study area (Figures 3.2, 3.4c). We were therefore able to map the linear magnetic anomaly in Figures 3.5d and 3.5e as the Modoc shear zone concealed beneath Coastal Plain sediments (Figure 3.5a). The Modoc fault zone southeast of the Ridgeway, Haile, and Brewer mines is also coincident with a steep gradient in the gravity field (Figures $3.5 \mathrm{~b}$ and $3.5 \mathrm{c}$ ). The Modoc shear zone separates 
high density mafic and greenschist rocks of the Carolina slate belt from lower density schists, gneisses, and amphibolites of the Keokee belt.

Figures 3.5f and 3.6f show Euler deconvolution maps for the gravity fields using a structural index of 0 (sill, dike, fault). The solutions define the Modoc shear zone and the edges of Carboniferous granite intrusions. Solution depths vary from 0 to over $500 \mathrm{~m}$ below sea level. The Liberty Hill (large granite in Figure 3.5a) and Pageland granites (north of Brewer mine) have been modeled as laccoliths (Tuten, 2013) with a $20 \mathrm{~km}$ diameter and $8 \times 16 \mathrm{~km}$ outcrop dimension respectively, narrowing to feeder conduits at about $6 \mathrm{~km}$ depth. Based on the gravity field (Figures. 3.6b, 3.6c, and 3.6f), the Barite Hill granite is a much larger intrusion below ground (about $20 \mathrm{~km}$ diameter) than at the surface (5 km diameter).

3.5.3 Brewer mine area - gravity, aeromagnetic, and conductivity fields

In the Brewer mine area (Figures 3.2, 3.4, and 3.5a), high resolution gravity, magnetic, and EM survey data were available for this study (Figure 3.7). Near the Brewer mine, coastal plain sediments cover much of the bedrock geology (Figure 3.7a). The high resolution gravity field (Figure 3.7b) shows low anomalies over the Pageland granite intrusion. The high pass filtered gravity field (Figure 3.7c with wavelength cutoff $=2 \mathrm{~km}$ ) reveals a positive gravity residual over the Brewer mine area of $2 \mathrm{mGal}$, a feature observed over all four South Carolina gold mine areas. A positive anomaly is also visible in the analytical signal map of the gravity field (Alarifi, 2017). Euler deconvolution solutions of the gravity field (Figure 3.7d) define a broad shallow oval pattern surrounding the Brewer mine area. 
A positive conductivity (low resistivity) anomaly is observed over the Brewer mine area as well as metasedimentary units in the electromagnetic (EM) survey map (Figure 3.7e). Similar positive conductivity anomalies over the Haile mine area and nearby metasediments will be discussed later as well as possible correlation with high pyrite concentrations in the mineralized zones. The high resistivity/low conductivity region surrounding the mineralized zone is consistent with the possible presence of strong silica altered sulphidization of epithermal origin in metavolcanics around the Brewer mine (SRK Consulting, 2017).

Positive anomalies in the high-resolution aeromagnetic map (Figure 3.7f) are observed over the Pageland granite and northwest-southeast-trending diabase dikes. A zone of low residual magnetic anomalies surrounds the ore zone in the high pass filtered magnetic map (Figure $3.7 \mathrm{~g}$. wavelength cutoff $=0.5 \mathrm{~km}$ ). Alarifi $(2017)$ suggested that this circular feature was produced by a hydrothermal alteration zone or metamorphic halo. Hydrothermal alteration with temperatures greater than $150^{\circ} \mathrm{C}$ may gradually destroy magnetite and consequently reduce the magnetization (Airo and Mertanen, 2008; Dentith and Mudge, 2014). Feiss and Vance (1995) predicted hydrothermal alteration associated with a ring fractured zone around the Brewer ore zone.

3.5.4 Haile mine area - gravity, magnetic, and electromagnetic results

High resolution gravity, aeromagnetic, and conductivity data for the Haile mine area are shown in Figure 3.8. Alarifi et al. (2019) noted that positive residual gravity anomalies from spectral analysis (Figure 3.11e), as well as first vertical derivatives and tilt derivatives of gravity correlated with the mineralized ore zone. Euler deconvolution of the gravity field also showed numerous shallow sources in the ore zone (Alarifi et al., 
2019). Drill core measurements from 49,183 drill hole samples (Table 3.1) show that metasediments (Richtex Formation), $(2.76 \mathrm{~g} / \mathrm{cm} 3)$ and gold bearing samples $(2.73 \mathrm{~g} / \mathrm{cm} 3)$ are slightly denser than metavolcanics (Persimmon Fork Formation) $(2.69 \mathrm{~g} / \mathrm{cm} 3)$. Correlation coefficients indicated that pyrite was the main mineral increasing sample density (Alarifi et al., 2019). Figure 3.9 shows average rocks densities and pyrite percent for 5 wells in the Haile ore zone, 4 wells east of the ore zone, and 3 wells south of the ore zone. The well results show that average rock densities and pyrite percentages are significantly higher in the ore zone.

Similar to the Brewer mine area, high conductivity anomalies are observed over the Haile ore zone as well as over the metasediments (Figure 3.8d). Core drilling and 2D inversion showed that high conductivity anomalies coincided with zones of high pyrite concentrations (Alarifi et al., 2019). For this study, OceanaGold has released new resistivity and susceptibility measurements, and visually assessed mineral concentrations for 40 samples from 16 drill holes in the Haile Mine area. The average resistivities (Table 3.3) are metasedimentary: $1814 \mathrm{Ohm}-\mathrm{m}$, metavolcanics: $2366 \mathrm{Ohm}-\mathrm{m}$. The correlation coefficient for sample resistivity and pyrite percentage is $(0.08)$. Figure 3.10 shows the average $\%$ concentration of pyrite in metavolcanic and metasedimentary rocks. The higher concentration of pyrite in the metasedimentary units (Figure 3.10) and high concentrations of pyrite in the ore zones (Figure 3.9b) may explain the higher conductivity observed over the metasediments and the mineralized zones (Figure 3.8d). In addition, other sulfide minerals and increased porosity in sericitized rocks may enhance the conductivity of the mineralized zones and the metasediments (Takakura et al., 2012; Airo, 2015). As noted previously, the gold ore mineralization in the Carolina 
slate belt is located near the contact between the metasediments (Richtex Fm) and metavolcanics (Persimmon Fork Fm). The contrasts between the denser conductive metasediments and the lighter resistive metavolcanics offers the exploration opportunity to map the ore bearing contact zone with gravity and electromagnetic methods.

The average magnetic susceptibilities for 40 samples from 16 drill holes in the Haile Mine area (Table 3.4) are metasedimentary: $9.03 \mu \mathrm{cgs}$, metavolcanics: $8.99 \mu \mathrm{cgs}$. Not shown are measurements of magnetic susceptibilities for a diabase dike: $4200 \mu \mathrm{cgs}$, and a lamprophyre dike: $344 \mu \mathrm{cgs}$. The low magnetic susceptibility values for the metasediments and metavolcanics in the Haile ore zone correlate with low mapped TMI values relative to the highly magnetic granites, diabase dikes, and even lamprophyre dikes (Figure 3.8; Alarifi et al., 2019). The mineralized ore zones at Haile and Brewer exhibit no distinctive magnetic anomalies in contrast to the positive residual gravity and conductivity anomalies associated with the ore zones.

3.5.5 Sample spacing and target signal wavelength in the Haile mine area

To help with station spacing planning for geophysical data acquisition field campaigns to detect mineralized zones in the Carolina slate belt, we took advantage of the high-resolution data sets we had available for the Haile mine area. We focused on land gravity data, since positive residual gravity anomalies are observed over the Haile (Figure 3.11e) and Brewer mine areas (Figure 3.7c), and because we had both low resolution regional gravity data (USGS, Figures 3.11a-3.11c) as well as high resolution land gravity (OceanaGold, Figures 3.11d-f). The Haile mine area gravity data consist of approximately 73 regional USGS observations with a mean separation of 1370 meters and an additional 657 OceanaGold observations with a mean separation of 167 meters. In 
the Haile ore zone, however, there are only 9 USGS observation with a mean separation of 1670 meters in contrast with 340 Oceanagold observations with a mean separation of 88 meters. At Haile the ore body extends $3 \mathrm{~km}$ to the ENE and $1 \mathrm{~km}$ to the NNW (Figures 3.8a, 3.11). The target residual gravity anomaly is $1.5 \mathrm{~km}$ x $0.5 \mathrm{~km}$ (Figures $3.11 \mathrm{e}$ ), the Euler target is $3 \mathrm{~km} \times 1 \mathrm{~km}$ (Figure $3.11 \mathrm{f}$ ), and the conductivity anomaly is 2 $\mathrm{km} \times 0.5 \mathrm{~km}$ (Figure 3.8d). At Brewer the residual gravity anomaly is a much clearer 3 $\mathrm{km} \times 2 \mathrm{~km}$ feature (Figure 3.7c), and the conductivity anomaly is $1 \mathrm{~km}$ in diameter (Figure 3.7e). The regional gravity survey spacing at Haile resolves neither a positive residual anomaly (Figure 3.11b) nor a cluster of Euler solutions (Figure 3.11c). The highresolution survey (Figures $11 \mathrm{~d}$, e, and f), however, resolves a small residual gravity anomaly (Figure 3.11e) as well as a cluster of shallow Euler solutions (Figure 3.11f).

Figure 3.12 shows a 2-D forward density model for the north-south Haile mine profile located in Figure 3.11a after Alarifi et al. (2019). The north-south wavelength of the positive residual gravity anomaly is $0.7 \mathrm{~km}$. The observed high-resolution land gravity data was sampled at station spacings of 100, 250, and 400 meters (Figure 3.12a). The 0.4 $\mathrm{mGal}$ residual gravity anomaly is best observed at $100 \mathrm{~m}$ spacing, but also seen in the $250 \mathrm{~m}$ spacing.

Standard sampling theory requires at least two samples per the shortest wavelength of signal in any gridded or profiled data set. The Nyquist wavelength $(\lambda N)$ is the shortest spatial wavelength that can be accurately recovered in field work by sequential observations with spacing $\Delta \mathrm{x}$ :

$$
\lambda N=2 \Delta x
$$


If the shortest wavelength of the target residual gravity anomaly signal is $0.5 \mathrm{~km}$, then a minimum $250 \mathrm{~m}$ station spacing is required. Under-sampling the power spectrum aliases long wavelength signal into the results, and under-sampled data sets are not appropriate for modeling or inversion. High sample densities along survey lines do not add significant costs. Data acquired at smaller station spacings are useful for showing both the longer wavelength variations of deeper mineralization as well as the short wavelength near surface variations (Dentith and Mudge 2014). Designing a gravity survey at an angle of about 30/60 degrees to the strike direction of the geology can often provide more information than one oriented at right angles to the geology (Murray and Tracey 2001). For gravity, magnetic, and, to a certain extent, radioactive and electrical surveys, the apparent areal extent of the geophysical anomaly depends on the distance between the plane of observation and the body being sought as well as on the areal extent of the body itself (Agocs, 1955). The issue to be solved is to find the probability of detecting a geophysical anomaly of the required minimum dimensions with a given survey spacing. This is a problem in continuous geometric probabilities for which the mathematics has been considered by Agocs (1955). For the case of elongate anomalies of length $L$, the probability of crossing such features with line spacing $S(\geq L)$ would be $2 \mathrm{~L} / \pi \mathrm{S}$. In case of body length $\mathrm{L}$ equal to the spacing $\mathrm{S}$, the probability of detecting the body by a survey is 0.636 . While in case the body having a length $\mathrm{L}$, greater than the line spacing S, the probability of seen such features would be

$$
\frac{2 L}{\pi S}\left[1-\sqrt{ }\left(1-S^{2} / L^{2}\right)\right]+\frac{2}{\pi} \cos ^{-1}(S / L)
$$

(Agocs 1955) 
The probability to see a $1 \mathrm{~km}$ x $3 \mathrm{~km}$ ore body anomaly over the Haile mine area with $400 \mathrm{~m}$ station spacing is 0.858 , the probability to see the anomaly with $250 \mathrm{~m}$ spacing is 0.896 . However, the probability to see the anomaly with $100 \mathrm{~m}$ spacing is 0.964 , thereby minimizing the risk of missing the target anomaly.

\subsection{Conclusions}

Regional positive gravity anomalies are observed over the Haile, Ridgeway, and Barite Hill mine areas, and residual positive gravity anomalies are observed over all four major South Carolina mine areas. Euler deconvolution of the high resolution gravity field also showed numerous shallow sources in the Haile ore zone. Drill core measurements from 49,183 drillhole samples show that metasediments (Richtex unit), (2.76 g/cm3) and gold bearing samples $(2.73 \mathrm{~g} / \mathrm{cm} 3)$ are slightly denser than metavolcanics (Persimmon Fork Formation) (2.69 g/cm3). Alarifi et al. (2019) demonstrated a significant correlation between pyrite concentrations and density at the Haile mine. In this paper we present average rocks densities and pyrite percent for 12 wells in the Haile ore zone area that confirm that both rock densities and pyrite percentages are significantly higher in the ore zone.

High conductivity anomalies are also observed over the Haile and Brewer ore zones as well as over the metasediments. New measurements on samples from Haile demonstrate high conductivities associated with the metasediments and high resistivities associated with the metavolcanics. The higher concentration of pyrite in the metasedimentary units and high concentrations of pyrite in the ore zones may explain the higher conductivity observed over the metasediments and the mineralized zones. In addition, other sulfide minerals and increased porosity in sericitized rocks may enhance 
the conductivity of the mineralized zones and the metasediments. Since the gold ore mineralization in the Carolina slate belt is located near the contact between the metasediments and metavolcanics, gravity and electromagnetic data can be useful exploration methods to map the contact between the denser conductive metasediments and the lighter resistive metavolcanics, especially where covered by Coastal Plain sediments.

The magnetic fields do not show correlations with the mineralized zones, but are instead dominated by granitic and gabbro plutons and northwest trending diabase dikes. There is apparently, an absence of ferro and paramagnetic minerals such as magnetite and hematite associated with the mineralization. A prominent ENE linear magnetic anomaly is located over Modoc shear zone mylonites where they are exposed southeast of the Barite Hill mine separating low grade metamorphic rocks of the Carolina terrane from amphibolite grade metamorphic rocks of the Kiokee belt. The Modoc magnetic lineation can be traced to the northeast under Coastal Plain sediments into North Carolina where it eventually coincides with the exposed boundary of the Carolina slate belt and high grade metamorphic rocks of the Raleigh/Goochland belt. Based on the magnetic lineations, we were also able to estimate the southeastern boundary of the Kiokee high grade metamorphic belt hidden under the Coastal Plain.

We were able to take advantage of the high-resolution land gravity and helicopter EM datasets for Haile and Brewer mine areas available for this study to estimate optimal station spacing for geophysical field exploration surveys in the Carolina slate belt. Standard sampling theory requires at least two samples per the shortest wavelength of signal in any gridded or profiled data set. For gravity, magnetic, and, to a certain extent, 
radioactive and electrical surveys, the goal is to find the probability of detecting a geophysical anomaly of the required minimum dimensions with a given survey spacing. Using the continuous geometric probability analysis of Agocs (1955), the probability to see a $1 \mathrm{~km} \times 3 \mathrm{~km}$ ore body such as the Haile ore zone with $400 \mathrm{~m}$ station spacing is 0.858 , while the probability to see the anomaly with $100 \mathrm{~m}$ spacing is 0.964 . With the high densities and electrical conductivity associated with the ore zones, high resolution land gravity and airborne electromagnetic surveys are recommended as initial geophysical exploration methods in the Carolina slate belt to accompany the commonly used induced polarization surveys. 


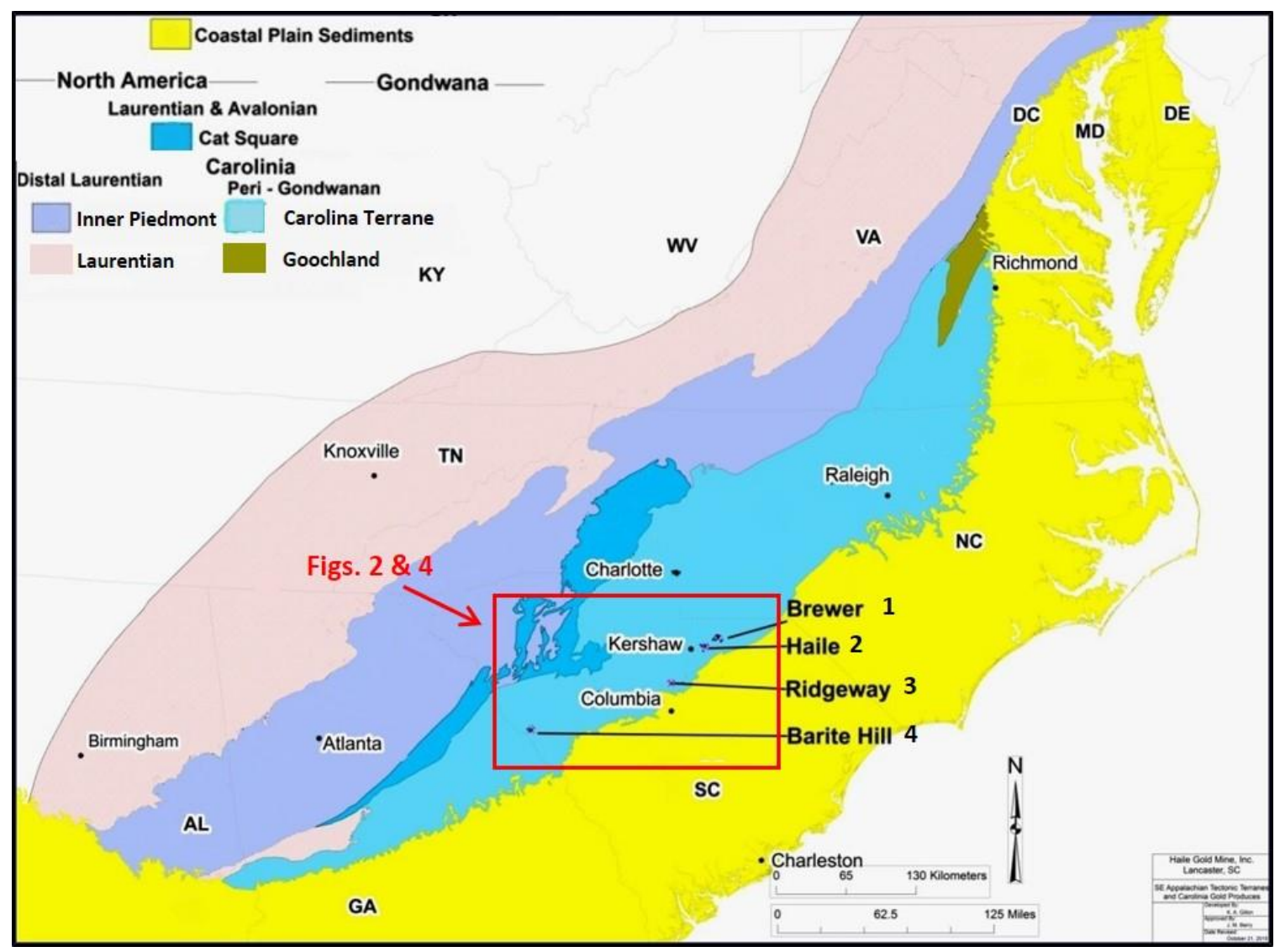

Figure 3.1: Map of the southeastern United States showing major tectonic terranes after unpublished map (K. Gillon and J. Berry, 2013). Four gold mines are shown on this map, Brewer, Haile, Ridgeway, and Barite Hill, all located in lower metamorphic rank volcanic arc rocks of the Carolina terrane. Alabama (AL); Delaware (DE); Georgia (GA); Maryland (MD); North Carolina (NC); Ohio (OH); South Carolina (SC); Tennessee (TN); Virginia (VA); Washington, D.C. (DC), West Virginia (WV). Red rectangle is the study area location (Figures 3.3 and 3.4). 


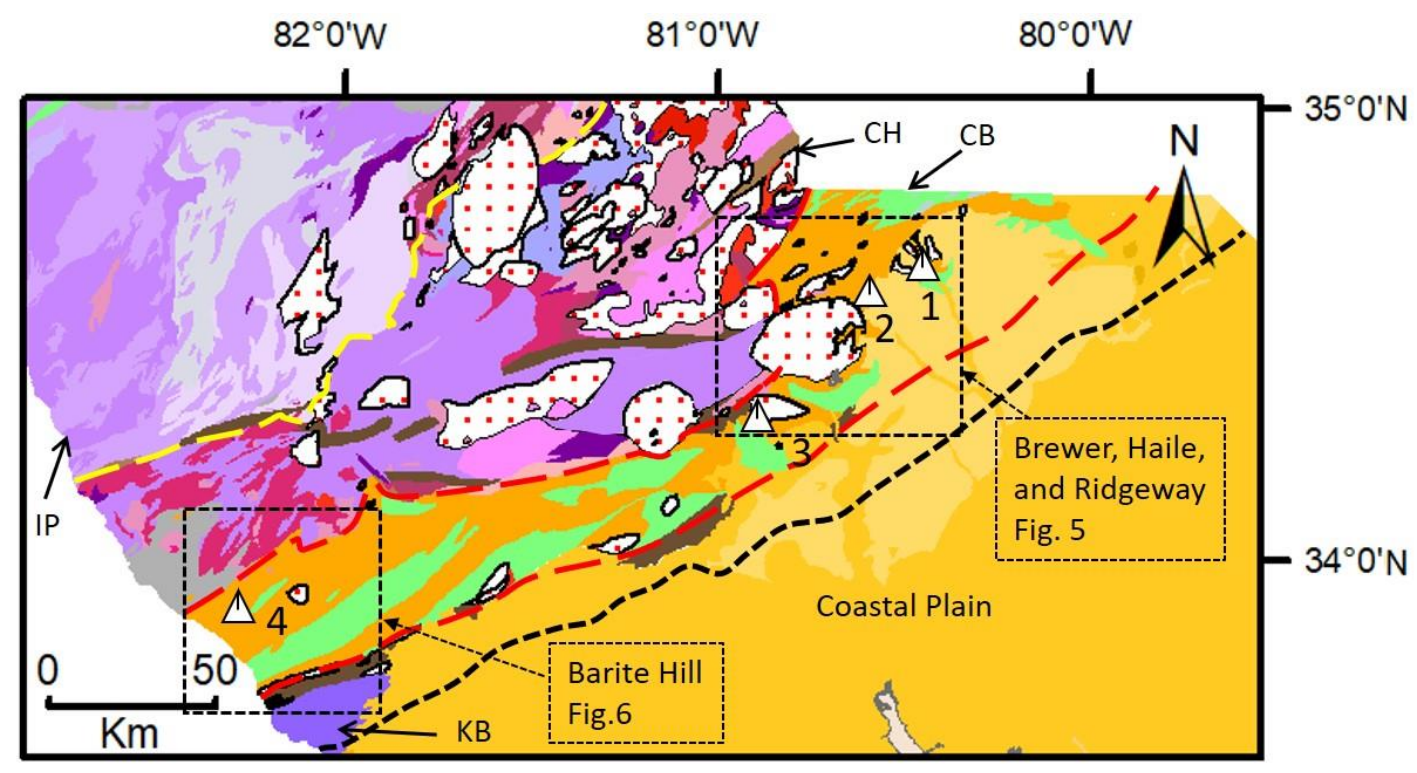

\section{Legend}

\begin{tabular}{|c|c|c|}
\hline Inner Piedmont & Carolina slate belt & Intrusive rocks \\
\hline Gneiss & Persimmon Fork Formation & Granitoid \\
\hline Schist & Richtex Formation & Gabbro \\
\hline Charlotte belt & Modoc zone & Granite \\
\hline Biotite gneiss & Mylonite & Diorite \\
\hline Mica schist & Kiokee belt & \\
\hline Gneiss & Schist & \\
\hline Amphibolite & Coastal plain & \\
\hline Metamorphic rock & Coastal plain sand of Tertiary age & \\
\hline Phyllonite & Coastal plain sand of Pliocene age & \\
\hline
\end{tabular}

Figure 3.2: Geologic map of central South Carolina after Horton and Dicken (2001). Location shown in Figure 3.1. Black rectangles are the study areas. White triangles are gold mine locations same as Figure 3.1: 1) Brewer, 2) Haile, 3) Ridgeway, 4) Barite Hill. Yellow dashed line is the Inner Piedmont (IP) - Charlotte belt $(\mathrm{CH})$ boundary. Red dashed lines are the Carolina terrane $(\mathrm{CB})$ boundaries. Black dashed line is the predicted southeastern boundary of Kiokee high grade metamorphic belt (KB, this paper). 


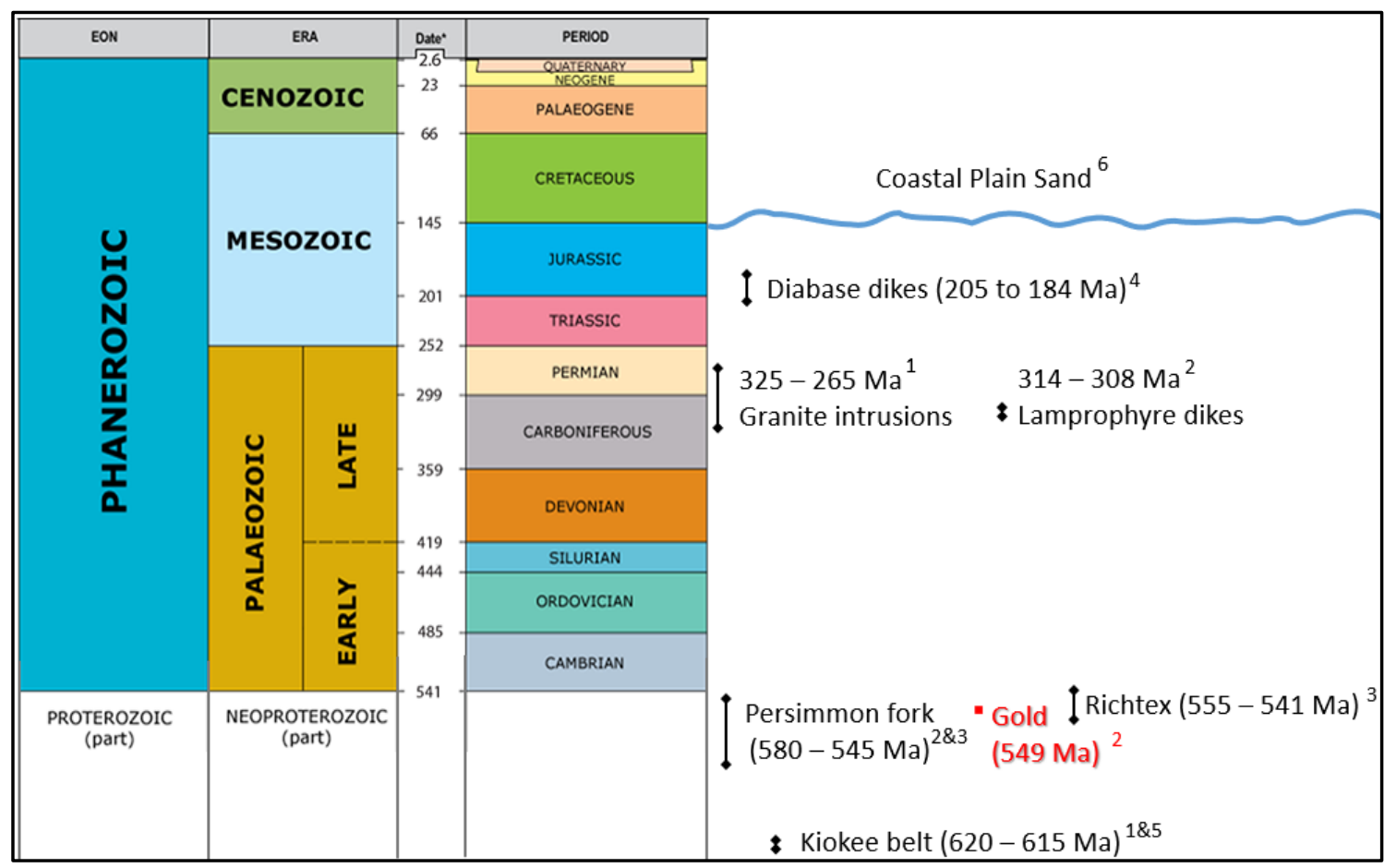

Figure 3.3: Generalized Stratigraphic column. Ages after Hibbard et al. (2002) ${ }^{1}$; Mobley et al. (2014) ${ }^{2}$; Ayuso et al. $(2005)^{3}$; Dooley and Smith (1982) ${ }^{4}$; Dennis et al. (1997) Nystrom et al. $(1991)^{6}$. 


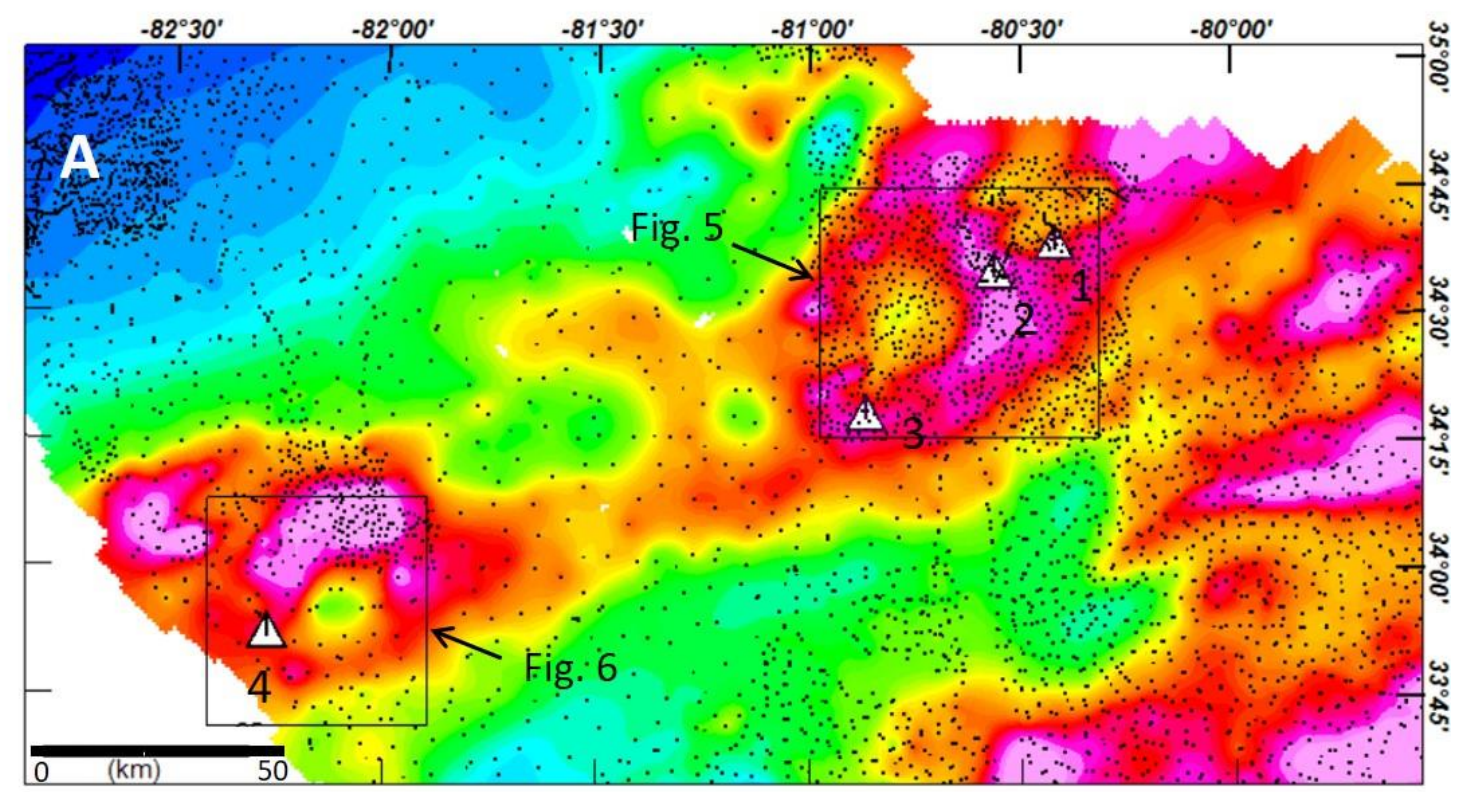

$\begin{array}{llllllllllllllll}-77.5 & -41.9 & -26.0 & -18.2 & -13.6 & -10.1 & -6.9 & -4.7 & -2.9 & -1.5 & 0.1 & 1.8 & 3.6 & 5.5 & 7.7 & 10.9\end{array}$

\section{Bouguer Gravity}

$(\mathrm{mGal})$

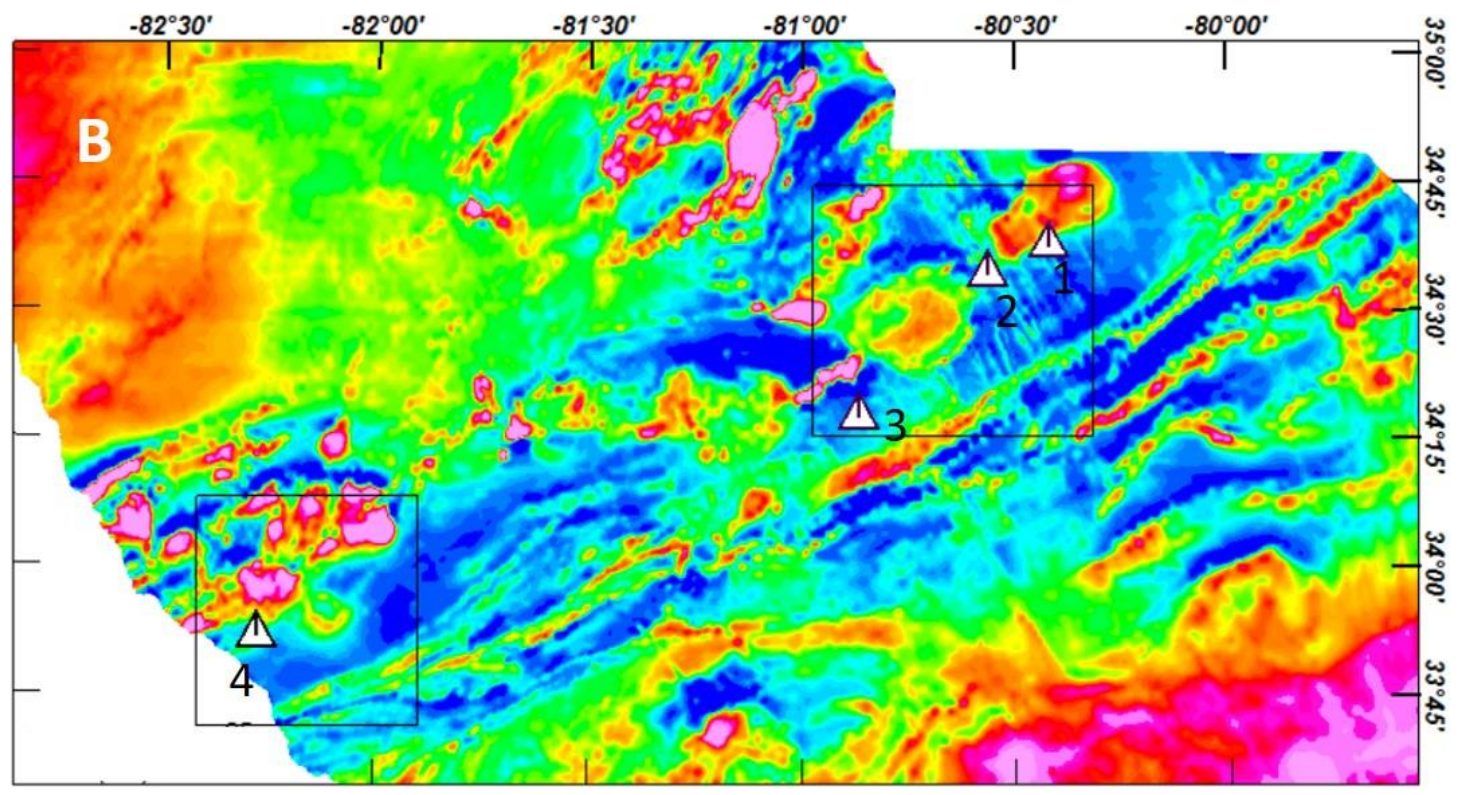

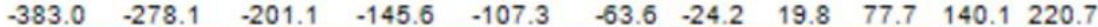

TMI

$(\mathrm{nT})$ 

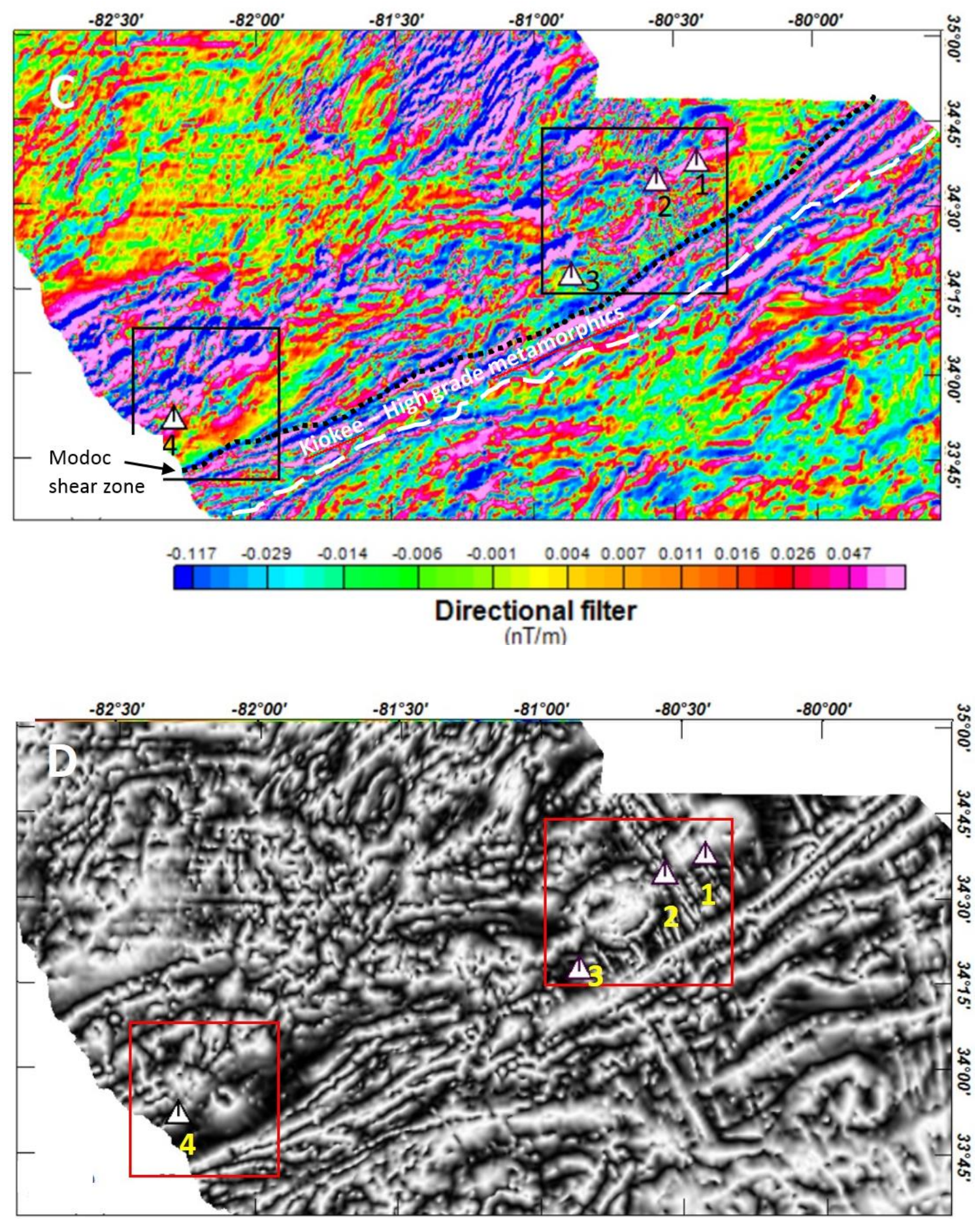

Figure 3.4: A) Bouguer gravity map of South Carolina study area. See Figure 3.1 for location. See Figure 3.2 for geology. Gravity stations shown as black dots. White triangles are gold mine locations same as Figure 3.1: 1) Brewer, 2) Haile, 3) Ridgeway, 4) Barite Hill. B) Total magnetic intensity (TMI) map. C) TMI with $140^{\circ}$ directional filter. Predicted Modoc shear zone and Kiokee high grade metamorphic belt (this paper). D) Tilt derivative of magnetic field in gray color. 


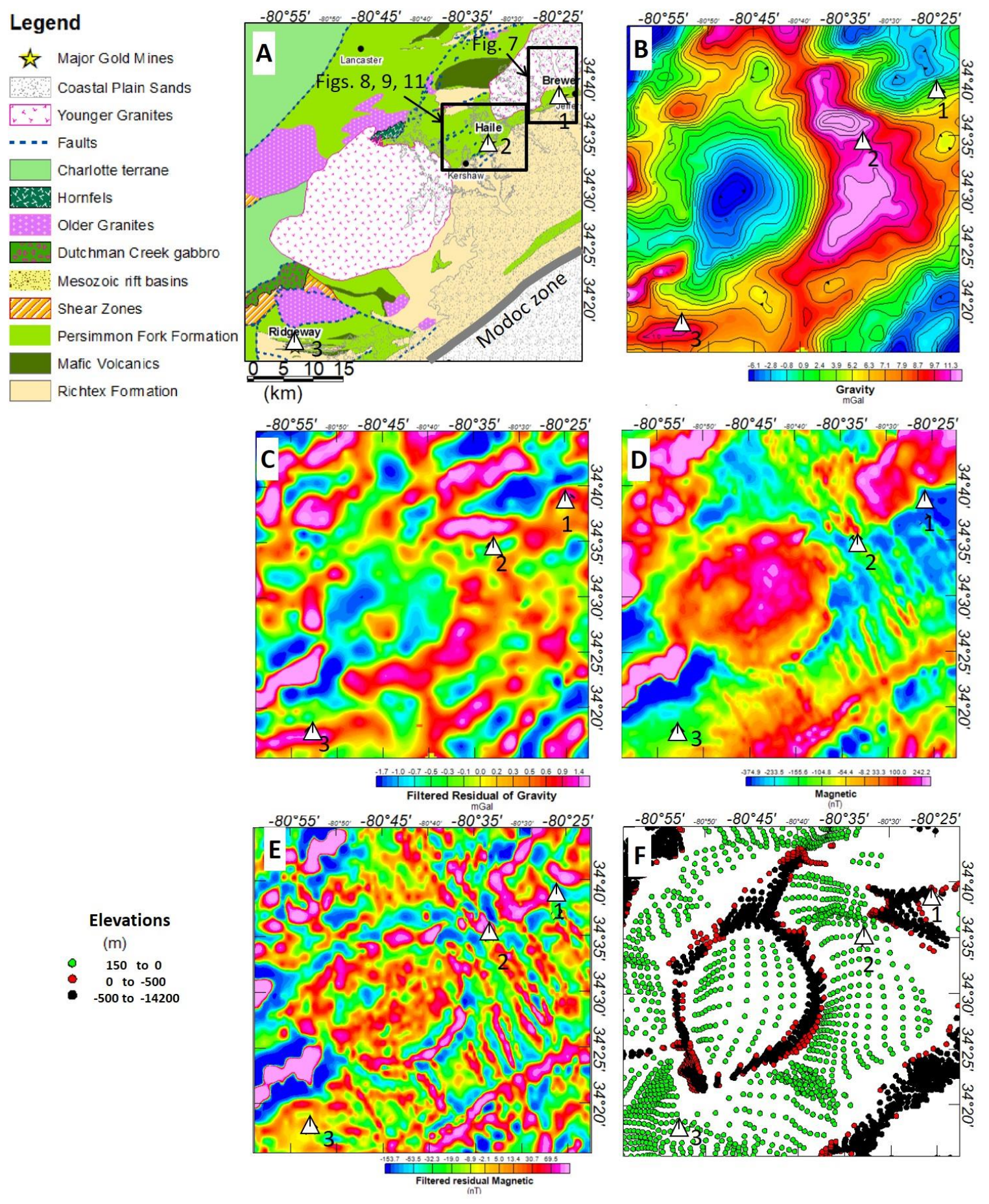

Figure 3.5: A) Geological bed rock map of Brewer, Haile, and Ridgeway mine area after SRK Consulting (2017) showing predicted Modoc shear zone (this paper). For location see Figures 3.2 and 3.4. B) Bouguer gravity anomaly map. C) High pass filter of Bouguer gravity (wavelength cutoff $=3 \mathrm{~km}$ ). D) Total magnetic intensity. E) High pass filter of magnetic $($ TMI) (wavelength cutoff $=10 \mathrm{~km}) \mathrm{F}$ ) Euler solutions for gravity. Elevation above sea level. Structural index is 0 . 

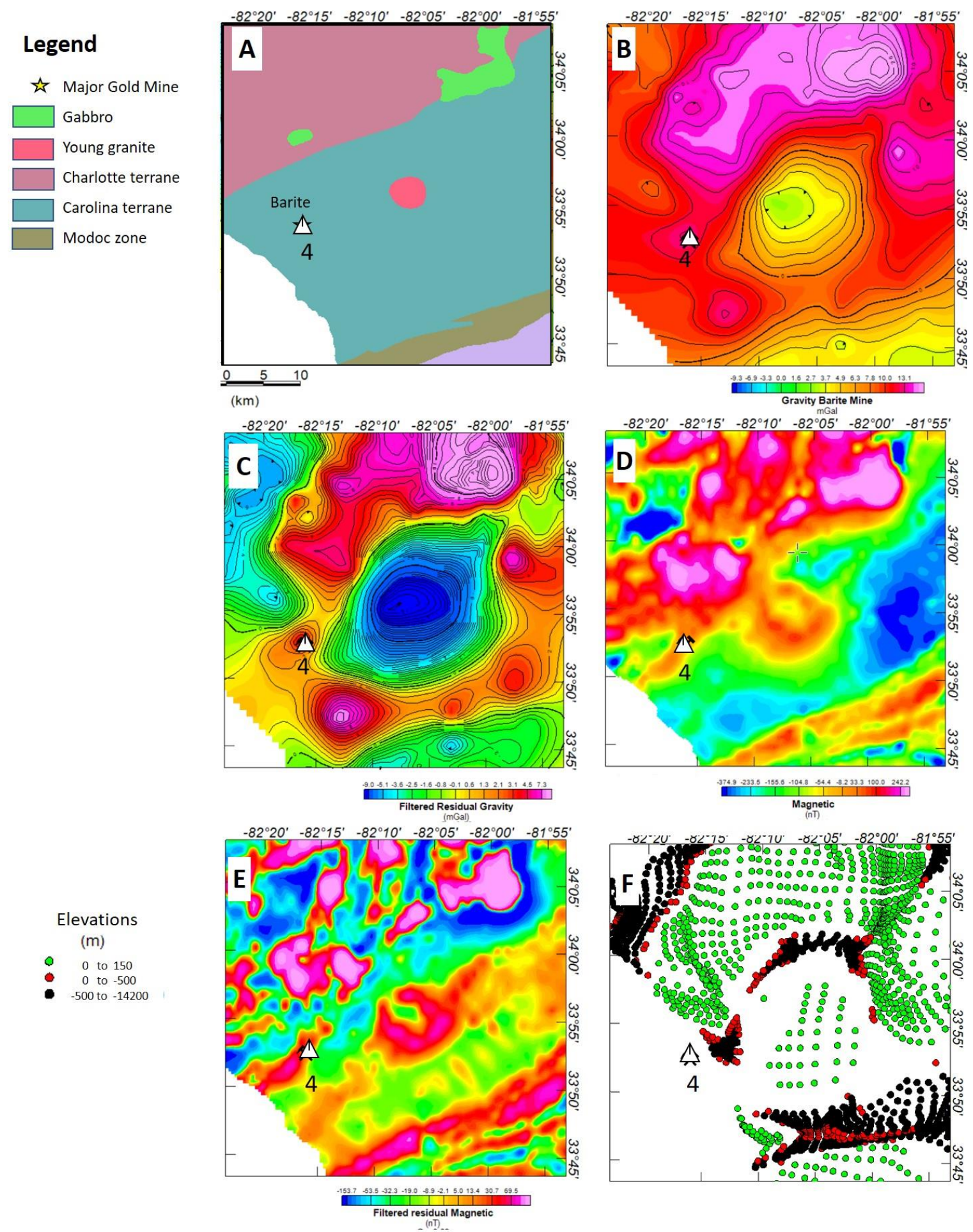

Figure 3.6: A) Geological bed rock map of Barite Hill. See Figures 3.2 and 3.4 for location. B) Bouguer gravity anomaly map. C) High pass filter of gravity (wavelength cutoff $=15 \mathrm{~km}$ ). D) Total magnetic intensity. E) High pass filter of magnetic (TMI) (wavelength cutoff $=10 \mathrm{~km}$ ). F) Euler solutions of gravity. Source elevations above sea level. Structural index is 0 . 

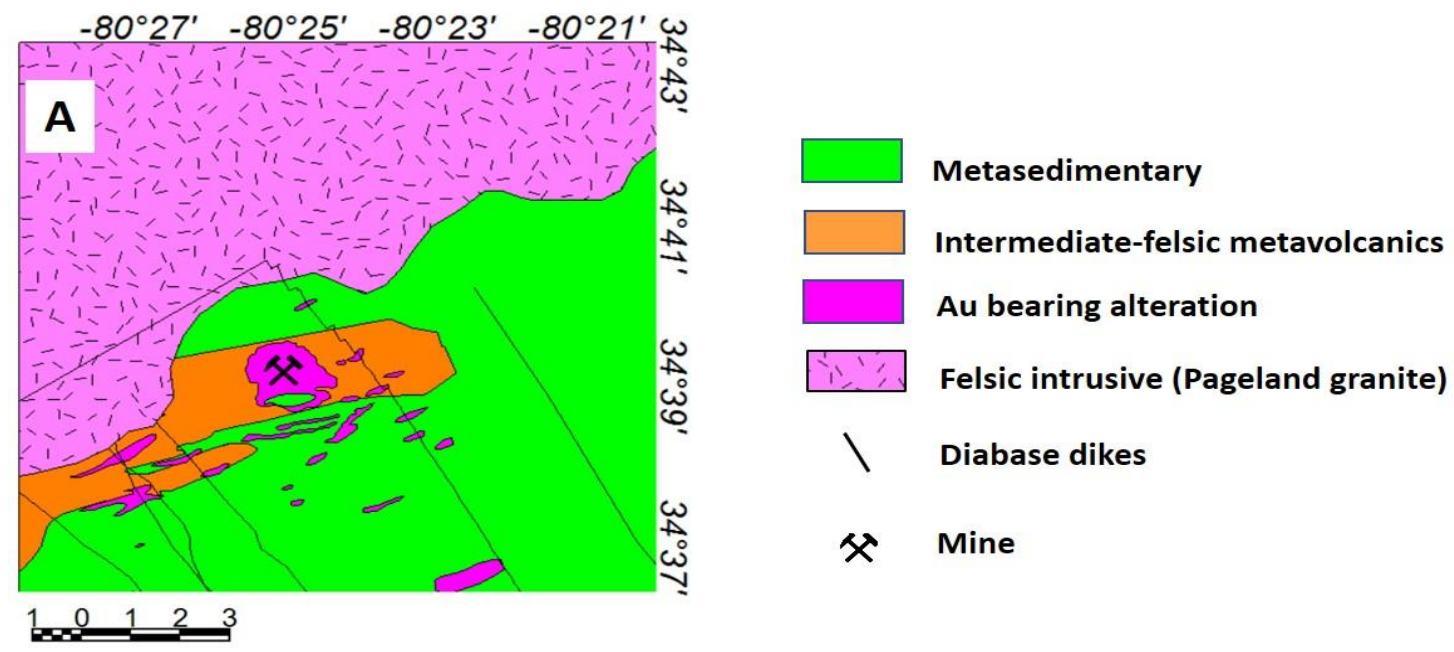

(km)
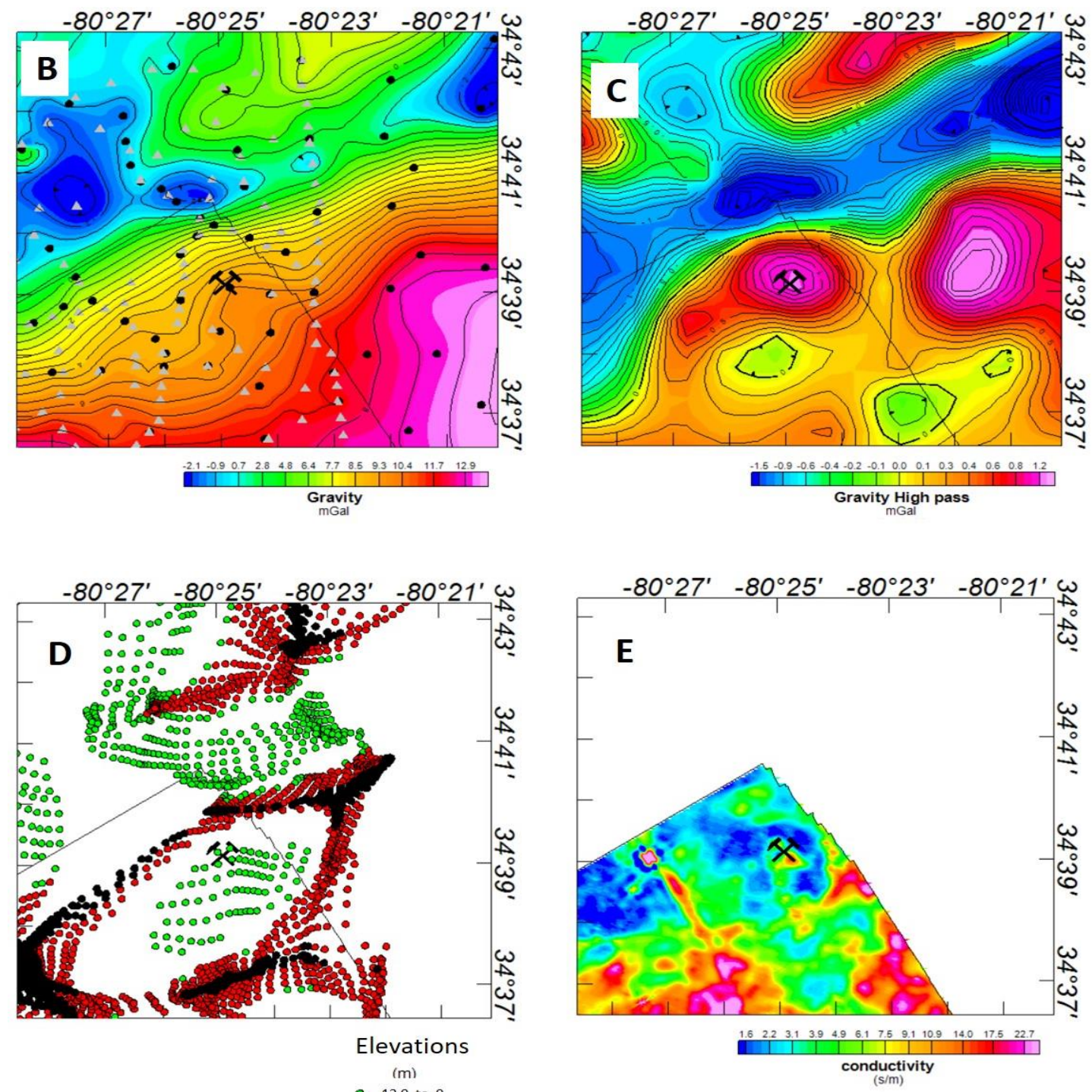

(m)

130 to 0
$-\quad 0$ to -500

0 to -500
-500 to -2050 

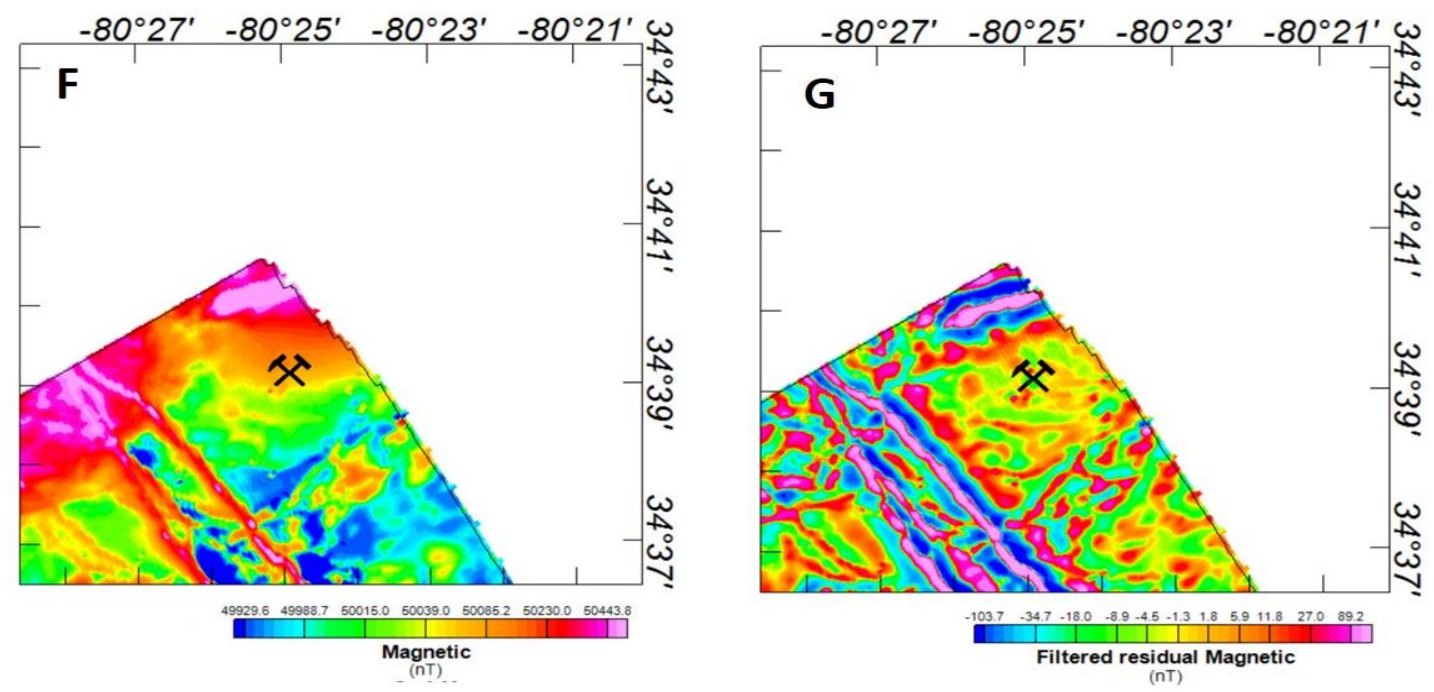

Figure 3.7: Brewer mine area. See Figure 3.5a for location. A) Geological bed rock map at $300 \mathrm{ft}(91 \mathrm{~m})$ above sea level (personal communication, John Jory, 2017). B) Bouguer anomaly map showing all gravity stations. Gray triangles - OceanaGold stations, black dots - Open-File stations (Daniels, 2005). C) Filtered residual Bouguer anomaly map (wavelength cutoff $=2 \mathrm{~km}$ ). D) Euler deconvolution of Bouguer anomaly map. Source elevations above sea level. Structural index: 0. E) EM conductivity map. F) Magnetic map. G) Filtered residual magnetic anomaly map (wavelength cutoff $=0.5 \mathrm{~km}$ ). 

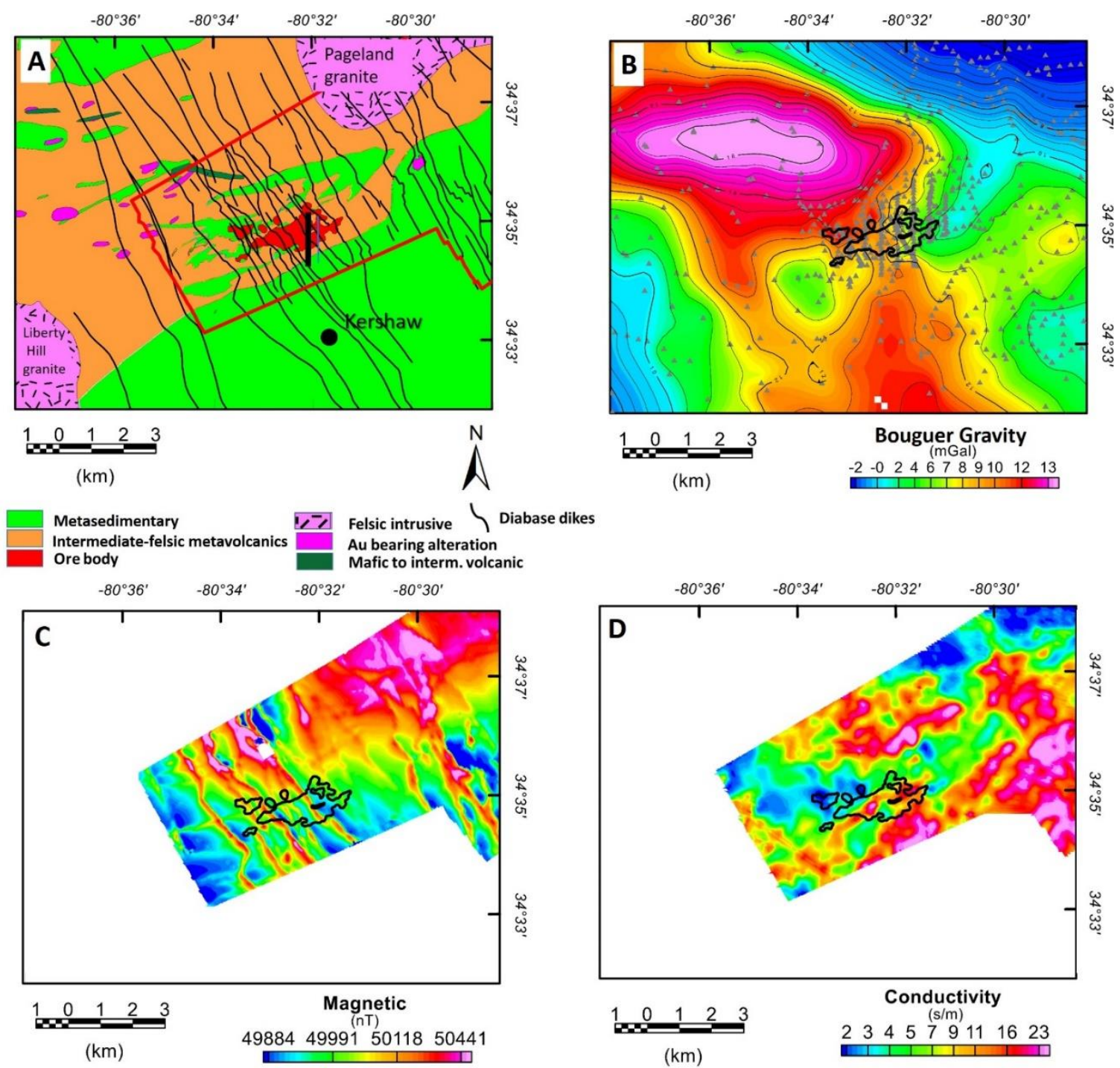

Figure 3.8: Haile mine area. See Figure 3.5a for location. A) Geological bed rock map at $300 \mathrm{ft}(91 \mathrm{~m})$ above sea level after SRK Consulting (2017). Black line over the ore zone is the profile location for Figure 3.12. B) Bouguer anomaly map showing all gravity stations. C) Total magnetic intensity map. D) EM conductivity map. Black outline is Haile Mine ore body extent. 


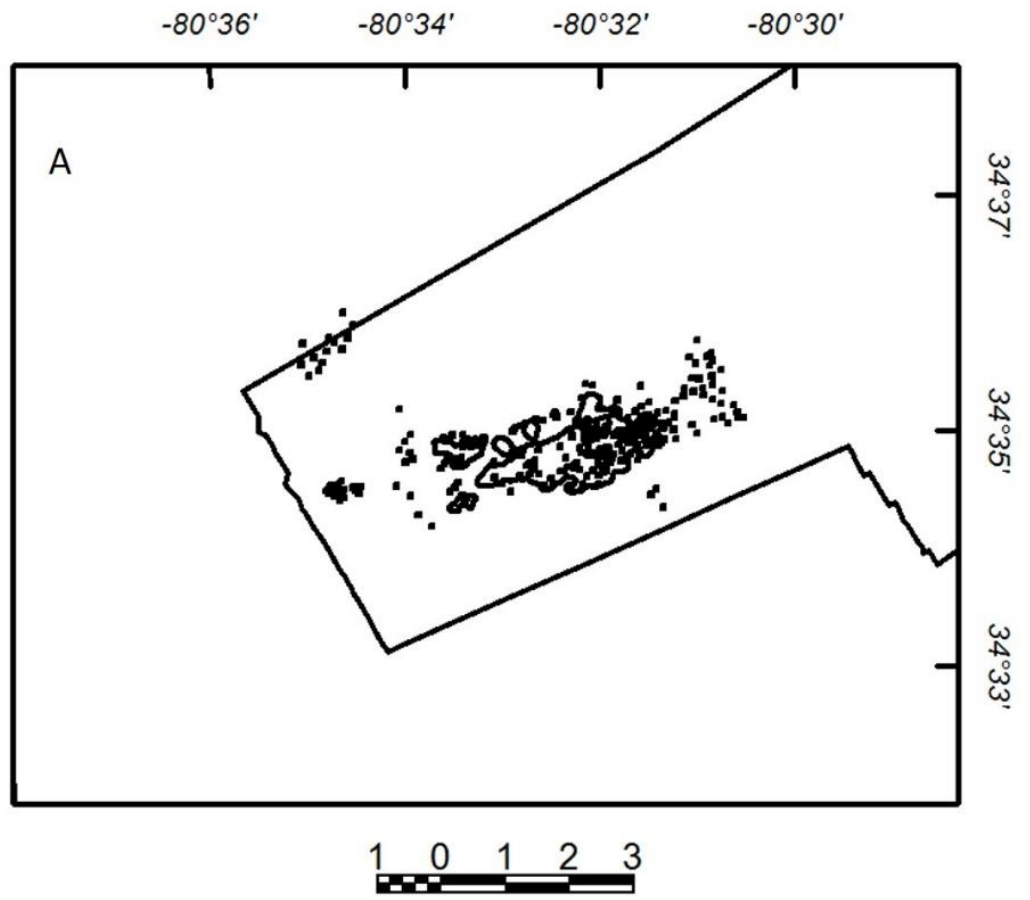

$(\mathrm{km})$

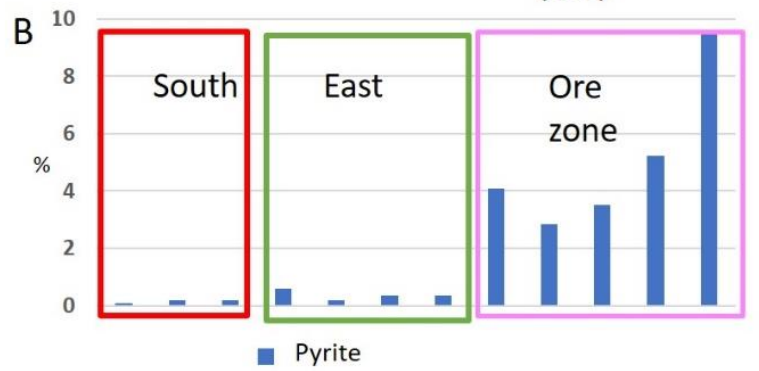

C
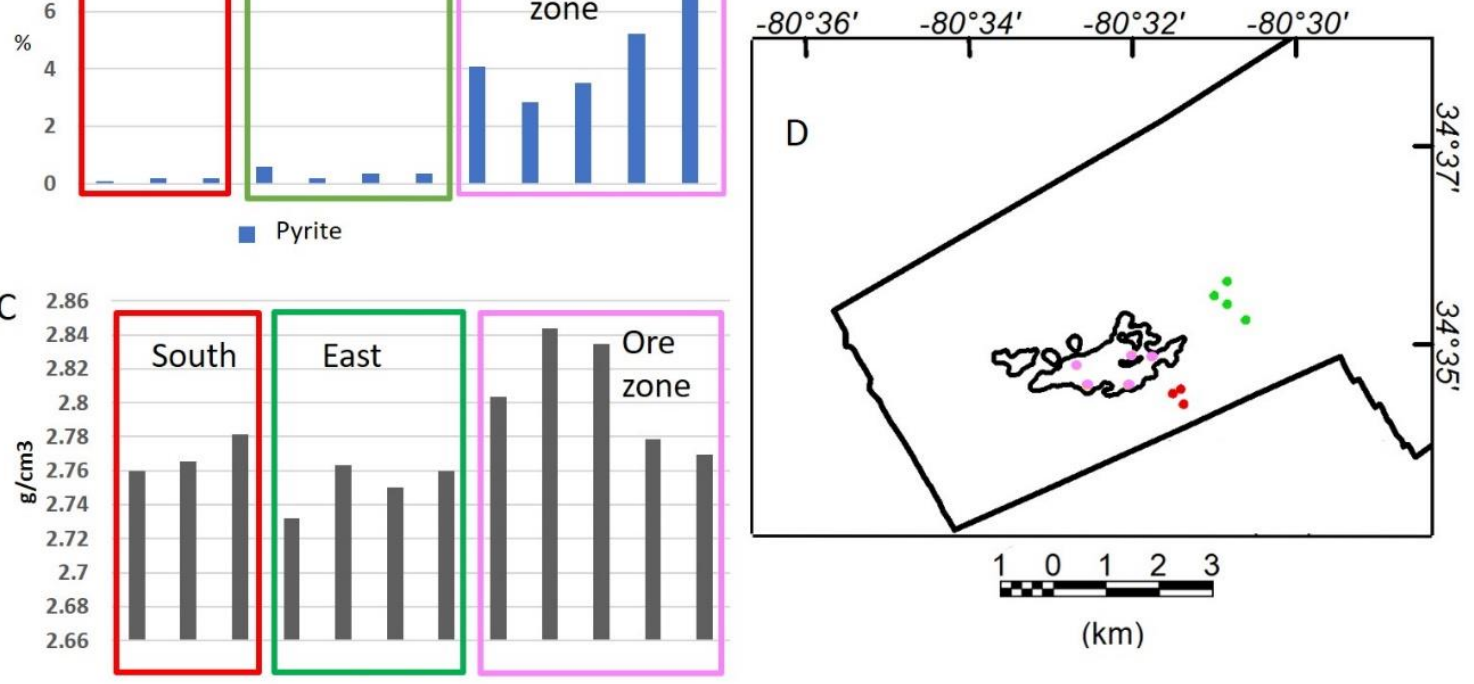

Figure 3.9: Random wells in Haile mine area. Location same as Figure 8. The polygon outlines the southwest area covered by the helicopter survey. Black dots are drill wells. B) Pyrite percentages inside, east, and south of the Haile ore zone. C) Rock densities $(\mathrm{g} / \mathrm{cm} 3)$ inside, east, and south of the Haile ore zone. Black outline is Haile Mine ore body extent. D) Pink dots are drill wells in the ore zone. Red dots are south of the ore zone. Green dots are east of the ore zone. 


\section{Pyrite \%}

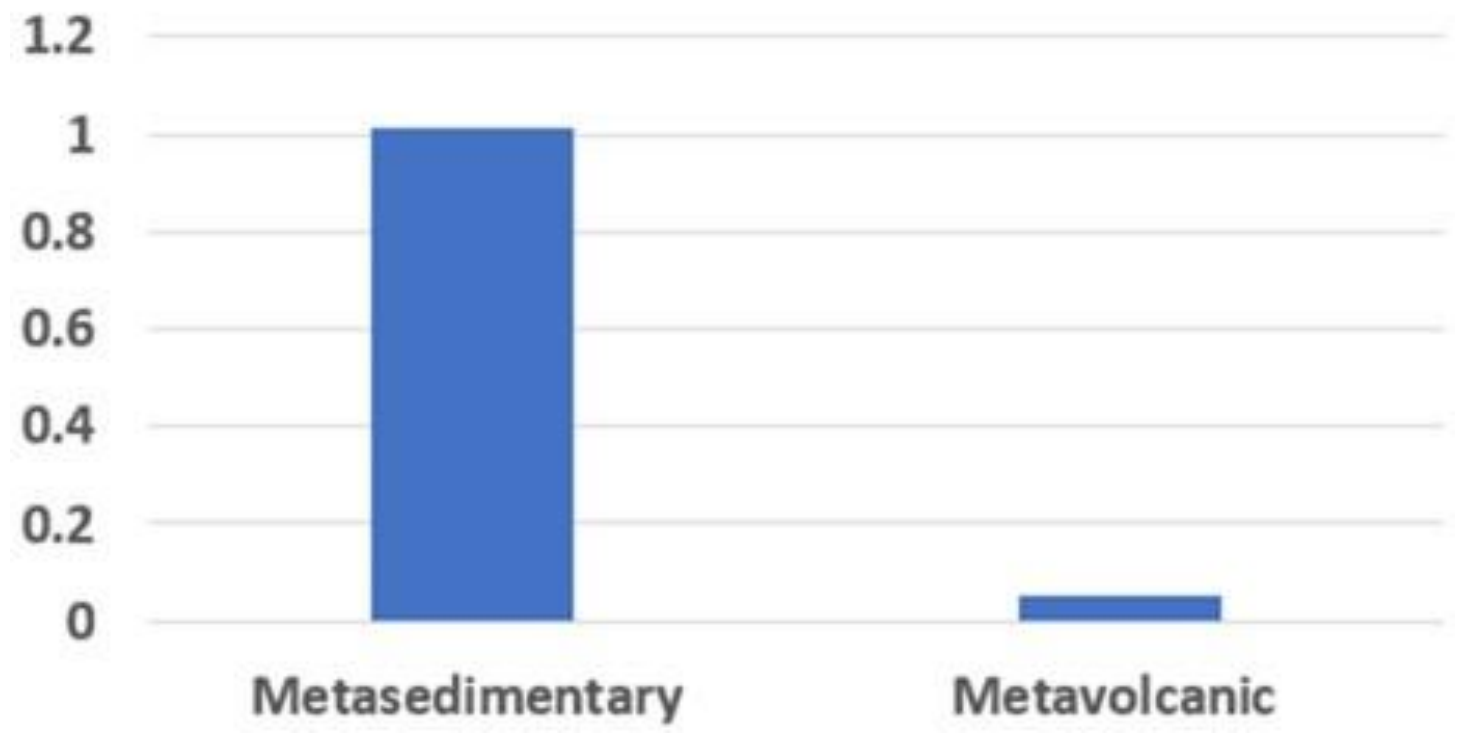

Figure 3.10: Average percentages of pyrite in metasedimentary and metavolcanic rocks for 40 samples in Haile ore zone. 

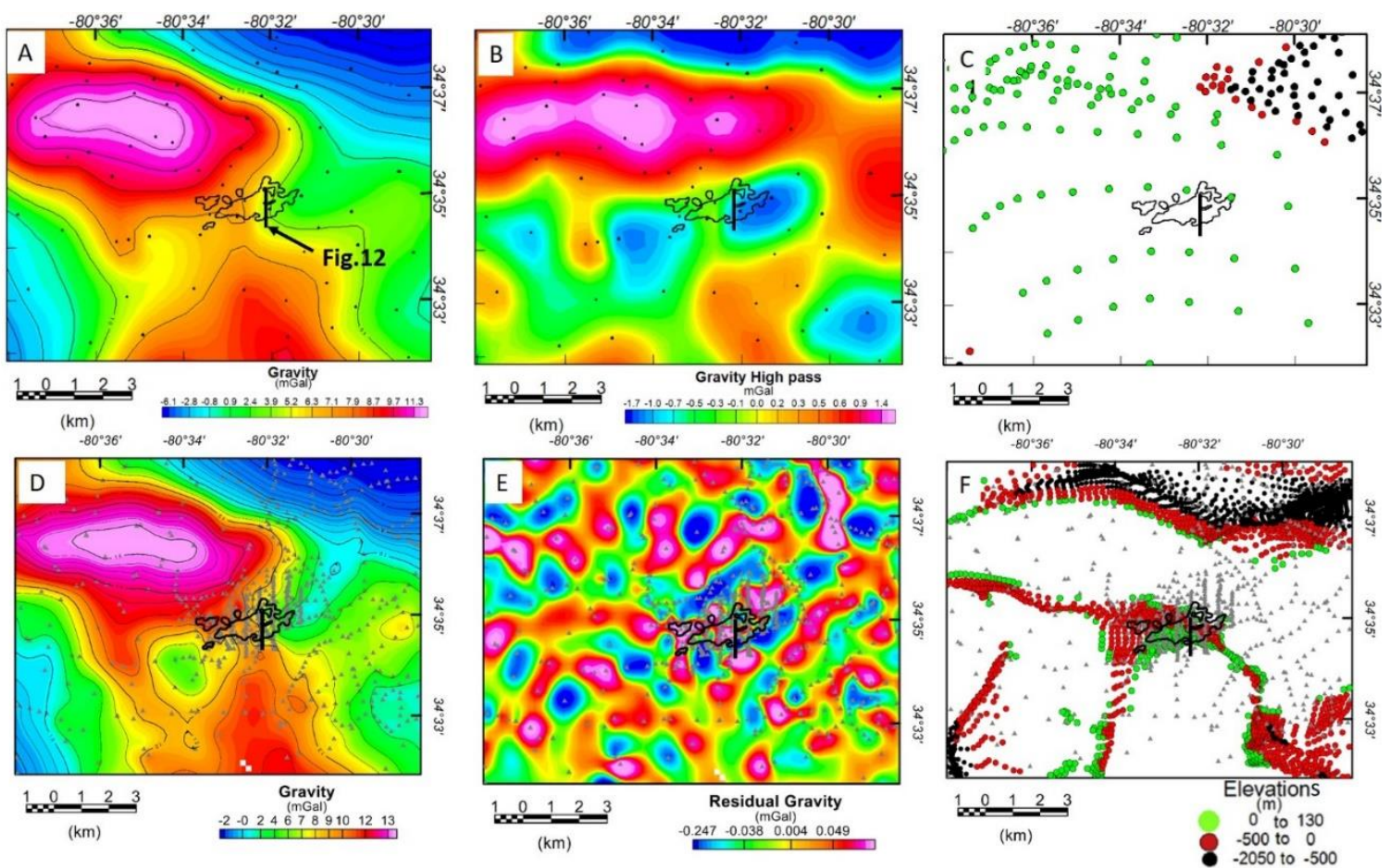

Figure 3.11: Haile mine area low resolution gravity (A, B, C) versus high resolution gravity (D, E, F). See Figure 3.5a for location. A, B, and C use only USGS regional gravity observation points. D, E, and F use both the high resolution OceanaGold and the USGS regional gravity observations. Black outline is Haile Mine ore body extent. A) Bouguer gravity anomaly map using low resolution regional USGS gravity. Black line over the ore zone is the profile location for Figure 3.12. B) High pass of regional gravity (wavelength with cutoff $=2 \mathrm{~km}$ ). C) Euler deconvolution solution map for regional data. D) Bouguer gravity anomaly map (USGS plus high resolution OceanaGold). E) High pass of high resolution gravity. F) Euler deconvolution solution map for high resolution gravity observations. 


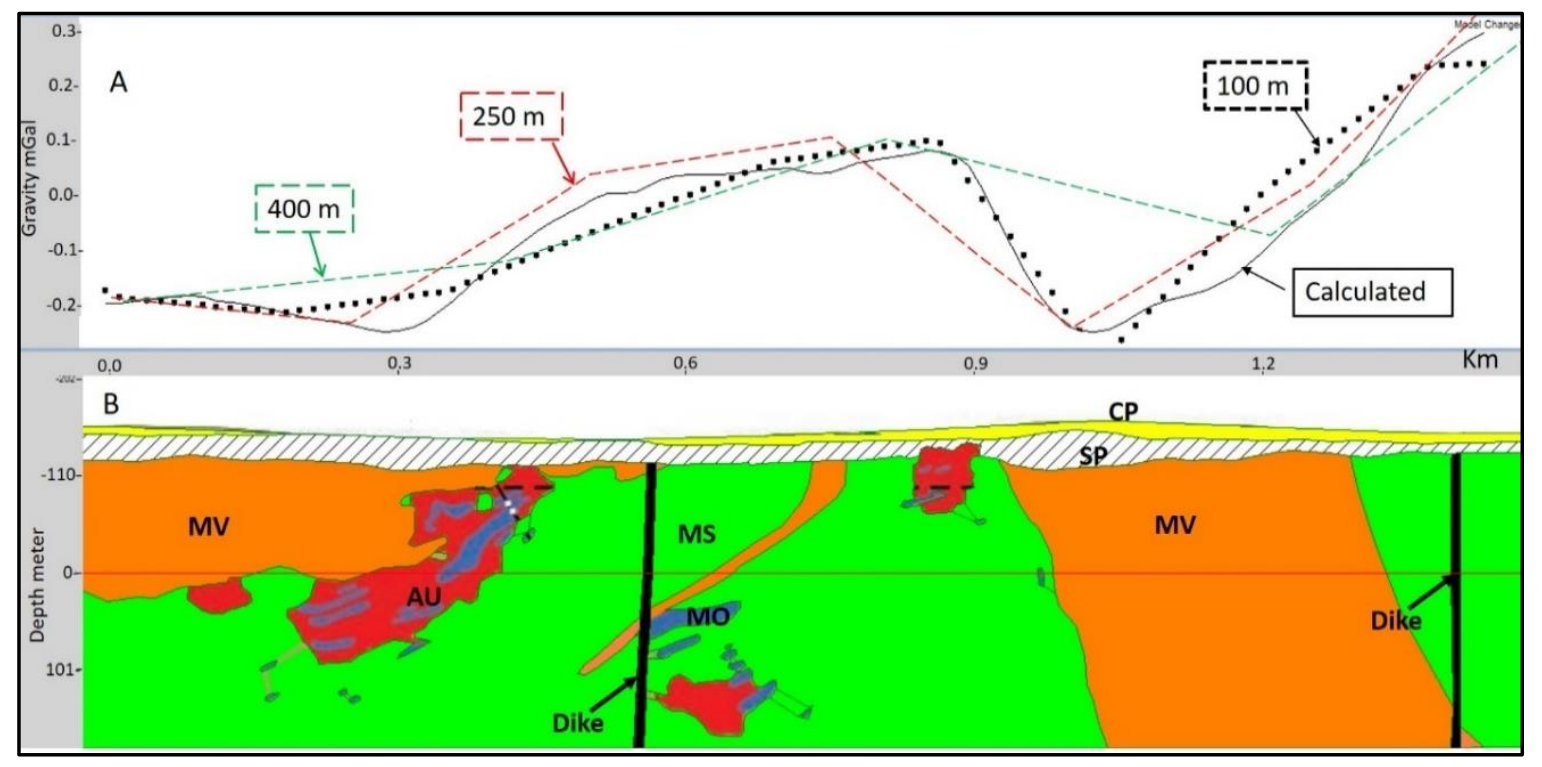

Figure 3.12: 2-D forward density model for Haile mine profile located in Figure 3.11A after Alarifi et al. (2019). A) Calculated model gravity (solid line from Alarifi et al., 2019), and observed residual gravity at station spacings of $100 \mathrm{~m}$ (black dotted line), 250 $\mathrm{m}$ (red dashed line) and $400 \mathrm{~m}$ (blue dashed line). B) Drill core constrained geology after Mobley et al. (2014) and SRK Consulting (2017). MS (green) is a metasedimentary unit. $\mathrm{MV}$ is a metavolcanic unit. AU (red) is gold bearing unit. MO (blue) is molybdenite, SP is saprolite. CP is coastal plain sediments.

Table 3.1: Density values from OceanaGold laboratory measurements of 49,183 samples from 448 drill holes in 2016

\begin{tabular}{|c|c|c|}
\hline Unit & Density $\mathbf{( g / \mathbf { c m } ^ { \mathbf { 3 } } )}$ & $\mathrm{N}$ \\
\hline Metasedimentary (MS) & $2.76 \pm 0.18$ & 36061 \\
\hline Metavolcanics (MV) & $2.69 \pm 0.20$ & 13091 \\
\hline Gold bearing (AU) & $2.73 \pm 0.05$ & 31 \\
\hline
\end{tabular}


Table 3.2: Ore mineral and host rock densities $\left(\mathrm{g} / \mathrm{cm}^{3}\right)$ and magnetic susceptibilities $\left(10^{-6}\right.$ SI) after Airo \& Säävuori 2013.

\begin{tabular}{l|l|l|l|l}
\hline Mineral & \multicolumn{2}{|l|}{ Density $\mathbf{g} / \mathbf{c m}^{3}$} & \multicolumn{2}{l}{ Susceptibility $\mathbf{1 0}^{-6}$} \\
\hline Sulfides / Oxides & Range & Average & Range & Average \\
\hline Chalcopyrite & $4.1-4.3$ & 4.2 & $300-400$ & \\
Pentlandite & 5.02 & 4.8 & $-6-100$ & \\
Pyrite & $4.5-4.8$ & 4.65 & $\begin{array}{l}-6000 \\
\text { up to } 6000000\end{array}$ & \\
Pyrrhotite & & 5.18 & $1000000-15000000$ & 3000000 \\
Magnetite & & 5.26 & $1300-7000$ & \\
Hematite & & & & up to 3000000 \\
Maghemite & & & $1000-8000$ & \\
Ilmenite & & & \\
Host rocks & $2.3-3.11$ & 2.61 & $500-80000$ & \\
Felsic igneous & $2.09-3.17$ & 2.79 & $1000-100000$ & \\
Mafic igneous & $2.78-3.37$ & 3.15 & $10000-100000$ & \\
Ultramafic rocks(peridotite) & &
\end{tabular}

Table 3.3: Resistivity (Ohm-M) measurement values from OceanaGold

\begin{tabular}{|c|c|c|}
\hline Unit & Resistivity (Ohm-m) & N \\
\hline Metasedimentary & $1814 \pm 679$ & 22 \\
\hline Metavolcanics & $2366 \pm 1315$ & 18 \\
\hline
\end{tabular}

Table 3.4: Magnetic susceptibility (cgs) $\times 10^{-6}$ measurements from OceanaGold

\begin{tabular}{|c|c|c|}
\hline Unit & Magnetic Susceptibility (CGS) $\times 10^{-6}$ & N \\
\hline Metasedimentary & $9.03 \pm 8.4$ & 22 \\
\hline Metavolcanics & $8.99 \pm 5.22$ & 18 \\
\hline
\end{tabular}




\section{CHAPTER 4}

\section{CONCLUSIONS AND DISCUSSION}

The Carolina slate belt (CSB) is interpreted as a volcanic arc with a complex history. The CSB displays evidence of ocean plate subduction beneath ocean plate, active continental back-arc volcanism, and a history of shifting volcanic centers (Crowe, 1995; Hibbard and others, 2002; Rogers and Coleman, 2010). All the gold deposits in the Carolina terrane are hosted in similar geologic settings near the contact between metamorphosed volcaniclastic and metamorphosed sedimentary rocks of Neoproterozoic to Early Cambrian age (Worthington and Kiff, 1970). All gold deposits were recognized as epithermal, disseminated gold-pyrite deposits (Feiss et al., 1993; Ayuso et al., 2005; and Mobley et al. 2014). The ore bodies trend east-northeast, subparallel to the structural trend of the Carolina terrane (SRK Consulting, 2017). The Carolina terrane contains lowgrade meta-igneous and meta-sedimentary rocks of Neoproterozoic to Late Cambrian age (Secor et al., 1983).

In the absence of seismic refraction data, the gravity, electromagnetic and magnetic data can be used to determine the subsurface conditions at, and in the vicinity of, a site. Active hydrothermal systems cause significant physical changes to their host rocks and the resultant anomalies are adjustable and amenable to delineation and detection by geophysical techniques (Allis 1990). Geophysical applications are significantly effective when used in conjunction with a drilling or core drilling program. Each geophysical method has its limitations and advantages. The combination of two or 
more geophysical techniques in an integrated interpretation results in a reduction of the degree of uncertainty and ambiguity. The gravity method is often integrated with magnetic and electromagnetic methods during integrated base-metal surveys (Telford et al., 1976). Common ore minerals (magnetite, pyrrhotite and pyrite) have densities above $4.0 \mathrm{~g} / \mathrm{cm} 3$, so that their presence can increase the bulk density of a rock (e.g., Airo, 2015). The magnetic method has much in common with the gravity method, but the magnetic field is much more complicated and variable. The magnetic field is bipolar, non-vertical in direction, with sharp local anomaly variations. The gravity field is unipolar, vertical in direction, with smoother and regional anomalies (Telford et al., 1976). Pyrite is non-magnetic, while quartz, calcite and dolomite are negative-magnetic and tend to decrease the rock susceptibility, table 4.1 (Sharma, 1997). Low resistivity is associated with sulfide minerals, and increased porosity in sericitized rocks, and resistivity highs are associated with silicification and intrusions (Hoover et. al., 1992; Ford et al., 2007). In the metavolcanics unit (Persimmon Fork) quartz are dominant with lesser muscovite, biotite, calcite, and chlorite (SRK Consulting, 2017). The main minerals within the metasedimentary unit are quartz, pyrite (generally less than $10 \%$ ), mica (up to 50\%), pyrrhotite, and chlorite, (Dennis and Wright, 1997; Hibbard et al., 2002; Mobley et al., 2014).

There have been very few geophysical case studies published about the delineation and exploration of epithermal gold deposits, due to commercial confidentiality. This research focuses on calibration of new and old drill core data being collected for Romarco Minerals Inc. and Oceanagold Inc., as well as high resolution gravity, and airborne electromagnetic and magnetic data owned by Oceanagold Inc. This 
research is the first geophysical assessment that uses multiple geophysical imaging methods to interpret the gravity and magnetic fields over the Carolina slate belt and important gold mine areas in South Carolina.

We use recently collected high resolution gravity data, and drill cores at the mineralized zone at the Haile mine, as constraints along two profiles with known geology from multiple drill cores to develop plausible two-dimensional cross-section models that better image the positive residual density anomalies over ore bodies. Surficial geology was used to help constrain the model parameters. Then we test whether the short wavelength residual gravity could be correlated with rock units and mineralized zones, and hence whether high resolution gravity could be useful as an exploratory tool. In this study we used physical property measured and mineral concentrations assessed for around 50,000 samples from around 450 drillholes in the Haile Mine area from OceanaGold.

At Haile mine, the filtered residual Bouguer gravity anomaly map shows a correlation between positive anomalies and the mineralized ore zone in the Haile mine area. The entire amplitude range of the residual gravity anomaly map is less than 0.5 $\mathrm{mGal}$, so a high precision densely spaced ground gravity survey was required to achieve this resolution. Similar correlations between positive anomalies and the ore zones are observed in the first vertical derivatives of Bouguer gravity and tilt derivatives of the filtered residual gravity. Densities and mineral concentrations from drillcores show that pyrite is the main mineral increasing sample density. Resistivity highs are associated with silica content and pluton intrusion. 
The low magnetic susceptibility values for the metasedimentary $9.03 \times 10^{-6}$ [cgs] and metavolcanic $8.99 \times 10^{-6}$ [cgs] units in the Haile mine area correlate with low mapped TMI values relative to the highly magnetic gabbro, granites, diabase dikes 4200 $\mathrm{x} 10^{-6}[\mathrm{cgs}]$ and even lamprophyre dikes $344 \times 10^{-6}$ [cgs]. The mineralized ore zones at Haile and Brewer exhibit no distinctive magnetic anomalies in contrast to the positive residual gravity and conductivity anomalies associated with the ore zones. In general, magnetic susceptibilities in granites range widely from $1 \times 10^{-5}$ [cgs] in leucocratic granites up to $1.3 \times 10^{-3}$ [cgs] in some granodiorites and tonalites and $200 \times 10^{-5}$ [cgs] in some gabbros (e.g., Rochette et al., 1992; Tarling and Hrouda, 1993; Gleizes et al., 1993; Magalhães et al., 1994; Borradaile and Henry, 1997; Bouchez, 1997; Lillie, 1999; Gregorová et al., 2003; Aydin et al., 2007). In North Carolina, the natural remnant magnetization of the Pee Dee gabbro averages $6.9 \times 10^{-3}$ [cgs] and the Lilesville granite averages $1.5 \times 10^{-5}$ [cgs] (Barton and Brown 1983). Magnetic, ilmenite, hematite and pyrrhotite have particularly high magnetic susceptibilities (table 3.3) that can produce high induced and remanent magnetic anomalies. The most abundant magnetic mineral in the granite plutons is magnetite (Barton and Brown 1983). The gabbros contain magnetite, ilmenite, hematite, pyrite and pyrrhotite (McSween et al., 1984; McSween et al., 1991). The diabase dikes have a high ratio of modal titanomagnetite to ilmenite and contain Fe-rich titanomagnetites (Ragland 1990; Warner and Wasilewski 1990). The high-resolution magnetic data also provided the first magnetic maps of Alleghenian lamprophyre intrusions in the southeastern United States (this dissertation).

At Brewer mine, the gold mineralization is associated with zones of strong silicification and quartz-sericite-pyrite alteration (Minard, 1971; Nystrom, 1973). The 
hydrothermal alteration system at Brewer mine has been reported by Lu et al., 1992 as a near-circular shape. At first, no obvious correlation can be observed between the Bouguer gravity or total magnetic intensity fields and hydrothermal alteration halo at Brewer mine. But the residual gravity and magnetic anomaly maps, as well as conductivity map, show a small aeromagnetic anomaly in the immediate vicinity of the altered area that correlates with high resistivity and a pronounced positive gravity anomaly. There are many rounded features in the high pass filter of the gravity map that could indicate a possible ring fractured zone. These interpreted ring features could be correlated with what has been reported by Feiss and Vance (1995).

Most hydrothermal alteration destroy magnetite and cause demagnetisation anomalies (Airo and Mertanen, 2008). The total magnetic intensity (TMI) maps are dominated by the NW-trending Jurassic dikes. Both state and high-resolution magnetic surveys show no clear signal associated with the ore zones. This may be due to 1) the ore's magnetite being affected by hydrothermal alteration;2) the low susceptibility of quartz and pyrite (table 4.1) that is associated with the mineralization zones; and 3) the stronger magnetic signal from the mafic dikes that dominates the magnetic field. The aeromagnetic map of the wide greenstone belt in South Carolina shows the weakly magnetic, the Carolina slate belt.

The tilt derivative and shaded relief of magnetic maps illuminate the edge contact of Carboniferous granites and the dikes. The Carolina slate belt is bordered in the southeast of the Barite Hill mine by a linear pattern of more highly magnetic anomaly belonging to the Modoc shear/fault zone. The fault zone is represented by magnetic and gravimetric linear indications with the main strike of NE. The Modoc faults are defined 
as almost linear magnetic gradients in short and long-wavelength magnetic data, and they are tens of kilometers long. Euler deconvolution of the Bouguer gravity field indicated maximum depths of about $2000 \mathrm{~m}$ below sea level for density sources in the Modoc shear zone (figures 3.5.f and 3.6.f) and suggest that the zone is steeply dipping, but do not resolve a clear dip direction. Euler deconvolution of the Bouguer gravity field for density contrasts at the margins of the Alleghenian granite plutons indicated maximum depths of about 2000 to $5000 \mathrm{~m}$ below sea level, but do not show clear dip directions for the margins. However, gravity anomalies and surface geology for the Barite Hill granite are consistent with a convex upward roof and a deep central feeder conduit. 2D forward density models of the Liberty Hill and Pageland granites demonstrate laccolith geometries with eroded roofs, near surface very shallow inward dipping margins to deeper higher angle conduit margins (Tuten, 2013).

Several gold occurrences in the Carolina slate belt are found along a strongly residual gravity anomaly and are magnetically weak. These are associated with intensive electrical conductivity over the mineralized zones at Haile. Also, the rock densities tend to increase as the abundance of pyrite increases. The densities grow with the proportion of mafic silicates, so that more silica-rich rock types appear at lower densities and mafic rock types have higher densities, while gabbro and ultramafic rocks have the highest. To find the probability of detecting a geophysical anomaly of the required minimum dimensions with a given survey spacing. We used the continuous geometric probability analysis of Agocs (1955), the probability to see a $1 \mathrm{~km} \times 3 \mathrm{~km}$ ore body such as the Haile ore zone with $100 \mathrm{~m}$ spacing is 0.964 . With the high densities and electrical conductivity associated with the ore zones, high resolution land gravity and airborne electromagnetic 
surveys are recommended as initial geophysical exploration methods in the Carolina slate belt.

Table 4.1: Densities of rocks and minerals (Sharma, 1997)

\begin{tabular}{|ll|}
\hline & Density (wet) \\
Rock type or mineral & $\left(\times 10^{3} \mathrm{~kg} / \mathrm{m}^{3}\right)$ \\
\hline Sand & $1.6-2$ \\
Moraine & $1.5-2$ \\
Sandstones (Mesozoic) & $2.15-2.4$ \\
Sandstones (Paleozoic and older) & $2.35-2.65$ \\
Quartzite & $2.60-2.70$ \\
Limestone (compact) & $2.5-2.75$ \\
Shales (younger) & $2.1-2.6(2.4)^{\circ}$ \\
Shales (older) & $2.65-2.75(2.7)$ \\
Gneiss & $2.6-2.9(2.7)$ \\
Basalt & $2.7-3.3(2.98)$ \\
Diabase & $2.8-3.1(2.96)$ \\
Serpentinite & $2.5-2.7(2.6)$ \\
Gypsum & 2.3 \\
Anhydrite & 2.9 \\
Rocksalt & $2.1-2.4(2.2)$ \\
Zincblende & 4.0 \\
Chromite & $4.5-4.8$ \\
Pyrite & $4.9-5.2$ \\
Hematite & 5.1 \\
Magnetite & $4.9-5.2(5.1)$ \\
Galena & $7.4-7.6$ \\
Granite & $2.52-2.81(2.67)$ \\
Granocliorite & $2.67-2.79(2.72)$ \\
Syenite & $2.63-2.90(2.76)$ \\
Quartzdiorite & $2.68-2.96(2.81)$ \\
Gabbro & $2.85-3.12(2.98)$ \\
Peridotite & $3.15-3.28(3.23)$ \\
Dunite & $3.20-3.31(3.28)$ \\
Eclogite & $3.34-3.45(3.39)$ \\
\hline \hline Note: & \\
o Figures in parentheses are taken to be average values. \\
\hline
\end{tabular}




\section{REFERENCES}

Agocs, W. B., 1955. Line Spacing Effect and Determination of Optimum Spacing Illustrated by Marmora, Ontario, magnetic anomaly. Geophysics, 20, 871-885.

Airo, M.-L., 2015, Geophysical signatures of mineral deposit types- Synopsis. Geological Survey of Finland, Special Paper 58, 9-70

Airo, M-L, and Mertanen, S., 2008, Magnetic signatures related to orogenic gold mineralization, Central Lapland Greenstone Belt, Finland. Journal of Applied Geophysics, 64, 14-24

Airo, M.-L., Hyvönen, E., Lerssi, J., Leväniemi, H. and Ruotsalainen, A., 2014, Tips and tools for the application of GTK's airborne geophysical data. Geological Survey of Finland, Report of Investigation 215

Alarifi, S. S., 2017. High resolution Gravity, helicopter Magnetic, and Electromagnetic study, Haile Gold Mine, South Carolina. (Master's thesis). Retrieved from http://scholarcommons.sc.edu/etd/4135

Alarifi, S. S., Kellogg, J. N., and Ibrahim, E., 2019. Gravity, aeromagnetic and electromagnetic study of the gold and pyrite mineralized zones in the Haile Mine area, Kershaw, South Carolina. Journal of Applied Geophysics, 164,117129.

Allard, M., 2007, On the origin of the HTEM species, in Milkereit, B., Ed., Proceedings of Exploration 07: Fifth Decennial International Conference on Mineral Exploration, p.355-374.

Allard, G.O. \& Whitney, J.A., 1994, Geology of the Inner Piedmont, Carolina Terrane, and Modoc Zone in Northeastern Georgia. Project Report 20. Georgia Geological Survey, Environmental Protection Division, Georgia, United States, 36pp.

Arribas A. Jr, 1995.Characteristics of high-sulfidation epithermal deposits, and their relation to magmatic fluid. In: Thompson JFH (ed), Magmas, Fluids, and Ore Deposits. Short Course Series Vol.23: Mineralogical Association of Canada,419 $-454$

Arribas, A., Hedenquist, J. W., Itaya, T., Okada, T., Concepcion, R. A., Garcia, J. S., 1995.Contemporaneous formation of adjacent porphyry and epithermal $\mathrm{Cu}-\mathrm{Au}$ deposits over $300 \mathrm{Ka}$ in Northern Luzon, Philippines. Geology 23:337-340 
Aydın, A., Feré, E.C., Aslan, Z., 2007. The magnetic susceptibility of granitic rocks as a proxy for geochemical composition: example from the Saruhan granitods, NE Turkey. Tectonophysics 441, 85-95.

Ayuso, R. A., Wooden, J. L., Foley, N. K., Seal II, Robert R., and Sinha, A. K., 2005.U $\mathrm{Pb}$ Zircon Ages and $\mathrm{Pb}$ Isotope Geochemistry of Gold Deposits in the Carolina Slate Belt of South Carolina. USGS Staff -- Published Research. 338. http://digitalcommons.unl.edu/usgsstaffpub/338

Balinsky, M., 1994, Field evidence for late Mesozoic and/or Cenozoic reactivation faulting along the Fall Line near Camden, South Carolina: Unpublished M.S. thesis, Columbia, University of South Carolina, 25 p.

Barker, C. A., Secor, D. T., Jr., Pray, J. R., and Wright, J. E., 1998, Age and deformation of the Long town meta granite, South Carolina Piedmont: A possible constrain on the origin of the Carolina terrane: Journal of Geology, v.106, p. 713-725.

Barton, C., and Brown, L., 1983. Paleomagnetism of Carboniferous Intrusions in North Carolina. Journal of Geophysical Research, vol. 88, no. B3, pages 2327-2335.

Bell, H., III. 1980. Preliminary geologic map and section of the Kershaw Quadrangle, Kershaw and Lancaster Counties, South Carolina: U.S. Geological Survey Open File Report 80-226.

Bell, H., III, 1982. Strata-bound sulfide deposits, wall-rock alteration, and associated tin bearingminerals in the Carolina slate belt, South Carolina and Georgia: ECONOMIC GEOLOGY, v. 77, p. 294-311.

Bell, H. III., and Popenoe, P., 1976. Gravity studies in the Carolina slate belt near the Haile and Brewer mines, North-central South Carolina. Journal of Research of the U. S. Geological Survey, v. 4.

Bell, H., Butler, J., Howell, D., and Wheeler, W., 1974, Geology of the Piedmont and Coastalplain near Pageland, South Carolina and Wadesboro, North Carolina. Carolina Geol. Soc. Field trip guide.

Bell H, III., Books Kg., Daniels Dl., Huff We Jr., and Popenoe P., 1980. Diabase Dikes in the Haile-Brewer Area, South Carolina, and Their Magnetic Properties. Geological Survey Professional Paper, Issue 1123, Parts 1-4.

Berry M., Mobley M., Gillon A., Yogodzinski M., and Bates C., 2016, A Neoproterozoic epithermal gold deposit - The Haile Gold Mine, South Carolina, USA. Geological Societyof America Field Guide 42, p.1-8. 
Bhattacharya B. K., 1965: Two-dimensional harmonic analysis as a tool for magnetic interpretation. Geophysics, 30, 829-857.

Blakely, R.J., 1995, Potential Theory in Gravity and Magnetic Applications, Cambridge University Press, New York.

Borradaile, G.J., Henry, B., 1997. Tectonic applications of the magnetic susceptibility and its anisotropy. Earth-Science Reviews 42 (1-2), 49-93.

Bouchez, J.L., 1997. Granite is never isotropic: an introduction to AMS studies of granitic rocks. In: Bouchez, J.L., Hutton, D.H.W., Stephens, W.E. (Eds.), Granite: from Segregation of Melt to Emplacement Fabrics. Petrology and Structural Geology, vol. 8. Kluwer Publishing Co., Dordrecht, pp. 95-112.

Butler, J.R., and Secor, D.T., Jr., 1991, The central Piedmont, in Horton, W., and Zullo, V., eds., The Geology of the Carolinas: Knoxville, University of TennesseePress, p. 59-78.

Carmichael, R. S., 1989, Practical handbook of physical properties of rocks and minerals, CRC Press; 1st Edition

Clark, S.H.B., Greig, D.D., and Bryan, N.L., 1992. A preliminary report on the geology of the volcanic rock-hosted Barite Hill gold deposit, Carolina slate belt:

Geological Society of American Abstracts with Programs, v.24, no.2, p.8-9.

Clark, S.H.B., Gray, K.J., and Back, J.M., 1999. Geology of the Barite Hill gold-silver deposit in the southern Carolina slate belt: ECONOMIC GEOLOGY, v. 94, p. 1329-1346.

Cook F. A., Brown L. D., Kaufman S., Oliver J. E., and Petersen T. A., 1981. COCORP seismic profiling of the Appalachian orogen beneath the Coastal Plain of Georgia. GSA Bulletin. V. 92 (10): 738-748.

Cooke, C.W., 1936. Geology of the Coastal Plain of Carolina U.S. Geol. Survey Bull.867, p.196.

Corbett, G.J., and Leach, T.M., 1998, Southwest Pacific Rim gold copper systems: Structure, alteration, and mineralization: Society of Economic Geologists Special Publication 6.

Daniels, D. L., 1974. Geologic interpretation of geophysical maps, central Savannah River area, South Carolina and Georgia: U.S. Geol. Survey Map GP-893,9 p. text.

Daniels, D.L., 2005. South Carolina Aeromagnetic and Gravity Maps and Data: a Web Site for Distribution of Data, Open-File Report 2005-1022; https://pubs.usgs.gov/of/2005/1022/. 
Daniels, D. L., Zietz, I., Popenoe, P., 1983. Distribution of subsurface lower Mesozoic rocks in the Southeastern United States as interpreted from regional aeromagnetic and gravity maps in Gohn GS ed Studies related to the Charleston South Carolina earthquake of 1886 tectonics and seismicity US Geological Survey Professional Paper 1313, p. K1- K24.

Dennis, A.J., 1995. The Carolina terrane in northwestern South Carolina: relative timing of events and recent tectonic models. In: Hibbard, J., van Staal, C., Cawood, P. (Eds.), Current Perspectives in the Appalachian-Caledonian Orogen. Geological Association of Canada Special Paper, vol. 41, pp. 173-189.

Dennis, A.J., 2016. Structural analysis of the Kiokee belt and its framing elements: Savannah River transect, in Doar, W.R., III, ed., Gold, Structures, and Landforms in Central South Carolina-Field Guides for the 2016 GSA Southeastern Section Meeting, Columbia, South Carolina: Geological Society of America Field Guide 42, p. 37-51, doi:10.1130/2016.0042(03).

Dennis, A.J., and Shervais, J.W., 1996, The Carolina terrane in northwestern South Carolina: Insights into the development of an evolving island arc: Geological Society of America Special Paper 304, p. 237-256.

Dennis, A.J., and Wright, J., 1997, The Carolina terrane in northwestern South Carolina, U.S.A.: Late Precambrian-Cambrian deformation and metamorphism in a peri Gondwanan oceanic arc. Tectonics, 16:460-473.

Dentith, M., Mudge, S., 2014. Gravity and magnetic methods. Geophysics for the Mineral Exploration Geoscientist. Cambridge University Press, Cambridge, pp. 85-190\&235-350 https://doi.org/10.1017/CBO9781139024358.007.

Dobrin, M.B., and Savit, C.H., 1988, Introduction to Geophysical Prospecting (4th ed.), New York, McGraw-Hill

Duff, P.D., and Kellogg, J.N., 2019. The Brunswick magnetic anomaly: Geophysical signature and geologic source: Geology, v. 47, p. 1-4, https://doi .org /10 .1130 /G45462.1

Duff, P.D., Kellogg, J., Howard, S., Horton, J.W., 2014. Imaging granites, igneous plutons and faults associated with continental collision and rifting using potential field, seismic, and well data, South Georgia rift basin and vicinity, Georgia. GSA Abstracts with Programs 46 (3).

Feiss, P. G., 1982. Ore deposits of the northern parts of the Carolina Slate Belt, North Carolina: Geological Society of America Special Paper, no. 191, p. 153-164. 
Feiss, P.G, and Vance, R.K., 1995. The Carolina terrane gold district: Rift-related volcanogenic gold deposits of the southern Appalachian Piedmont [abs]: Geological Society of America Abstracts with Programs, v. 27, p. A-27.

Feiss, G.P., Vance, R.K., and Wesolowski, D.J., 1993. Volcanic rock-hosted gold and base metal mineralization associated with Neoproterozoic-Early Paleozoic back arc extension in the Carolina terrane, southern Appalachian Piedmont: Geology, v. 21, p. 439-442.

Foley, N., Ayuso, R., and Seal II, R., 2001, Remnant Colloform Pyrite at the Haile Gold Deposit, South Carolina: A Textural Key to Genesis. Economic Geology, 69: 891 902

Ford, K., Keating, P., and Thomas, M. D., 2007, Overview of geophysical signatures associated with Canadian ore deposits, in Goodfellow, W.D., ed., Mineral Deposits of Canada: A Synthesis of Major Deposit-Types, District Metallogeny, the Evolution of Geological Provinces, and Exploration Methods: Geological Association of Canada, Mineral Deposits Division, Special Publication No. 5, p. 939-970.

Fullagar, P.D., and Butler, J. R., 1979. 325 to 265-my old granitic plutons in the Piedmont to the southeastern Appalachians: American Journal of Science, v.279, p. 161-165.

Fuller, B.D., 1967. Tow-dimentional frequency analysis and design of grid operators. Society Exploration Geophysics, V.2, P. 658-708

Gillon, K.A., Spence, W.H., Duckett, R.P., and Benson, C.J., 1995. Geology of the Ridgeway gold deposits, Ridgeway, South Carolina: Society of Economic Geologists GuidebookSeries, v. 24, p. 53-94.

Gillon, K.A., Mitchell, T.L., Dinkowitz, S.R., Barnett, R.L., 1998. The Ridgeway gold deposits - A window to the evolution of a Neoproterozoic intra-arc basin in the Carolina terrane, South Carolina: South Carolina Geology, 40, p. 29-70.

Gleizes, G., Nédélec, A., Bouchez, J.L., Autran, A., Rochette, P., 1993. Magnetic susceptibility of the Mont Louis - Andorra ilmenite -type granite (Pyrenees): a new tool for the petrographic characterization and regional mapping of zoned granite plutons. Journal of Geophysical Research: Solid Earth 98 (B3), 4317 4331.

Gunter WL, Padgett JP, 1988. Barite Hill: a new gold deposit in McCormick County, South Carolina. Geological Society of America Abstract 20(4): 268

Halik, R. S., 1983. Characterization of the Charlotte belt/Carolina slate belt boundary in the Silverstreet and Denny quadrangles, South Carolina: A stratigraphic, 
structural, and metamorphic study [M.S. thesis]: Columbia, University of South Carolina, $83 \mathrm{p}$.

Hannington, M. D., 1997, The Porphyry-Epithermal-VMS Transition: Lessons from the Iskut River Area, British Columbia, and Modern Island Arcs: SEG Newsletter, v. 29, p. 12-13.

Harris, M., Cassidy, J., Locke, C., Mauk, L., Stevens, M., and Vidanovich, P., 2005. Geophysical characteristics of the Karangahake epithermal deposit, Hauraki goldfield, New Zealand: Ministry of Economic Development, 2005 New Zealand Minerals and Mining Conference, Auckland, New Zealand, Proceedings, p. $115-124$.

Hatcher, R. D., Jr., and Zietz, I., 1980. Tectonic implications of regional aeromagnetic and gravity data from the southern Appalachians, in Wones, D. R., Ed., Proceedings, "the Caledonides in the USA": Department of Geological Sciences, Virginia Polytechnic Institute and State University, Memoir 2, p. 235-244.

Hayward, N., 1992, Controls on syntectonic replacement mineralization in parasitic antiforms, Haile Gold Mine, Carolina Slate Belt, U. S. A.: Economic Geology, v.87, p.91-112.

Hedenquist, J.W., and Lowenstern, J.B., 1994. The role of magmas in the formatio1; of hydrothermal ore deposits. Nature 370, 519-527.

Hibbard, J., 2000, Docking Carolina: Mid-Paleozoic accretion in the southern Appalachians: Geology; February 2000; v. 28, p. 127-130.

Hibbard, J.P., and Samson, S.D., 1995, Orogenesis exotic to the Iapetan cycle in the southern Appalachians: Geological Association of Canada Special Paper 41, p. 191-205.

Hibbard, J., Stoddard, E., and Secor, D., Dennis, J., 2002, The Carolina Zone: overview of Neoproterozoic to Early Paleozoic peri-Gondwanan terranes along the eastern Flank of the southern Appalachians: Earth-Science Reviews, v. 57, p. 299-339.

Hibbard, J., Pollock, J., Allen, J., and Brennan, M., 2008, The Heart of Carolinia: Stratigraphic and Tectonic Studies in the Carolina Terrane of Central North Carolina: Boulder, Colorado, Geological Society of America, Field Trip Guidebook, 54 p.

Hildenbrand, T., 1983, A filtering program based on two-dimensional Fourier analysis of geophysical data. United States Department of The Interior Geological Survey, open file report 83-237. 
Hinze, William J., von Frese, Ralph, R. B., and Saad, Afif, H., 2013. Gravity and Magnetic Exploration, Principles, Practices, and Applications, Cambridge University Press.

Hoover D., Klein D., and Campbell D., 1995, Geophysical Methods in Exploration and Mineral Environmental Investigations. USGS, open-file report 95-0831. https://pubs.usgs.gov/of/1995/ofr-95-0831/CHAP3.pdf.

Hopson, J.L. and Hatcher, R.D., 1988, Structural and stratigraphic setting of the Alto allochthon, northeast Georgia, Geological Society of America Bulletin, v. 100, p. 339-350.

Horton, W., and Dicken, C., 2001. Preliminary digital geologic map of the Appalachian Piedmont and Blue Ridge, South Carolina segment. USGS. Open-File Report 2001-298.

Horton, W., Drake, A., Rankin, D., 1989. Tectonostratigraphic terranes and their Paleozoic boundaries in the central and southern Appalachians. In: Dallmeyer, D. (Ed.), Terranes in the CircumAtlantic Paleozoic Orogens. Geological Society of America Special Paper, vol. 230, pp. 213-245

Huang, H., and Rudd, J., 2008. Conductivity-depth imaging of helicopter-borne TEM data based on a pseudolayer half-space model. Geophysics, V. 73, N. 3. $10.1190 / 1.2904984$

Hulse D., Lane T., and Crowl W., 2008. NI 43-101 Technical Report on the Haile Mine Project, Lancaster County, South Carolina

Huston D.L., 2000. Gold in volcanic-hosted massive sulfide deposits: distribution, genesis and exploration, in Society of economic Geologists Reviews in Economic Geology 13, 401-426.

Kiff, I.T., and Spence, W.H., 1987. Volcanogenic-epithermal-exhalative gold deposits of the Haile-type in the Carolina slate belt [abs.]: Geological Society of America Abstracts with Programs, v. 19, p. 394.

Kouzmanov, K., Moritz, R., von Quadt, A., Chiaradia, M., Peytcheva, I., Fontignie, D., Ramboz, C., and Bogdanov, K., 2009, Late Cretaceous porphyry $\mathrm{Cu}$ and epithermal $\mathrm{Cu}-\mathrm{Au}$ association in the Southern Panagyurishte District, Bulgaria: the paired Vlaykov Vruh and Elshitsa deposits: Mineralium Deposita, v. 44, p. 611-646.

Larson, A., and Worthington, J., 1989. Geophysical mapping at the Haile mine, Report for Piedmont Mining Company, January 1989, 22p. 
Legault, J. M., Niemi J., Brett J. S., Zhao S., Han Z., and Plastow G. C., 2016. Passive airborne EM and ground IP\resistivity results over the Romero intermediate sulphidation epithermal gold deposits, Dominican Republic. Exploration Geophysics, 47(3), 191-200.

Lillie, R., 1999. Whole Earth Geophysics: An Introductory Textbook for Geologists and Geophysicists (1st ed.), Prentice Hall, New Jersey.

Lu, C., Misra, K.C., Stonehouse, J.M., and Zwaschka, M.R., 1993. Geochemical signature of alteration at the Brewer gold mine, Jefferson, South Carolina: South Carolina Geology, no. 35, p. 37-54.

Macleod, I., Jones, K., and Dai, T., 1993. 3D analytic signals in the interpretation of total magnetic field data at low magnitude latitudes. Exploration Geophysics, 24(4), $679-688$.

Maddry, J.W., and Kilbey, T.R., 1995. Geology of the Haile gold mine selected mineral deposits of the Gulf Coast and southeastern United States: Part II. Gold deposits of the Carolina slate belt: Society of Economic Geologists Guidebook Series, v. 24, p. 147-172.

Magalhães, M.S., Dall'Agnol, R., Sauck, W.A., Luiz, J.G., 1994. Suscetibilidade magnética : um indicador da evolução petrológica de granitóides da Amazônia. Revista Brasileira de Geociencias 24 (3), 139-149.

Mauger, R.L., 1988. Geochemical evidence for sediment recycling from North Carolina (U.S.A.) minettes: Canadian mineralogist, v. 26, p. 133-141.

McSween, H. Y., Jr., 1972. An investigation of the Dutchmans Creek Gabbro, Fairfield County, South Carolina: South Carolina Div. Geology Geol. Notes, v. 16, no. 2, p. $19-42$.

McSween H. Y., Sando, T. W., Clark, S. R., Harden, J. T., Strange, E. A., 1984.The gabbro-metagabbro association of the Southern Appalachian Piedmont. American Journal of Science, v. 284, p.437-461.

McSween, H. Y., Speer J. A., and Fullagar P. D., 1991. Plutonic Rocks. In: Horton, J. W., Jr. \& Zullo, V.A. (eds), The geology of the carolinas: Carolina Geological Society fiftieth-anniversary volume. Knoxville: University of Tennessee Press, p109-126

McIntosh, S.M., Gill, J.P., and Mountford, A.J., 1999. The geophysical response of the Las Cruces massive sulphide deposit: Exploration Geophysics, v. 30, no. 3-4, p. 123-133.

Miller, H. G., and Singh, V., 1994, Potential field tilt - a new concept for location of potential field sources: Journal of Applied Geophysics, 32, 213-217. 
Mobley, R., Yogodzinski, G., Creaser, R., and Berry, J., 2014, Geologic history and timing of mineralization at the Haile gold mine, South Carolina; Economic Geology, v.109, pp.1863-1881.

Morgan, L., 2012, Geophysical Characteristics of Volcanogenic Massive Sulfide Deposits. Scientific Investigations Report 2010-5070-C, U.S. Geological Survey, Reston, Virginia, 115-131.

Morrell, A., Locke, C., Cassidy, J., and Mauk, J., 2011, Geophysical characteristics of Adularia-sericite epithermal gold-silver deposits in the Waihi-Waitekauri region, New Zealand. Economic Geology, v. 106, pp. 1031-1041.

Muntean, J. L., Einaudi, M. T., 2001. Porphyry-epithermal transition: Maricunga belt, northern Chile. Econ. Geol. 96: 743-772

Murphy, J.B., Gutiérrez-Alonso, G., Nance, R.D., Fernández-Suárez, J., Keppie , J.D., Quesada, C., Strachan, R.A., and Dostal, J., 2006. Origin of the Rheic Ocean: Rifting along a Neoproterozoic suture?: Geology, v. 34, p. 325 328, doi: 10.1130/G22068.1.

Murray, A. S. and Tracey, R. M., 2001. Best practice in gravity surveying. Technical Report of the Australian Geological Survey, 43 pp.

Nora, K., and Ayuso, R., 2012, Gold Deposits of the Carolina Slate Belt, Southeastern United States: Age and Origin of the Major Gold Producers. USGS, open-file report 1179.

Nystrom, P. G., Jr., 1972. Geology of the Catarrh, NW (Jefferson) Quadrangle: Unpublished M.S. thesis, Columbia, Univ. South Carolina, 49 p.

Nystrom, P. G., Jr., and Maybin, A. H., 2005. Generalized Geologic Map of South Carolina 2005. South Carolina Geological Survey.

Nystrom, P. G., Jr., Willoughby, R. H., and Price, L. K., 1991. Cretaceous and Tertiary stratigraphy of the upper Coastal Plain, South Carolina, in Horton, J. W., Jr., and Zullo, V. A. eds., The Geology of the Carolinas: Knoxville, Tennessee, The University of Tennessee Press, p. 221-240.

Oliveira, V., Matos, J., Bengala, M., Silva, N., Sousa, P., and Torres, L., 1998. Geology and geophysics as successful tools in the discovery of the Lagoa Salgada Orebody (Sado Tertiary Basin-Iberian Pyrite Belt), Grandola, Portugal: Mineralium Deposita, v. 33, p.170-187.

Palacky, G. J., 1981. The airborne electromagnetic method as a tool of geological mapping: Geophysical Prospecting, 29, 60-88. 
Pardee, J.R., and Park, C.F., Jr., 1948. Gold deposits of the southern Piedmont: U.S. Geological Survey Professional Paper 213, 156 p.

Phillips, J.D., 2007. Geosoft eXecutables (GX's) developed by the U.S. Geological Survey, Version 2.0, with notes on GX development from Fortran Code. U.S. Geological Survey, Open file, Report: 1335.

Pollock, J.C., 2007. The Neoproterozoic-Early Paleozoic Tectonic Evolution of the Peri Gondwanan Margin of the Appalachian Orogen: An Integrated Geochronological, Geochemical and Isotopic Study from North Carolina and Newfoundland [Ph.D. dissertation]: Raleigh, North Carolina State University, 208 p.

Popenoe, P., and Zietz, I., 1977. The nature of the geophysical basement beneath the Coastal Plain of South Carolina and northeastern Georgia, in Rankin, D.W., ed., Studies related to the Charleston, South Carolina, earthquake of 1886-A preliminary report: U.S. Geological Survey Professional Paper 1028, p. 119-137.

Poulsen, K.H., and Hannington, M.D., 1996. Volcanic-associated massive sulfide gold: Geological Survey of Canada, no. 8, p.183-196.

Poulsen, K.H., Robert, F., and Dubé, B., 2000. Geological classification of Canadian gold deposits: Geological Survey of Canada Bulletin 540.

Ragland, P. C., 1991. Mesozoice Igneous Rocks. In: Horton, J. W., Jr. \& Zullo, V.A. (eds), The geology of the carolinas: Carolina Geological Society fiftieth anniversary volume. Knoxville: University of Tennessee Press, p171-190

Rama Rao, C., Kishore, R. K., Pradeep Kumar, V., and Butchi Babu, B., 2011. Delineation of intra crustal horizon in Eastern Dharwar Craton - An aeromagnetic evidence. Journal of Asian Earth Sciences, 40(2), 534-541. https://doi.org/10.1016/j.jseaes.2010.10.006

Reeves, C., 2005, E-Book on Aeromagnetic Surveys: Principles, Practice and Interpretation. Retrieved March 2, 2017, from http://www.geosoft.com/news/news-releases/e-bookaeromagnetic-surveys principles-practice-and-interpretati

Reid, A.B., Allsop, J.M., Granser, H., Millett, A.J. and Somerton, I.W., 1990. Magnetic interpretation in three dimensions using Euler deconvolution. Geophysics, 55:80 $-91$.

Robert, F., 2004. Geologic footprints of gold systems, in J Muhling et al. eds., SEG 2004: Predictive Mineral Discovery Under Cover, Extended Abstracts: Centre for Global Metallogeny, The University of Western Australia Publication 33, 97-101. 
Robert, F., Brommecker, R., Bourne, B.T., Dobak, P.J., McEwan, C.J., Rowe, R.R., and Zhou, X., 2007. Models and exploration methods for major gold deposit types: Exploration 07: Fifth Decennial International Conference on Mineral Exploration, Toronto, 2007, Proceedings, p. 691-711.

Rochette, P., Jackson, M., Aubourg, C., 1992. Rock magnetism and the interpretation of anisotropy of magnetic susceptibility. Reviews of Geophysics 30 (3), 209-226.

Sacks, P.E., and Dennis, A.L., 1987. The Modoc Zone-D2 (Early Alleganian) in the EasternAppalachian Piedmont, South Carolina and Georgia. Anatomy of Alleghanian Orogeny as Seen from the Piedmont of South Carolina and Georgia. Carolina Geological Society Field Trip Guidebook. South Carolina Geological Survey, 19-34.

Salem, A., Williams, S., Fairhead, D., Ravat, D., and Smith, R., 2007, Tilt-Depth method: A simple depth estimation method using first-order magnetic derivatives. The Leading Edge, 26, 1502-1505.

Salem, A., Williams S., Fairhead J.D., Smith R. and Ravat D.J., 2008. Interpretation of magnetic data using tilt-angle derivatives, Geophysics, 73, P. L1- L10.

Scheetz, J.W., 1991, The geology and alteration of the Brewer gold mine in South Carolina: Unpublished M.Sc. thesis, Chapel Hill, University of North Carolina, $180 \mathrm{p}$.

Schmidt, R.G., 1985, High-alumina hydrothermal systems in volcanic rocks and their significance to mineral prospecting in the Carolina slate belt: U.S. Geological Survey Bulletin 1562, 59p.

Secor, D. T., Jr., 1987, Regional Overview. Anatomy of the Alleghanian Orogeny as Seen from the Piedmont of South Carolina and Georgiz Carolina Geological Society Field Trip Guidebook. South Carolina Geological Survey, 1-18.

Secor, T., and Wagener, D., 1968. Stratigraphy, structure and petrology of the Piedmont in Central South Carolina: Columbia, South Carolina, South Carolina Geological Survey, Geologic Notes, v. 12, p. 67-84.

Secor, D. T., Jr., and Snoke, W., 1978, Stratigraphy, structure, and plutonism in the CentralSouth Carolina Piedmont, in Snoke, A.W., ed., Geological Investigations of the Eastern Piedmont, Southern Appalachians: Carolina Geological Society Guidebook for 1978 Annual Meeting, p. 43-63.

Secor, T., and Snoke, A.W., 2002, Geologic map of the Batesburg and Emory Quadrangles, Lexington and Saluda counties, South Carolina. Boulder, Colorado, Geological Societyof America Map and Chart Series MCH 091, p.32 
Secor, D. T., Jr., Samson, L., Snoke, W., and Palmer, R., 1983, Confirmation of the Carolina Slate Belt as an Exotic Terrane: Science, v. 221, p. 649-651.

Secor, D.T., Jr., Snoke, A.W., Bramlett, K.W., Costello, O.P., and Kimbrell, O.P., 1986a. Character of the Alleghanian orogeny in the Southern Appalachians: Part I. Alleghanian deformation in the eastern Piedmont of South Carolina: Geological Society of America Bulletin, v. 97, no. 11, p. 1319-1328, doi: 10.1130/0016 7606(1986)97<1319:COTAOI>2.0.CO;2.

Secor, D.T., Jr., Snoke, A.W., and Dallmeyer, R.D., 1986b. Character of the Alleghanian orogeny in the Southern Appalachians: Part III. Regional tectonic relations: Geological Society of America Bulletin, v. 97, no. 11, p. 1345-1353, doi: 10.1130/0016 7606(1986)97<1345:COTAOI>2.0.CO;2.

Sillitoe, R. H., 1995. The influence of magmatic hydrothermal models on exploration strategies for volcano-plutonic arcs: In: Thompson, J. F. H. (Ed.), Magmas, fluids and ore deposits, Mineralogical Association of Canada Short Courses, v. 23, p. 511-525.

Sillitoe, R.H., Hannington, M.D., and Thompson, J.F.H., 1996. High Sulfidation deposits in the volcanogenic massive sulfide environment: Economic Geology, 91, 204 212.

Shah, A.K., Bern, C.R. Van Gosen, B.S., Daniels, D.L., Benzel, W.M., Budahn, J.R., Ellefsen, K.J., Karst, A., and Davis, R., 2017. Rare earth mineral potential in the southeastern U.S. Coastal Plain from integrated geophysical, geochemical, and geological approaches, Geological Society of America Bulletin, doi:10.1130/B31481.1.

Sharma, P. V., 1997. Environmental and Engineering Geophysics.Cambridge University Press. Page 17.

Snider, J., Patterson, E., Gochnour, L., Marek, J., and Burkhalter, C., 2014. Haile Gold Mine Project, NI 43-101 Technical Report.

Snipes, D. S., Fallaw, WC., Price, Van, Jr., Cumbest, R.J., 1993. The Pen Branch fault Documentation of late Cretaceous-Tertiary faulting in the Coastal plain of South Carolina: Southeastern Geology, v. 33, no.4,p.195-218.

Snoke, A., Secor,T., Jr., and Metzgar, C., 1977. Batesburg-Edgefield catalastic zone-a fundamental tectonic boundary in the South Carolina Piedmont: Geological Societyof America Abs. with Programs, v. 9, no. 2, p. 185-186.

Spector, A., and Grant, F. S., 1970. Statistical models for interpretation of aeromagnetic data, Geophysics, 35: 293 - 302. 
Speer, J. A., 1981. Petrology of cordierite and almandine bearing granitoid plutons of the Southern Appalachian piedmont, U.S.A. Canadian Mineralogist, vol. 19, pp.35-46.

Speer, J. A., and Hoff, K., 1997. Elemental composition of Alleghanian granitoid plutons of the southern Appalachians, in Sinha, A. K., Whalen J. B., and Hogan, J. P., eds., The nature of magmatism in the Appalachians orogen: Boulder, Colorado, Geological Society of America Memoir 191, p. 287-308.

Speer, W.E., and Maddry, J.W., 1993, Geology and recent discoveries at the Haile gold mine, Lancaster County, South Carolina: South Carolina Geology, v. 35, p. 9-26.

Speer, J. A., Becker, S. W., and Farrar, S.S., 1980. Field relations and petrology of the post metamorphic, coarse gained granitoids and associated rocks of the southern Appalachian Piedmont, Proceedings 'Caledonides in the U.S.A.," edited by D. R. Wones, Mere. 2, pp. 137-148, Dep. Geol. Sci., Va. Polytech. Inst. and State Univ., Blackburg.

Spence, W.H., Worthington, J.E., Jones, E.M., and Kiff, I.T., 1980, Origin of the gold mineralization at the Haile mine in Lancaster County, South Carolina: Mining Engineering, v. 32, p. 70-73.

SRK Consulting, 2010. Arseneau, G., and MacIntyre, D., Clear Lake Zinc-Lead-Silver Deposit Yukon. Project Number 2CC035.000

SRK Consulting, 2017. Carr D., van Brunt B., Jory J., Howw P., Poeck J., Osbom J., Moore J., Tinucci J., Swanson B., Kinakin D., Malensek G., Bird D., Stryhas B., and Prosser B., NI 43-101 Technical Report: Feasibility Study, Haile Gold Mine, Lancaster County, South Carolina, 319 pp.

Takakura S., Koji Nakada K., and Murakami H., 2012. Complex resistivity measurements of sericite. Geophysical Exploration, 66(2), p:119-125.

Tarling, D.H., Hrouda, F., 1993. The Magnetic Anisotropy of Rocks. Chapman \& Hall, London. 217 pp.

Telford, W. M.,Geldart, L. P., Sheriff, R. E., Keys, D. A., 1976, Applied Geophysics, Cambridge University Press.

Telford, W.M., Geldart, L.P., Sheriff, R.E., 1990, Applied Geophysics Second Edition, Cambridge University Press, New York, 744 p.

Thompson, D.T., 1982. EULDPH; a new technique for making computer-assisted depth estimates from magnetic data. Geophysics 47 (1), 32-38. 
Tomkinson, M.J., 1988, Gold mineralization in phyllonites at the Haile mine, South Carolina: Economic Geology, v. 83, p. 1392-1400.

Tuten, T., 2013. Geophysical model of granite intrusives surrounding the Haile Gold Mine, Lancaster County, SC using high resolution gravity data, Senior thesis, University of South Carolina, 29 p.

Verduzco, B., Fairhead, J. D., Green, C. M., MacKenzie, C., 2004, New insights into magnetic derivatives for structural mapping: The Leading Edge, 23, 116-119.

Warner, R, D., and Wasilewski P. J., 1990. Magnetic petrology of eastern North America diabases, I. Olivine-normative dikes from western South Carolina. Earth and Planetary Science Letters, 98, 340-359

White, N.C., 1991. High sulfidation epithermal gold deposits: Characteristics, and a model for their origin. Geo/. Surv. Japan Report 227, 920

Whitehead, N., 2010. Montaj Grav/Mag Interpretation, tutorial and user guide, Geosoft Incorporated.

Whitenhead, N., and Musselman, C., 2011. Montaj MAGMAP filtering, Geosoft Incorporated.

Worthington, J.E., and Kiff, I.T., 1970, A suggested volcanogenic origin for certain gold deposits in the slate belt of the Carolina piedmont: ECONOMIC GEOLOGY, v. 65 , p. $529-537$.

Worthington, J. E., Kiff, I. T., Jones, E. M. and Chapman, P. E., 1980, Applications of the hot springs or fumarolic model in prospecting for lode gold deposits: Mining Engineering, v. 32, p. 73-79.

Wynn, J., and Luce, R., 1984. Geophysical methods as mapping tools in a strata-bound gold deposit; Haile Mine, South Carolina slate belt. Economic Geology 79(2):382-388.

Zahra, H., and Oweis, H., 2016. Application of high-pass filtering techniques on gravity and magnetic data of the eastern Qattara Depression area, Western Desert, Egypt. NRIAG Journal of Astronomy and Geophysics, V. 5, P.106-123.

Zwaschka, M. and Scheetz, J. W., 1995, Detailed Mine Geology of the Brewer Gold Mine, Jefferson, South Carolina: Society of Economic Geologists Guidebook Series, v. 24, p.95-141. 


\section{APPENDIX A}

\section{COPYRIGHT PERMISSION FOR CHAPTER 2}

\section{Earth, Ocean and Environment}

Saad Alarifi <salarifi@geol.sc.edu>

\section{Re: Permission to reprint [190911-000811]}

Researcher Support <support@elsevier.com>

Reply-To: Researcher Support <support@elsevier.com>

To: salarif@geol.sc.edu

Dear Dr Alanifi,

Article reference: APPGEO3737

Thank you for your query regarding using your article in your thesis.

I can confirm that that authors can use their articles, in full or in part, for a wide range of scholarly, non-commercial purposes one of which is inclusion in a thesis or dissertation. See the following link for further information on this

https://uww.elsevier.com/about/our-business/policies/copyright/personal-use

As you will be able to see from the above link, our policy is to allow authors to use their work in their thesis or dissertation (provided that this is not to be published commercially).

Therefore, I can confirm that you can make it publicly available on your university web site/repository for non- commercial use.

If you require further clarification please contact permissions@elsevier.com who will be able to further help you on this.

I hope this helps.

If I can be any further assistance, please do not hesitate to let me know.

Kind regards,

Melca Ebe

Researcher Support

ELSEVIER

Find out some simple ways to share your research data, including features that are directly available when you submit your research article to an Elsevier journal.

For assistance, please visit our Customer Support site where you can search for solutions on a range of topics and find answers to frequently asked questions.

From: Saad Alarifi

Date: 11/09/2019 12.30 AM

I intend to included "Article reference:APPGEO_3737

DOI information: 10.1016/.jappgeo.2019.03.011

Title :Gravity, aeromagnetic and electromagnetic study of the gold and pyrite mineralized zones in the Haile Mine area, Kershaw, South Carolina.

Joumal of Applied Geophysics" as part of my PhD dissertation and I need a permission to reprint or copyright permission from the APPGEO as university request. 